\title{
DOENÇA PERIODONTAL INFLAMATÓRIA INDUZIDA POR LIGADURA: CARACTERIZAÇÃO MICROSCÓPICA E ESTUDO DA PRESENÇA DE MASTÓCITOS E DAS ENZIMAS ÓXIDO NÍTRICO SINTASE INDUZÍVEL (iNOS) E METALOPROTEINASES -2 E -9
}

Camila de Oliveira Rodini

\begin{abstract}
Dissertação apresentada à Faculdade de Odontologia de Bauru, da Universidade de São Paulo, como parte dos requisitos para obtenção do título de Mestre em Odontologia, área de Patologia Bucal.
\end{abstract}

(Edição Revisada) 


\title{
DOENÇA PERIODONTAL INFLAMATÓRIA INDUZIDA POR LIGADURA: CARACTERIZAÇÃO MICROSCÓPICA E ESTUDO DA PRESENÇA DE MASTÓCITOS E DAS ENZIMAS ÓXIDO NÍTRICO SINTASE INDUZÍVEL (iNOS) E METALOPROTEINASES -2 E -9
}

\section{Camila de Oliveira Rodini}

\begin{abstract}
Dissertação apresentada à Faculdade de Odontologia de Bauru, da Universidade de São Paulo, como parte dos requisitos para obtenção do título de Mestre em Odontologia, área de Patologia Bucal.
\end{abstract}

(Edição Revisada)

Orientadora: Prof ${ }^{a}$. Dr ${ }^{\text {a }}$. Vanessa Soares Lara 


\begin{tabular}{|l} 
Rodini, Camila de Oliveira \\
Doença periodontal inflamatória induzida por ligadura: \\
Caracterização microscópica e estudo da presença de \\
mastócitos e das enzimas óxido nítrico sintase induzível \\
(iNOS) e metaloproteinases -2 e -9 / Camila de Oliveira \\
Rodini - Bauru, 2005. \\
149p. :il.; 31cm. \\
Dissertação. (Mestrado) - Faculdade de Odontologia de \\
Bauru. USP. \\
Orientadora: Profa. Dra. Vanessa Soares Lara \\
\end{tabular}

Autorizo, exclusivamente para fins acadêmicos e científicos, a reprodução total ou parcial desta tese, por processos fotocopiadores e outros meios eletrônicos.

Assinatura:

Bauru, 04 de abril de 2005.

Aprovado pelo Comitê de Ética em Pesquisa da Faculdade de Odontologia de Bauru, USP.

Protocolo: 008/2003

Data: 07 de maio de 2003 


\section{Camila de Oliveira Rodini}

Nascimento

$1998-2001$

2002

$2003-2005$

06 de fevereiro de 1979

Curso de Graduação em Odontologia pela Faculdade de Odontologia de Bauru, Universidade de São Paulo Bauru - S.P.

Curso de Aperfeiçoamento em Ortodontia Preventiva e Interceptiva I promovido pela Sociedade de Promoção Social do Fissurado Lábio-palatal (PROFIS)- Bauru - S.P. Mestrado em Odontologia, Área de concentração Patologia Bucal, na Faculdade de Odontologia de Bauru USP. 
"Se não houver frutos, valeu a beleza das flores.

Se não houver flores, valeu a sombra das folhas. Se não houver folhas, valeu a intenção da semente."

Henfil 
Dedico este trabalho a todos que, de uma forma ou outra, me apoiaram a trilhar este caminho, principalmente aos meus pais, Elaine e Bruno, pessoas ao mesmo tempo tão diferentes, mas comuns na essência dos valores, à minha irmã Carol, que me orgulha a cada dia, ao meu querido Eduardo, que me completa, e a toda a minha família, pelo amor, pelo exemplo de caráter e pela segurança. 


\section{AGRADECIMENTOS PESSOAIS}

Especialmente à querida professora Vanessa Soares Lara, minha orientadora desde a graduação até o presente trabalho, agradeço pelo constante estímulo, enorme confiança e dedicação, mesmo em momentos às vezes difíceis e em outros tão especiais. A construção da nossa amizade foi inevitável, extremamente prazerosa e verdadeira. Estendo o agradecimento ao Vinícius, pelo carinho e pela simpatia.

A todos que contribuíram, e muitos que contribuirão sempre, com meu crescimento profissional e pessoal, e direta ou indiretamente com o desenvolvimento e a finalização deste trabalho, dedico meus agradecimentos:

Aos demais Professores do Departamento de Estomatologia, Disciplina de Patologia Bucal: Prof. Dr. Alberto Consolaro, Prof. Dr. Luís Antônio de Assis Taveira e Profa. Dra. Denise Tostes Oliveira;

Aos colegas e amigos funcionários e ex-funcionários da Disciplina de Patologia Bucal: Fátima Aparecida Silveira, Maria Cristina Carrara Felipe, Bernadete Aparecida Alves Camargo, Valdir João Afonso, ao aprendiz Osiel Pereira Cabrera, e ao perseverante Richerland Medeiros, pelo carinho, disponibilidade e eficiência com que sempre me auxiliaram;

À Aline, por sua graciosidade, sinceridade e energia sempre contagiante. Uma amiga fiel, de quem muito me orgulho e que merece colher somente bons frutos daquilo que mais cultiva: a amizade. Seu caminho será sempre repleto de sucesso! 
Aos valiosos amigos que conheci no Departamento de Patologia: Lidiane, Luciana, Renato, Rosário, João, Jussara, Tarcília, Patrícia, Amanda e Fatiminha, com quem compartilho momentos de alegria e incentivo mútuo, e aos colegas do Curso de Mestrado em Patologia Bucal: Bethânia, Renata Falchete, Renata Consolaro e Thiago;

Um agradecimento especial à Lidiane, companheira desde o início deste trabalho e que, junto com o Ricardo, se transformaram em grandes amigos;

À Tânia Mary Cestari, sempre disposta a ajudar. Fico feliz com o reconhecimento de seu valor e desejo-lhe cada vez mais sucesso!

À Thais Marchini e à Ligia Schimidt, pela ajuda com as fotos clínicas apresentadas neste trabalho;

Ao Prof. Dr. José Roberto Pereira Lauris e à Profa. Dra. Sandra Lia do Amaral, pela colaboração na realização das análises estatísticas;

Aos funcionários do Biotério da Faculdade de Odontologia de Bauru USP, em especial nas pessoas de Erasmo Gonçalves da Silva e Luiz Carlos da Silva, colaboradores no andamento das pesquisas e na luta para se conseguir um espaço mais organizado e adequado para o condicionamento e manipulação dos animais;

Ao Prof. Dr. Carlos Ferreira dos Santos e ao amigo Thiago José Dionísio, pela colaboração direta e imprescindível na realização dos experimentos de RT-PCR, todos realizados no laboratório da Disciplina de Farmacologia da Faculdade de Odontologia de Bauru -USP, bem como pelo constante estímulo, pela generosidade e pelos ensinamentos valiosos;

Ao Prof. Dr. Jesus Carlos Andreo, da Disciplina de Anatomia da Faculdade de Odontologia de Bauru -USP, e à Dra. Elza Torres, do setor de 
Imunogenética do Hospital de Reabilitação de Anomalias Craniofaciais -USP, pela simpatia com que nos permitiram a utilização das dependências de seus laboratórios e de alguns equipamentos;

Ao Prof. Dr. Fernando de Queiróz Cunha, que gentil e prontamente cedeu as dependências do Laboratório de Farmacologia da Faculdade de Medicina de Ribeirão Preto -USP, para a fotodocumentação dos experimentos de RT-PCR realizados no presente trabalho.

Aos funcionários da Seção de Pós-graduação: Ana Letícia Palombo Momesso, Giane Tenório Quintela e Maria Margareth Pereira Mokarzel, pelo carinho e ajuda;

Aos amigos André, Andréia e Marina, sempre presentes apesar de distantes, com quem compartilho muitas decisões. É muito gratificante participar das vitórias de vocês!

À Claudinha, pelos momentos de descontração e pela sincera amizade;

À Amélia, pelo aconchego da comida quentinha e da casa cheirosa e pelo carinho;

Aos meus queridos avós, tios e primos, pela alegria de tê-los por perto;

À minha mãe, sem dúvida minha maior incentivadora e conselheira em tudo. Admiro sua versatilidade, bondade, humildade, perseverança, competência e alegria de viver. Agradeço pelo seu amor incondicional!

Ao meu pai, uma pessoa pura e de caráter inquestionável, que demonstra de modo particular todo seu imenso amor. Agradeço pela segurança que você sempre nos proporcionou e pelo exemplo de bondade e honestidade. 
À Carol, minha irmã querida que sempre esteve ao meu lado, mas que nesses últimos anos está crescendo longe de nós. Por um lado é muito difícil ver seu quarto vazio, embora eternamente bagunçado, mas por outro é extremamente gratificante perceber sua maturidade! Serei sempre sua melhor amiga...

Ao Dú, que também me faz sofrer pela distância, mas que compensa tudo pelo seu amor, sua cumplicidade e alegria. Agradeço pela convivência deliciosa desses anos e dos que ainda virão, certa de que sempre estaremos verdadeiramente um ao lado do outro! 


\section{AGRADECIMENTOS INSTITUCIONAIS}

À Fundação de Amparo à Pesquisa do Estado de São Paulo (FAPESP: Processos 01/01964-6 e 02/09380-6), provedora dos recursos utilizados para a compra da maioria dos reagentes utilizados no presente trabalho;

Ao Conselho de Aperfeiçoamento de Pessoal de Nível Superior (CAPES), pela concessão de minha bolsa de mestrado e pela possibilidade de se obter financiamento via Programa de Apoio à Pós-Graduação (PROAP);

À Faculdade de Odontologia de Bauru, Universidade de São Paulo, por quem tenho muito carinho e respeito, na pessoa de sua excelentíssima Diretora, Profa. Dra. Maria Fidela de Lima Navarro;

À Comissão de Pós-Graduação da Faculdade de Odontologia de Bauru, na pessoa do Presidente, Prof. Dr. José Carlos Pereira;

Ao Departamento de Estomatologia da Faculdade de Odontologia de Bauru, na pessoa do Chefe Prof. Dr. Luis Eduardo Chinelatto. 


\section{SUMÁRIO}

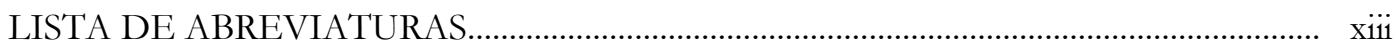

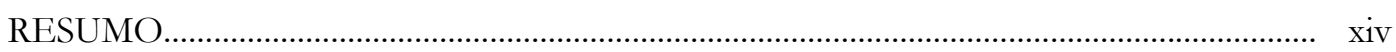

1 INTRODUÇÃO E SÍNTESE BIBLIOGRÁFICA....................................................... 1

1.1 Doença periodontal inflamatória............................................................................... 1

1.2 Mastócitos na doença periodontal inflamatória............................................................. 5

1.3 Metaloproteinases e óxido nítrico na doença periodontal inflamatória ................... 8

$1.4 \quad$ Aspectos fisiológicos dos tecidos periodontais............................................................. 15

1.5 Doença periodontal inflamatória experimental........................................................ 21

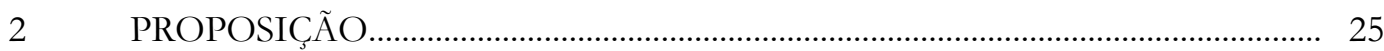

3 MATERIAL E MÉTODOS................................................................................ 26

3.1 Animais e protocolo de indução da doença periodontal inflamatória........................ 26

3.2 Análise macroscópica clínica..................................................................................... 31

3.3 Análise microscópica morfológica dos grupos controle e experimental................... 31

3.4 Análise quantitativa dos mastócitos.......................................................................... 33

3.5 Análise por RT-PCR .................................................................................... 34

3.5.1 Extração de RNA total de tecidos gengivais............................................................ 34

3.5.2 Tratamento do DNA extraído com DNase.............................................................. 35

3.5.3 Quantificação do RNA total................................................................................. 35

3.5.4 Avaliação da qualidade do RNA total...................................................................... 36

3.5.5 Reação de RT-PCR........................................................................................... 36

3.5.6 PCR e detecção dos produtos amplificados em gel de agarose................................ 37

3.5.7 Análise da intensidade da expressão de RNA mensageiro (RNAm)........................ 39

3.6 Análise estatística.............................................................................................. 39

4 RESULTADOS....................................................................................... 41

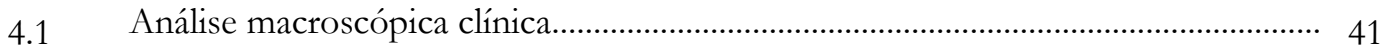

4.2 Análise microscópica das amostras submetidas à desmineralização em EDTA 44

4.2.1 Tecidos periodontais normais................................................................................... 44

4.2.2 Tecidos periodontais submetidos ao progressivo acúmulo de placa 51 dentobacteriana por meio da colocação da ligadura...

4.3 Análise microscópica morfológica das amostras de tecido gengival......................... 73

4.3.1 Tecidos periodontais normais............................................................................. 73 
4.3.2 Tecidos periodontais submetidos ao progressivo acúmulo de placa dentobacteriana por meio da colocação da ligadura..

4.4 Análise quantitativa dos mastócitos........................................................................... 80

4.5 Análise qualitativa dos mastócitos............................................................................... 89

4.5.1 Tecidos periodontais normais............................................................................ 89

4.5.2 Tecidos periodontais submetidos ao progressivo acúmulo de placa dentobacteriana por meio da colocação da ligadura...

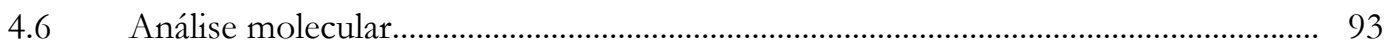

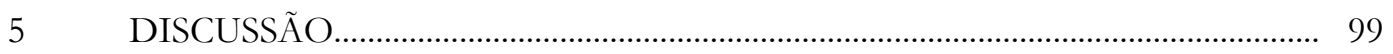

5.1 Indução experimental da doença periodontal inflamatória em ratos, por meio de ligadura..

5.2 Correlações entre doença periodontal inflamatória humana e a experimental......... 102

5.3 Comparação entre as diferentes amostras obtidas....................................................... 108

5.4 MMPs na doença periodontal inflamatória experimental......................................... 110

5.5 iNOS na doença periodontal inflamatória experimental......................................... 117

5.6 Presença de mastócitos na doença periodontal inflamatória experimental.............. 121

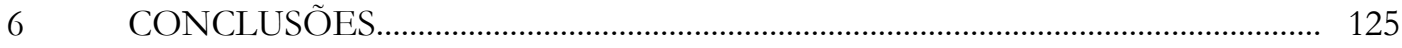

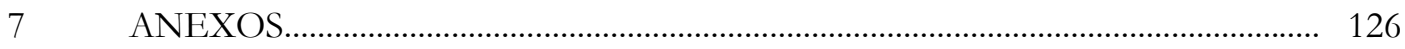

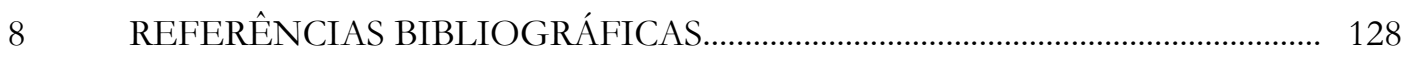

$9 \quad$ ABSTRACT 


\section{LISTA DE ABREVIATURAS}

bFGF Basic Fibroblastic Growth Factor (Fator de Crescimento Fibroblástico Básico)

cDNA DNA complementar

d.p. Desvio-padrão

eNOS Endotelial Nitric Oxide Synthase (Óxido nítrico sintase endotelial)

HE Hematoxilina e Eosina

IFN Interferon

IL Interleucina

iNOS Inducible Nitric Oxide Synthase (Óxido nítrico sintase induzível)

LPS Lipopolissacarídeos

min minutos

$\mathrm{mL} \quad$ mililitros

MMP Metalloproteinase (Metaloproteinase)

MN Mononucleares

nNOS Neural Nitric Oxide Synthase (Óxido nítrico sintase neuronal)

NO Nitric Oxide (Óxido nítrico)

${ }^{\circ} \mathrm{C} \quad$ Graus Celsius

$P \quad$ Probabilidade

PCR Polimerase Chain Reaction (Reação em Cadeia da Polimerase)

proMMP Pró-metaloproteinase

RNAm RNA mensageiro

RT Reverse Transcription (Transcrição Reversa)

RT-PCR Reverse Transcription Polimerase Chain Reaction (Reação em Cadeia da Polimerase precedida por Transcrição Reversa)

s segundos

TGF Transforming Growth Factor (Fator Transformador do Crescimento)

Th Thelper (Linfócito T auxiliar)

TIMP Tissue Inhibitor of Metalloproteinase (Inibidor Tecidual de Metaloproteinase)

TNF Tumor Necrosis Factor (Fator de Necrose Tumoral) 


\section{RESUMO}

A doença periodontal inflamatória envolve mecanismos imunopatológicos e inflamatórios contra microrganismos da placa dentobacteriana, sendo que diversas células, tanto residentes quanto inflamatórias, e mediadores químicos participam ativamente da resposta do hospedeiro. O presente trabalho teve como objetivo caracterizar o modelo experimental da doença periodontal inflamatória induzida por ligadura em ratos, com ênfase na avaliação clínica e microscópica, bem como no estudo quantitativo dos mastócitos e da presença de RNA mensageiro (RNAm) codificador das enzimas óxido nítrico sintase induzível (iNOS) e metaloproteinases (MMPs) -2 e -9. Para este fim, as amostras correspondentes foram obtidas em diferentes períodos de indução da doença periodontal inflamatória experimentalmente induzida $(1,3,7,14,28,42$ e 56 dias ou 1, 3, 7, 14 e 30 dias) e avaliadas microscopicamente por meio das colorações de hematoxilina-eosina e azul de toluidina, bem como semi-quantitativamente por meio de Reação em Cadeia da Polimerase precedida por Transcrição Reversa (RT-PCR). Para fins comparativos, foram utilizadas amostras de tecido gengival normal do mesmo animal. Microscopicamente, observou-se exuberante presença de polimorfonucleares (PMNs) nos tecidos afetados pela doença periodontal inflamatória, especialmente nos períodos inicias. Detectou-se ainda a expressão aumentada de RNAm para MMP-9 apenas nos tecidos afetados pela doença periodontal nos períodos de 3 e 7 dias, porém não se observou aumento estatisticamente significativo na expressão de RNAm para MMP-2 em nenhuma das comparações analisadas. Com relação à iNOS, a expressão de seu RNAm foi maior nos tecidos doentes quando comparados com os tecidos gengivais controle no período de 3 dias, assim como nos tecidos afetados pela doença periodontal no período de 3 dias ao se comparar com os tecidos doentes aos 7 dias após a indução. Ainda, o número de mastócitos $/ \mathrm{mm}^{2}$ na região adjacente aos epitélios sulcular e juncional, bem como na área de inserção conjuntiva, apresentou-se diminuído na doença periodontal inflamatória experimentalmente induzida em ratos, com relação aos tecidos gengivais saudáveis, tanto no lado vestibular quanto no lingual. Nossos resultados sugerem que a doença periodontal experimentalmente induzida em ratos caracteriza-se por lesões inflamatórias com predomínio de células PMNs e áreas de reabsorção óssea alveolar desde as primeiras 24 horas após a indução, porém sem progressão para um infiltrado 
inflamatório linfoplasmocitário organizado focalmente que caracteriza a doença humana. Provavelmente, a MMP-9 e o óxido nítrico (NO) têm participação na evolução e patogênese da doença periodontal experimentalmente induzida por ligadura, incluindo destruição tecidual e perda óssea alveolar. De forma contrária, os mastócitos parecem ter limitada participação na referida doença, não constituindo, provavelmente, fonte significativa da iNOS e da MMP-9. 


\section{1- INTRODUÇÃO E SÍNTESE BIBLIOGRÁFICA}

\section{1- Doença Periodontal Inflamatória}

A saúde periodontal pode ser considerada um estado de equilíbrio, no qual microrganismos potencialmente patogênicos coexistem com o hospedeiro no microambiente bucal, não resultando em danos irreparáveis tanto para as bactérias como para os tecidos periodontais do hospedeiro ${ }^{71}, 100$. No entanto, alguns fatores disparam o início da doença periodontal inflamatória (doença gengival induzida por placa dentobacteriana e periodontite crônica) ${ }^{6}$, interferindo, ainda, na determinação de sua gravidade e perpetuação.

As doenças periodontais inflamatórias incluem diversas alterações inflamatórias tanto nos tecidos de proteção (gengivite ou doença gengival induzida por placa dentobacteriana) quanto de sustentação dos dentes (periodontite crônica), sendo caracterizadas, em suas fases mais avançadas, especialmente pela destruição do ligamento periodontal, perda da crista óssea alveolar, migração apical do epitélio juncional e formação de bolsas periodontais ${ }^{71}$ 125, 234. O agente etiológico primário destas doenças é a placa dentobacteriana, composta principalmente por bactérias colonizadoras da superfície dentária, inicialmente gram-positivas, dispostas sob a forma de biofilmes microbianos. Esta organização confere condições favoráveis ao desenvolvimento microbiano, uma vez que atuam como barreira, retendo substâncias produzidas pelas próprias bactérias e, ao mesmo tempo, protegendo-as de fatores de defesa do organismo hospedeiro e de agentes antimicrobianos externos $40,83,126$. A partir do crescente acúmulo de microrganismos na placa dentobacteriana na margem gengival, alterações no microambiente do biofilme microbiano possibilitam a colonização de bactérias gram-negativas. Então, os componentes típicos desta espécie, como os lipopolissacarídeos (LPS), surgem e supostamente interagem com 
receptores de superfície dos queratinócitos do epitélio sulcular, atingindo o tecido conjuntivo, onde entram em contato com fibroblastos, células endoteliais e leucócitos. Clinicamente, essa fase inicial reflete alterações inflamatórias restritas ao periodonto de proteção, caracterizadas como vermelhidão e inchaço da margem gengival, sangramento quando provocado, alterações no contorno gengival, bem como perda de adesão tecidual e aumento do fluxo do fluido gengival, no intuito de diluir e eliminar o agressor. Estabelece-se, então, o quadro de gengivite induzida por placa dentobacteriana, que não envolve perda de inserção periodontal e é reversível perante a remoção da referida placa ${ }^{4,10,94,121}$. Microscopicamente, as alterações teciduais observadas na gengivite induzida por placa dentobacteriana incluem proliferação da camada basal do epitélio juncional, levando à migração celular apical e lateral, vasculite dos vasos sangüíneos adjacentes ao epitélio juncional, destruição progressiva de fibras colágenas, alterações citopatológicas nos fibroblastos residentes e infiltrado inflamatório/imune progressivo ${ }^{164}$.

A persistência dos biofilmes microbianos em íntima proximidade aos tecidos periodontais humanos, possibilitando contínuo estímulo antigênico, torna a resposta inflamatória, inicialmente aguda, na qual predominam alterações vasculo-exsudativas e degradação de colágeno, em lesão crônica, com proliferação do epitélio juncional abaixo da junção cemento-esmalte, formando-se uma bolsa periodontal, além de contínua destruição do colágeno, ativação de fibroblastos e fagócitos, acúmulo de células polimorfonucleares (PMNs) nos epitélios juncional e da bolsa periodontal, denso infiltrado inflamatório mononuclear (MN), predominantemente linfoplasmocitário, e perda de suporte dentário caracterizado pela reabsorção óssea alveolar. Dessa forma, a periodontite crônica pode ser definida como uma doença tipicamente crônica e continuamente progressiva, que apresenta repentinos indícios de atividade ${ }^{94,}$ 99, 164, 206. A constante modificação do microambiente local possibilita o 
desenvolvimento de uma placa dentobacteriana subgengival, caracterizada por uma microbiota principalmente gram-negativa anaeróbia e de espiroquetas, que constituem as principais bactérias periodontopatogênicas, como Actinobacillus actinomycetemcomitans, Phorphyromonas gingivalis, Prevotella intermedia e Fusobacterium nucleatum ${ }^{51,52,110}$. O desenvolvimento de uma microbiota periodontopatogênica e a continuidade do acúmulo de placa dentobacteriana resultam em uma grande quantidade de produtos microbianos; esta intensa carga antigênica no sulco gengival, por sua vez, ocasiona aumento marcante na dimensão da resposta do hospedeiro.

A partir da demonstração da presença de plasmócitos produtores de imunoglobulinas nos tecidos gengivais de pacientes com doença periodontal inflamatória ${ }^{29}$, obteve-se a primeira evidência direta da participação de mecanismos imunes adaptativos na patogênese da doença. Desde então, vários estudos tendem a confirmar a hipótese de que há uma alteração na população celular presente na doença periodontal inflamatória; uma mudança de gengivite para periodontite envolveria uma substituição de uma lesão predominantemente rica em células $\mathrm{T}$ para uma lesão abundante em células B/plasmócitos 69, 70, 198. Estudos relatam, ainda, a supressão de linfócitos por bactérias periodontopatogênicas, provavelmente a partir da indução da ativação de células $\mathrm{CD}^{+}$. Adicionalmente, na transição de gengivite para periodontite, muitos autores relatam uma diminuição da proporção de células $\mathrm{CD}^{+}$com relação às células $\mathrm{CD} 8^{+}$. Pode-se sugerir, então, que na doença periodontal inflamatória há um desequilíbrio imunorregulatório local, porém tanto células $\mathrm{T}$ quanto $\mathrm{B}$ encontram-se presentes $41,69,161,218,221,238$. Provavelmente, outras células como os mastócitos participam da ativação dos linfócitos. Atualmente, há um crescente alerta para as interações potenciais entre mastócitos e outros componentes do sistema imune, contribuindo na modulação dos eventos celulares e humorais dos mecanismos de defesa do hospedeiro contra infecções bacterianas 228,231 e, 
assim, provavelmente participando da patogênese de condições inflamatórias como a doença periodontal inflamatória.

Enquanto a presença de bactérias periodontopatogênicas e a inflamação que elas provocam são essenciais para a progressão da doença periodontal inflamatória, fatores de risco ambientais, como vício de fumar, estresse psicológico e doenças sistêmicas como diabetes, modificam a resposta do hospedeiro e podem ser os principais determinantes da enorme variação com relação à suscetibilidade. Esses fatores podem alterar os mecanismos patológicos pelos quais as bactérias causam inflamação e, conseqüentemente, modificar a progressão da doença, sua gravidade e seu efeito $^{167}$. Ainda, a contribuição relativa de fatores genéticos, como polimorfismos em receptores de células fagocíticas ${ }^{192}$ e de citocinas, como Fator de Necrose Tumoral alfa (TNF-a)65, 201, Interleucina-1 (IL-1)79, 111 e Interleucina-10 (IL-10)195, têm sido sugeridos como significantes na determinação da suscetibilidade a infecções bacterianas relacionadas à doença periodontal inflamatória e sua gravidade.

Embora a doença periodontal inflamatória resulte, primariamente, de uma resposta inflamatória à presença de bactérias na placa dentobacteriana, a suscetibilidade inata do paciente determina $o$ resultado final do processo da doença. Então, é a natureza da resposta inflamatória que determina a característica destrutiva da doença. Com o aumento da presença de bactérias, seus produtos interagem com o epitélio gengival para induzir a expressão de moléculas de adesão e a produção de citocinas pró-inflamatórias (IL-1, TNF- $\alpha$, Interferon-gama ou IFN- $\gamma$, Fator de Crescimento Fibroblástico básico ou bFGF), quimiocinas e enzimas (Óxido Nítrico Sintase induzível ou iNOS e Metaloproteinases ou MMPs) 8, 23, 24, 37, 69, $71,91,141,142$. 


\section{2- Mastócitos na Doença Periodontal Inflamatória}

$\mathrm{Na}$ doença periodontal inflamatória humana, a destruição tecidual tem sido relacionada com a liberação de LPS e enzimas que atuam diretamente sobre a matriz extracelular, e com populações celulares residentes e migrantes $23,24,165,168,199,235$. Entre as células encontradas nos tecidos periodontais, os mastócitos têm sido observados tanto no periodonto normal quanto inflamado, em diferentes quantidades e em vários locais7, 33, 81, 98, 183, 200, 229. Então, uma possível resposta do hospedeiro que implica na destruição periodontal pode envolver a participação dos mastócitos ${ }^{98}$. Muitos estudos têm proposto um papel importante dos fatores liberados por estas células na destruição tecidual presente na doença periodontal inflamatória7, 19, 73, 98, 154, 157, 159, 217; entretanto, a real contribuição desses fatores durante a progressão da doença periodontal permanece desconhecida ${ }^{98,217}$.

Os mastócitos são células residentes do tecido conjuntivo, localizadas próximas aos vasos sangüíneos e nervos. Após serem ativados, liberam seus grânulos ricos em mediadores químicos como histamina, proteoglicanas, proteases, bFGF, NO, MMPs, fosfatase ácida e citocinas, dentre elas os interferons (IFN), o TNF- $\alpha$ e as interleucinas (IL) ${ }^{109,} 145,174-6,217$, 236, 237. Esta grande variedade de mediadores farmacológicos ativos desempenha papel importante tanto em reações de hipersensibilidade quanto em processos inflamatórios, diferindo em suas potencialidades e atividades biológicas. Portanto, os mastócitos podem influenciar significantemente respostas IgE dependentes ou independentes, estendendo seu potencial de células efetoras pró-inflamatórias para componentes reguladores do sistema imune, contribuindo, desta forma, para o desenvolvimento e amplificação de respostas inflamatórias específicas e inespecíficas $66,78,81,145,203,217$.

CARRANZA \& CABRINI33, em 1955, foram os pioneiros a pesquisar a presença de mastócitos em doença periodontal inflamatória 
humana, observando um grande número de mastócitos tanto em tecido gengival normal quanto em gengivite crônica marginal. SANTOS193, em 1961, estudou, além da presença de mastócitos nas doenças periodontais inflamatórias humanas, suas características morfológicas peculiares e sua localização, encontrando um aumento proporcional de mastócitos com o aumento da intensidade do infiltrado inflamatório. BARNETT15, 16, em 1973 e em 1974, observou a presença de mastócitos no interior do revestimento epitelial de bolsas periodontais, apresentando características morfológicas sugestivas de síntese e liberação do conteúdo de seus grânulos para o espaço extracelular. Este autor relatou ainda uma distribuição difusa de mastócitos por todo o tecido conjuntivo, além de íntima relação destas células com fibras colágenas e células endoteliais, em biópsias humanas de doença periodontal inflamatória. A partir dessas observações, sugeriu a hipótese de que, em lesões gengivais inflamatórias crônicas, o efeito primário dos mastócitos, presentes no interior do epitélio e no tecido conjuntivo, seria de proporcionar o aumento da destruição tecidual, promovendo e/ou acentuando a atividade enzimática15. GÜNHAN et al.81, em 1991, observaram relação entre o aumento de mastócitos e fibrose do tecido conjuntivo, em amostras gengivais humanas, sugerindo que os constituintes presentes nos grânulos citoplasmáticos destas células têm o potencial de afetar componentes do tecido conjuntivo. Ainda, para alguns autores, o número de mastócitos parece ser inversamente proporcional ao grau de inflamação tecidual, estando essas células presentes em maior quantidade durante o processo de reparo, inclusive para os casos de doença periodontal inflamatória9, 81, 236, 237. Por outro lado, FRAME \& NIXON61, em 1968, e JEFFCOAT et al. ${ }^{98}$, em 1985, observaram, em humanos e em animais respectivamente, uma correlação positiva entre presença de mastócitos e perda óssea.

A contribuição dos mediadores dos mastócitos na doença periodontal inflamatória ainda não foi estabelecida. A administração de agentes farmacológicos ativos locais ou sistêmicos, que inibem a 
degranulação de mastócitos, pode, então, ser um método útil para se investigar o papel dos mastócitos nas doenças. JEFFCOAT et al. ${ }^{98}$, em 1985, examinaram o efeito da aplicação diária de etil lodoxamida na progressão da doença periodontal inflamatória naturalmente presente em beagles e observou uma significante diminuição da taxa de perda óssea, sugerindo uma relação positiva entre presença de mastócitos e gravidade da doença periodontal.

Enquanto alguns pesquisadores7, 154 acreditam que fenômenos de hipersensibilidade imediata e/ou tardia possam ser um dos mecanismos imunológicos ativos na doença periodontal inflamatória humana, já que todos os componentes necessários para estas reações têm sido identificados em tecido gengivais, outros sugerem uma potencial interação entre mastócitos e outros componentes do sistema imune. Esta interação contribuiria para a modulação dos eventos celulares e humorais dos mecanismos de defesa do hospedeiro contra infecções bacterianas 228,231 , inclusive participando na patogênese de condições inflamatórias como a doença periodontal inflamatória. Realmente, estudos têm reportado a presença de mastócitos em íntima proximidade com células T70, 144, 185, bem como sua capacidade de fagocitar e processar antígenos bacterianos previamente à apresentação antigênica para linfócitos $\mathrm{T}^{137}$ e sua participação como fonte de citocinas indutoras de resposta imune tanto Th1 quanto Th2 ${ }^{140,}$ 170, 185, 204. Dessa forma, tem se tornado claro que os mastócitos são capazes de produzir uma extensa variedade de mediadores que resulta em uma ativação primária de mastócitos seguida por estimulação subseqüente de linfócitos T. Os mastócitos parecem ser capazes de modular as respostas proliferativas e a produção de citocinas por células T CD8 ${ }^{+46,47}$ e de apresentar antígenos a células T in vitro $60,133,137,228,239$ e in vivo 228 . Nesta condição, torna-se possível a relação íntima funcional entre ativação inicial de mastócitos e posterior estimulação de linfócitos $\mathrm{T}$, como respostas proliferativas e produção de 
citocinas por células $\mathrm{T} \mathrm{CD}^{+}$, apresentação antigênica, bem como a estimulação de resposta humoral60, 133, 185, 228, 239.

Em trabalho prévio realizado em nosso laboratório ${ }^{19}$, a presença de mastócitos foi quantificada por imuno-histoquímica, em casos de periodontite crônica localizada, gengivite associada à placa dentobacteriana e tecidos gengivais clinicamente saudáveis, revelando um aumento do número de mastócitos na presença de doença periodontal inflamatória humana, o que sugere a participação destas células na patogenia da doença, provavelmente em mecanismos de defesa e/ou fenômenos destrutivos. Porém, a real participação dos mastócitos nas doenças periodontais ainda não foi esclarecida, em especial quanto a sua participação como célula produtora de NO, MMPs e de citocinas, estimulando a reabsorção óssea e a destruição tecidual.

\section{3- Metaloproteinases e Óxido Nítrico na Doença Periodontal Inflamatória}

As MMPs constituem uma importante família de enzimas estruturalmente relacionadas, mas geneticamente distintas, que utilizam vários componentes da matriz extracelular e da membrana basal como substrato. Por isso, estas proteinases estão envolvidas em vários eventos fisiológicos durante a organogênese, o crescimento e a remodelação teciduais normais, bem como em processos patológicos, como a doença periodontal inflamatória 23 , 188, 214. Fibroblastos gengivais residentes e do ligamento periodontal produzem MMPs, provavelmente relacionadas com a remodelação tecidual normal. Em condições inflamatórias, por sua vez, células epiteliais e, principalmente, PMNs neutrófilos, também estão envolvidos na produção de MMPs77, 209. De fato, várias enzimas proteolíticas são expressas em tecidos afetados pela doença periodontal inflamatória, 
incluindo as MMPs cuja presença, de acordo com SORSA et al. ${ }^{209}$, 213, em 1988 e em 1998, pode ser detectada na gengiva, no fluido gengival e na saliva de pacientes portadores de doença periodontal inflamatória.

A atividade das MMPs é controlada por alterações no delicado balanço entre sua expressão e síntese e seus principais inibidores endógenos, os Inibidores Teciduais de Metaloproteinases (TIMPs). Enquanto a inibição da ativação ou da atividade das MMPs é de responsabilidade das TIMPs, a competência catalítica das MMPs é controlada pela ativação de pró-enzimas (proMMPs), ou seja, as MMPs são sintetizadas e secretadas em uma forma inativa, ligadas a um pequeno peptídeo de $10 \mathrm{kDa}$ que bloqueia sua função, só sendo clivadas para a ativação na presença de citocinas IL-1 e TNF- $\alpha$, endotoxinas bacterianas, e $\mathrm{NO}$ e seus reativos nitrito $\left(\mathrm{NO}_{2}^{-}\right)$e peroxinitrito (ONOO- $)^{23,150,162,224}$ no meio extracelular onde as MMPs devem agir.

Sabe-se que enzimas proteolíticas liberadas pelas células do hospedeiro estão associadas com a destruição tecidual presente na doença periodontal inflamatória, e que as MMPs possuem um papel primário neste processo, já que podem degradar a maioria dos componentes da matriz extracelular136. Vários estudos sugerem que a doença periodontal inflamatória induzida por placa dentobacteriana apresenta um comportamento cíclico, caracterizado por períodos de exacerbação, durante o qual observa-se progressiva perda óssea e destruição tecidual, seguida por períodos de remissão ${ }^{166}$, 226. Durante a progressão da doença periodontal, o epitélio juncional migra apicalmente simultaneamente com a dissolução das fibras de Sharpey mais coronalmente dispostas. Para ocorrer migração celular, os queratinócitos devem se destacar da membrana basal do epitélio, processo provavelmente mediado por degradação enzimática. O movimento ativo de células epiteliais envolve adesão às moléculas da matriz extracelular em locais de contato e subseqüente contração do citoesqueleto, o que gera forças locomotivas. A motilidade celular também requer a liberação da célula dos locais de adesão, o que é diretamente, pelo menos em parte, limitado 
pela proteólise das moléculas da matriz pelas $\mathrm{MMPs}^{90,96}$. Então, períodos de progressiva destruição tecidual da doença periodontal inflamatória envolvem significante atividade proteolítica, com síntese, secreção e ativação de enzimas proteolíticas tais como as colagenases MMP-1 e -8, e as gelatinases MMP-2 e -9136, 178, podendo ser a ativação das MMPs um dos caminhos para a degradação que contribui na patogênese da doença periodontal inflamatória $37,214$.

Vários autores já descreveram a presença de colagenases e gelatinases, tanto na forma latente quanto ativa, no tecido periodontal inflamado e no fluido gengival de regiões inflamadas ${ }^{1}$,55, 136, 209, 211, 214 . Há evidências de que a atividade da MMP-1 presente no fluido gengival, assim como em casos de gengivite e periodontite experimentais, está aumentada e correlacionada com a gravidade da doença periodontal inflamatória ${ }^{224}$. Ainda, SORSA et al.209, 212, em 1988 e em 1995, demonstraram a presença de MMP- 2, -8 e -9 na doença periodontal humana.

Em particular, as MMPs -2 e -9 têm sido identificadas como predominantes em casos de doença periodontal inflamatória em humanos e em ratos, estando relacionadas tanto com a gravidade da doença periodontal inflamatória quanto com a regulação da resposta inflamatória e da migração celular, presentes no processo de reparo tecidual1,35, 48, 55, 113, 116, 148, 205. Enquanto várias MMPs, inclusive a MMP-2, são produzidas de maneira constitutiva, a MMP-9 é secretada por um número limitado de células e de maneira não constitutiva, responsiva a fatores de crescimento e citocinas ${ }^{156}$, o que a torna um mediador inflamatório potencialmente importante na doença periodontal inflamatória.

Por meio de zimografia e análise por Western blot, KOROSTOFF et al.113, em 2000, detectaram a presença de MMP-2 em forma latente e ativa, e de MMP-9 latente em todas as amostras de tecido gengival humano tanto saudável quanto inflamado, porém em níveis mais elevados nos tecidos afetados pela doença periodontal inflamatória. No entanto, os resultados de 
SORSA et al.211, em 1994, revelaram baixa imunorreatividade a anticorpos anti-MMP-2 em tecidos gengivais inflamados.

Em ratos submetidos à indução da doença periodontal inflamatória por meio de ligadura, ACHONG et al. ${ }^{1}$, em 2003, encontraram expressão aumentada de MMP-2 nas formas ativa e inativa, sugerindo sua participação nas diferentes fases evolutivas da doença, desde a desorganização da membrana basal e parte da reabsorção óssea e radicular, até na migração celular e reestruturação da matriz extracelular. Ainda, CESAR NETO et al.35, em 2004, ao relacionarem a influência da inalação intermitente de fumaça de cigarro na progressão da doença periodontal inflamatória induzida em ratos, demonstraram aumentos locais dos níveis e da atividade de MMP-2 frente à fumaça ao redor dos dentes com ligadura, sugerindo uma participação de ambas no aumento da perda óssea observada em fumantes.

Quanto à fonte das MMPs, estudos moleculares revelaram o isolamento de RNAm para MMP de vários tipos celulares presentes no periodonto, incluindo fibroblastos gengivais e do ligamento periodontal, PMNs neutrófilos, macrófagos, queratinócitos, células endoteliais, osteoblastos, osteoclastos e mastócitos ${ }^{14,107,145,187,236,237}$. No entanto, os PMNs neutrófilos têm sido reconhecidos como a fonte mais importante de MMPs ${ }^{1}$, 136, 205, 209, especialmente porque armazenam grandes quantidades de MMP-9 em seus grânulos intracelulares, sendo a taxa de degranulação o possível fator principal que determina as fases de quiescência e aguda da doença periodontal inflamatória 207.

Além disso, há evidências de que o contato direto entre mastócitos e células T também estimule os mastócitos a produzir e liberar mediadores, citocinas e MMP-9, que possuem propriedades imunorreguladoras e/ ou imunomoduladoras ${ }^{14}$. A ativação da via metaloproteinase envolve destruição de todo o tecido conjuntivo não mineralizado e inclusive reabsorção óssea; sendo assim, o aumento da 
expressão de MMPs está associado com a progressão da doença periodontal166, 226. Contudo, as vias de ativação das MMPs nesta doença ainda não foram completamente esclarecidas.

A presença de NO também tem sido considerada um sinal molecular importante em uma grande variedade de tecidos, podendo representar uma função significante como um mediador citotóxico da resposta imune inespecífica, ou ainda estar relacionada tanto com efeitos prejudiciais quanto benéficos na fisiopatologia dos tecidos 103, 114, 149 .

O NO é sintetizado por uma família complexa de enzimas chamadas NO sintases (NOS), que requerem muitos fatores e co-fatores para sua atividade, a partir do aminoácido L-arginina. Existem três tipos de enzimas NOS: nNOS, presente em tecidos neurais, eNOS, encontrada em células endoteliais, ambas expressas constitutivamente, e iNOS, uma forma induzível de NOS encontrada em várias células, incluindo macrófagos e células natural killer do sistema imune, cuja expressão depende do equilíbrio de citocinas pró-inflamatórias, como a estimulação por IL-1 $\beta$, TNF- $\alpha$ e IFN- $\gamma$, e a inibição por TGF- $\beta$ (fator de crescimento transformador-beta), IL-4 e IL1030, 43. As isoformas constitutivas de NOS (eNOS e nNOS) produzem rapidamente -de segundos a minutos- pequenas quantidades de NO, enquanto a iNOS produz grandes quantidades de $\mathrm{NO}$ e por longos períodos de tempo -por horas a dias-, o que se torna citotóxico ${ }^{119}$. Macrófagos, PMNs neutrófilos e células endoteliais ativadas podem, ainda, secretar produtos intermediários reativos do oxigênio, principalmente o peroxinitrito, que exercem ação tóxica cooperativa com o $\mathrm{NO}^{114}$. Este potencial citotóxico de altos níveis de NO parece ser rigorosamente controlado pela necessidade de um iniciador e um gatilho, IFN- $\gamma$ e IL-1 ou LPS, para induzir resposta, isto é a expressão gênica de iNOS. Por exemplo, o IFN- $\gamma$ pode superinduzir a produção de NO por macrófagos ativados por outros estímulos, como LPS132.

Embora existam poucos estudos sobre o papel do $\mathrm{NO}$ em doenças bucais, alguns autores relatam sua presença na doença periodontal 
inflamatória 18 , 30, 43, 130, 131, 141, 169. Conhecidamente, o NO é um dos compostos antibacterianos mais poderosos, agindo tanto na inibição do crescimento bacteriano quanto aumentando a citotoxicidade mediada por macrófagos. Por ser um gás, penetra facilmente através da membrana celular e pode induzir danos microbianos por vários mecanismos, como pela inibição do DNA de várias sintases, pela combinação com enzimas mitocondriais essenciais para a respiração celular, e com superóxido para formar ácido peroxinitroso e radical hidroxila altamente reativo $93,139,149,150$.

Provavelmente, os componentes da placa dentobacteriana, especialmente os LPS, juntamente com as citocinas inflamatórias secretadas durante a doença periodontal inflamatória sejam os responsáveis pela ativação de iNOS. Então, a produção de iNOS, por células inflamatórias e até mesmo fibroblastos gengivais, pode ser uma tentativa de se eliminar os microrganismos da placa dentobacteriana; no entanto, as concentrações de NO produzidas resultam em grande destruição tecidual $30,43,130,169$.

Estudos em indivíduos fumantes e não fumantes não portadores de doença periodontal inflamatória revelaram uma associação positiva entre deposição de placa dentobacteriana supragengival recente e aumento significante nos níveis bucais de $\mathrm{NO}$ e de nitrito salivar dos pacientes não fumantes ${ }^{32}$, sugerindo uma ativação da iNOS nessas condições. Esta hipótese é suportada pelas observações de MATEJKA et al.141, em 1998, que encontraram um aumento dos precursores L-arginina e L-citrulina em casos de doença periodontal inflamatória de indivíduos não fumantes. Ainda, relacionando-se a fumaça com a doença periodontal inflamatória, no estudo de CAROSSA et al. ${ }^{32}$, em 2001, os indivíduos fumantes apresentaram níveis significativamente menores de NO, podendo-se sugerir que a freqüência e a gravidade da doença periodontal inflamatória encontrada em fumantes pode, pelo menos em parte, ser conseqüência de uma diminuição dos níveis de $\mathrm{NO}^{27}, 32,105$, que pode ser atribuída à redução da sensibilidade celular à presença de iNOS pelas altas concentrações de NO presentes na 
fumaça do cigarro. Interessantemente, no mesmo estudo, os fumantes apresentaram uma maior quantidade de bactérias em sua placa dentobacteriana, um achado que suporta o papel do NO como um modulador da proliferação bacteriana e sugere que a produção prejudicada de NO pode contribuir para uma doença periodontal inflamatória mais grave em fumantes.

Estudos prévios em nosso laboratório ${ }^{18}$ indicam que, em tecidos periodontais humanos, o NO aumenta na presença de doença periodontal inflamatória. Neste contexto, o NO pode estar associado com a regulação da destruição tecidual e reabsorção óssea ou ainda com fenômenos imunopatológicos. Estes achados indicaram também uma via adicional de ativação de células inflamatórias na doença periodontal, em especial dos PMNs neutrófilos, que expressaram iNOS significativamente, provavelmente representando uma importante origem de NO nesta doença.

Em modelos animais, a indução experimental da doença periodontal inflamatória em ratos, por meio de ligadura, revelou expressão e atividade aumentadas de iNOS por células inflamatórias e da camada basal do epitélio gengival. Ainda, ratos submetidos às mesmas condições anteriores, porém tratados com inibidores seletivos de iNOS, resultou em redução significativa da infiltração por células inflamatórias e reabsorção óssea alveolar, além de danos teciduais mais moderados em relação às amostras controle, revelando o efeito benéfico da utilização de inibidores seletivos de iNOS na gravidade da doença periodontal inflamatória ${ }^{49,130 .}$ 


\section{4-Aspectos fisiológicos dos tecidos periodontais}

O termo periodonto refere-se aos tecidos de suporte -cemento radicular, ligamento periodontal, osso alveolar- e de revestimento -gengiva-, sendo que estes tecidos desenvolvem-se e funcionam como uma unidade ${ }^{38}$.

\section{Periodonto de Revestimento - Gengiva e Junção dentogengival}

A gengiva é a parte da mucosa mastigatória que cobre o processo alveolar e circunda a porção cervical dos dentes, assumindo sua forma e textura definitivas em associação com a erupção dentária. Em direção à coroa, a gengiva termina na margem gengival livre, que possui contorno parabólico, enquanto que, em sentido apical, é contínua com a mucosa alveolar, da qual é separada pela junção mucogengival123.

A área que conecta dente e gengiva é chamada de junção dentogengival, que possui características arquiteturais e morfológicas especificamente relacionadas com a união da gengiva ao dente, apresentando componentes teciduais epitelial e conjuntivo. Estes componentes podem ser subdivididos em regiões funcionais: o tecido epitelial em gengival, sulcular e juncional; e o tecido conjuntivo em superficial e profundo $0^{38,63}$.

\section{Componente Epitelial da Junção Dentogengival}

O epitélio gengival, que se estende da margem gengival livre à junção mucogengival, é do tipo pavimentoso estratificado ortoqueratinizado e encontra-se em continuidade com o epitélio estratificado sulcular, voltado para a superfície dentária embora não aderido ao dente, e delimitando o espaço referente ao sulco gengival. Em humanos, o epitélio sulcular não é queratinizado, enquanto que, em ratos, este epitélio é paraqueratinizado ${ }^{108}$, o que supostamente possibilita uma maior proteção dos tecidos conjuntivos de 
suporte contra a resposta inflamatória a agentes agressores da placa dentobacteriana em ratos.

A base do epitélio sulcular continua-se com o epitélio juncional, sobrepondo-se lateralmente à sua superfície e inserindo-se nele por meio de junções intercelulares bem definidas do tipo desmossomos. Embora não apresente estratificação verdadeira, as células do epitélio juncional tendem a ser alongadas e a repousar seu longo eixo axial paralelamente à superfície dentária, exibindo firme adesão ao dente e ao tecido conjuntivo adjacente, por meio da lâmina basal e de hemidesmossomos que unem a gengiva ao dente. O epitélio juncional torna-se mais fino à medida que progride apicalmente, em direção à junção cemento-esmalte e apresenta espaços intercelulares grandes, porém no interior destes espaços são encontradas células MN e PMNs, oriundas do tecido conjuntivo subjacente, que migram em direção ao fundo do sulco gengival, mesmo na condição de saúde periodontal. Esta característica do epitélio juncional acaba permitindo, também, a entrada de antígenos ${ }^{38,63}$. No entanto, o epitélio juncional exibe várias características estruturais e funcionais únicas que contribuem na prevenção da colonização da superfície dentária subgengival por bactérias periodontopatogênicas. Entre elas está sua firme adesão ao dente, formando uma barreira epitelial contra a placa dentobacteriana, o acesso à margem gengival do fluido gengival, de células inflamatórias e componentes do sistema imune do hospedeiro, bem como a elevada taxa de renovação das células do epitélio juncional, que contribui para o equilíbrio hospedeiroparasita e para o rápido reparo do tecido destruído ${ }^{171}$. Ainda, há evidências da capacidade endocítica das células do epitélio juncional, semelhante à dos macrófagos e neutrófilos ${ }^{38}$. Estudos mais recentes relatam a distribuição de filamentos de queratina citoplasmáticos nas células do epitélio juncional, a presença de diferentes antígenos e receptores de superfície, de moléculas de adesão intercelular, e de células não epiteliais ao longo do epitélio juncional ${ }^{197}$. Essas propriedades suportam a possibilidade da formação de 
uma junção eficiente entre dois tecidos diferentes e a capacidade flexível de resposta ao ambiente externo.

\section{Componente Conjuntivo da Junção Dentogengival}

Existem muitas fibras colágenas no periodonto de proteção associadas à manutenção da integridade dos dentes, formando o ligamento gengival. Essas fibras podem se distribuir irregularmente, porém a maioria tende a se dispor em grupos de feixes supra-alveolares com orientação bem definida. De acordo com sua inserção e trajetória, os feixes de fibras gengivais podem ser divididos nos seguintes grupos:

- circular: as fibras formam uma faixa em torno da região cervical do dente;

- dentogengival: as fibras estão embutidas no cemento da porção supra-alveolar da raiz, de onde se projetam, em forma de leque, em direção à lâmina própria, tanto da gengiva marginal livre quanto da inserida;

- dentoperiosteal: as fibras inserem-se na mesma porção de cemento que as fibras dentogengivais, porém fazem trajetória no sentido apical sobre periósteo, terminando no tecido da gengiva inserida;

- alveologengival: as fibras irradiam da crista alveolar e estendem-se coronalmente para a lâmina própria das gengivas livre e inserida

- transeptal: as fibras estendem-se entre o cemento supraalveolar de dentes vizinhos, seguindo um trajeto retilíneo sobre o septo interdentário, e inserindo-se no dente adjacente.

As fibras gengivais supra-alveolares asseguram o dente contra o movimento de rotação e mantêm a conexão dentária durante a tendência à mesialização. As forças de tração na matriz extracelular produzidas por fibroblastos talvez sejam as forças motoras responsáveis pela geração de 
tensão no colágeno, mantendo os dente firmemente conectados uns aos outros e ao osso alveolar ${ }^{38}$.

É importante ressaltar que o tecido conjuntivo subjacente ao epitélio da junção dentogengival apresenta, mesmo em gengivas clinicamente saudáveis, células inflamatórias especialmente PMNs. Estas células migram continuamente para os epitélios juncional e sulcular, atravessando as células epiteliais, até chegarem ao sulco e fluido gengivais ${ }^{63}$, 123.

\section{Periodonto de Sustentação - Ligamento Periodontal}

O ligamento periodontal é o tecido conjuntivo especializado, situado entre o cemento que recobre a raiz dentária e o osso que forma o processo alveolar, bem adaptado para suportar o dente em seu alvéolo e permitir que ele resista às forças da mastigação. O ligamento periodontal é, portanto, composto tanto por células, como os osteoblastos, osteoclastos, fibroblastos, restos epiteliais de Malassez, macrófagos, células mesenquimais indiferenciadas e cementoblastos, quanto por feixes de fibras colágenas bem definidos $^{63}$. O desenvolvimento das fibras do ligamento periodontal está estreitamente relacionado com a formação radicular e, em geral, a maioria delas possui um curso em direção coronal, do cemento ao osso, formando um grupo específico de fibras denominado oblíquo. Com a continuação do desenvolvimento radicular, um feixe principal de fibras é estabelecido como estruturas contínuas inseridas no osso e cemento como fibras de Sharpey ${ }^{38}$.

Por ser uma estrutura cuja integridade funcional é fundamental para a manutenção da saúde periodontal, detalharemos, a seguir, cada um dos componentes principais do ligamento periodontal. 


\section{- Células}

Os fibroblastos, células mais abundantes do ligamento periodontal, são responsáveis pelo metabolismo dos componentes da matriz extracelular. São capazes de sintetizar e degradar o colágeno simultaneamente, sendo que qualquer interferência em sua função por uma doença, como a doença periodontal inflamatória, produz uma perda de tecido de suporte do dente. Microscopicamente, os fibroblastos exibem citoplasma alongado bem polarizado e apresentam-se alinhados ao longo da direção geral dos feixes de fibras, possuindo extensos processos que envolvem estes feixes. Existe um grau de heterogeneidade na população de fibroblastos do ligamento periodontal; possuem o citoesqueleto bem desenvolvido, indicando um papel funcional correspondente à capacidade de alteração de forma e migração ${ }^{63}$.

Os restos epiteliais de Malassez são remanescentes da bainha epitelial de Hertwig encontrados no ligamento periodontal, reconhecidos microscopicamente como agrupamentos ou ilhotas com cerca de 4 a 20 células arredondadas a ovais, ou como cordões de células entrelaçadas, junto à superfície de cemento, ao longo do comprimento da raiz dentária, cuja função permanece desconhecida ${ }^{63}$. Os restos epiteliais de Malassez têm sido, ainda, relacionados com a formação de cistos odontogênicos ${ }^{128}$ e com a resposta inflamatória à infecção bacteriana ${ }^{127}$ e movimentação dentária ortodôntica72, 225. A inflamação gengival também pode estimular a proliferação local dos restos epiteliais de Malassez no terço superior da raiz, especialmente em animais mais idosos. Especula-se, então, que exista uma relação entre os restos epiteliais de Malassez, os vasos sangüíneos do ligamento periodontal e a reabsorção radicular ${ }^{101}$.

As células mesenquimais indiferenciadas localizam-se em regiões perivasculares e possuem o aspecto morfológico de células estrelares. Durante o reparo tecidual, novos fibroblastos são derivados destas células progenitoras perivasculares presentes no ligamento periodontal normal 
adjacente. Os espaços medulares do osso alveolar também são locais de proliferação celular, contribuindo especialmente na formação de novo cemento e na deposição de novo colágeno no ligamento periodontal ${ }^{38}$.

Os osteoblastos apresentam-se morfologicamente como células ora arredondadas ora achatadas, alinhadas e recobrindo a superfície óssea do ligamento periodontal, podendo estar funcionais ou em repouso. Em áreas de reabsorção ativa, no entanto, o que se observa em íntima proximidade, e até mesmo acoplados à superfície óssea em lacunas de Howship, são os osteoclastos, geralmente organizados como células gigantes multinucleadas.

Os cementoblastos encontram-se alinhados na superfície de cemento, porém os fibroblastos do ligamento periodontal possuem uma relação mais próxima com a superfície cementária63.

\section{- Fibras colágenas}

As fibras colágenas do ligamento periodontal encontram-se, em sua maioria, arranjadas na forma de feixes bem definidos. Microscopicamente, observam-se grupos distintos de fibras colágenas, incluindo-se os grupos:

- da crista alveolar: fibras unidas ao cemento, situadas logo abaixo da junção cemento-esmalte, dirigindo-se para baixo e externamente, e inserindo-se na crista óssea alveolar;

- horizontal: fibras situadas apicalmente ao grupo da crista alveolar, dirigem-se do cemento para o osso, logo abaixo da crista alveolar;

- oblíquo: constitui a maior parte do ligamento periodontal (cerca de 2/3), as fibras situam-se apicalmente ao dente e coronalmente ao osso, opondo-se às forças intrusivas;

- apical: as fibras irradiam-se do cemento para o osso, em torno do ápice da raiz, formando a base do alvéolo;

- inter-radicular: as fibras ancoram-se entre as raízes dos dentes multirradiculares. 


\section{5- Doença Periodontal Inflamatória Experimental}

Ao contrário de outras doenças infecciosas humanas, que não têm correspondentes em outras espécies, a doença periodontal inflamatória é comum no reino animal. Diferentes modelos animais podem ser utilizados para se avaliar a patogênese ou até mesmo as modalidades terapêuticas possíveis com relação à doença periodontal inflamatória. É importante ressaltar, porém, que a anatomia da junção dentogengival da região de molares de rato é muito semelhante àquela descrita no homem, tornando o estudo experimental da doença periodontal inflamatória nesses animais uma ferramenta bastante válida124. Em ratos, esta doença pode ser induzida por meio de manipulação dietética 67,108 , 184, 190, da inoculação experimental de microrganismos periodontopatogênicos ou de seus produtos ${ }^{58,} 108$ e, ainda, por meio da colocação de ligaduras ao redor da região cervical do molar do animal 82, 108, 130, geralmente o primeiro molar superior ou inferior, que funcionam como sítio para colonização bacteriana.

A doença periodontal inflamatória induzida pela modificação dos hábitos alimentares do animal consiste na administração de uma dieta rica em sacarose. Ao se comparar ratos alimentados com dieta convencional e com dieta apresentando altos níveis de sacarose, em ambos se observaram deposição gradativa de placa dentobacteriana e infiltração por PMNs logo abaixo do epitélio gengival; porém este infiltrado inflamatório se estendeu apicalmente em direção à crista óssea alveolar, onde se observou intensa atividade osteoclástica, somente mediante dieta rica em sacarose. Este desenvolvimento "natural" da doença periodontal inflamatória crônica pode ocorrer, então, devido a um aumento da síntese bacteriana de polissacarídeos extracelulares, que por sua vez facilitam a adesão e a colonização bacterianas na superfície dentária e/ou devido a um aumento da fagocitose bacteriana por PMNs, com conseqüente liberação de enzimas lisossomais ${ }^{67,188}$. Ainda, alguns autores relatam que a impacção de pêlos e debris no periodonto de 
ratos é comum em animais germ free, infectados e convencionais, sugerindo que o trauma causado por estes fatores pode ter efeito sinérgico no acesso de bactérias e seus produtos nas porções mais profundas dos tecidos periodontais $^{25}$. No entanto, nesta forma de estudo da doença periodontal inflamatória, deve-se considerar as variações existentes entre espécies e linhagens de animais, visto que há estudos que relatam maior suscetibilidade de certas linhagens à perda natural de tecido periodontal ${ }^{13}$, bem como variações ambientais e de idade dos animais, fatores importantes com relação à composição da microbiota bucal ${ }^{108}$.

Devido à confirmação da patogenicidade, em ratos, de grande quantidade de microrganismos da microbiota bucal humana, algumas das bactérias periodontopatogênicas que podem ser utilizadas na indução experimental da doença periodontal inflamatória são Actinobacillus actinomycetemcomitans, Phorphyromonas gingivalis, Prevotella intermedia e Fusobacterium nucleatum 51, 52, 108, 110. Pode-se, ainda, inocular o tecido gengival com LPS, visando estimular a liberação de mediadores inflamatórios responsáveis pelo recrutamento de leucócitos PMNs, pela vasodilatação e edema, bem como a ativação osteoclástica e subseqüente destruição óssea nos tecidos periodontais inflamados 50,166 .

A irritação mecânica local e a promoção da formação de placa dentobacteriana pela colocação de ligadura com fio de seda ou algodão ao redor da região cervical de primeiros molares, inferiores ou superiores, também tem sido amplamente utilizada na indução da doença periodontal inflamatória experimental1，82, 130. Apesar da localização subgengival da ligadura e de sua associação com agregados e biofilmes microbianos, um revestimento epitelial inicialmente bem definido a separa do tecido conjuntivo subjacente. A partir de então, em resposta à agressão mecânica e ao acúmulo gradualmente mais exuberante de placa dentobacteriana ao redor da ligadura, ocorrem períodos de inflamação aguda, com migração de células inflamatórias, especialmente PMNs, seguidos por perda de tecido 
conjuntivo e períodos de inflamação crônica, caracterizando a instalação da doença periodontal inflamatória.

Os achados clínicos e microscópicos da doença periodontal inflamatória experimentalmente induzida em ratos são semelhantes àqueles no homem. Clinicamente, nota-se sangramento gengival sob sondagem suave e, microscopicamente, o epitélio juncional sofre alterações graduais como formação de cristas epiteliais, ulceração e migração apical. Observa-se ainda, no tecido conjuntivo subjacente, infiltrado inflamatório contendo linfócitos T e B, macrófagos e PMNs neutrófilos, estes podendo ser observados também no sulco gengival, bem como destruição de fibras colágenas e atividade osteoclástica aumentada $67,68,97,108,219$.

ROVIN et al. ${ }^{186}$, em 1966, ao estudarem a influência de bactérias e irritação mecânica local na iniciação da doença periodontal inflamatória em ratos convencionais e germ-free, relataram a importância da associação entre a colocação da ligadura e a presença de microbiota bucal. De acordo com seus resultados, tanto a colonização bacteriana quanto a colocação da ligadura isoladas não foram capazes de produzir inflamação, sendo necessária a presença de ambos os fatores para se iniciar a doença periodontal inflamatória experimental. Seguindo este raciocínio, porém visando uma indução mais rápida e evidente da doença periodontal inflamatória, muitos pesquisadores optam, ainda, pela colocação de ligaduras embebidas em bactérias periodontopatogênicas ${ }^{106,191}$.

Uma vez definido o método de indução da doença periodontal experimental, uma série de estudos pode ser realizada com relação à sua patogênese, evolução e terapêutica. Dentre os trabalhos nesta linha de pesquisa, muitos se referem a aspectos microbiológicos e imunopatológicos, com ênfase especialmente nos tipos celulares presentes, citocinas, quimiocinas e outros mediadores inflamatórios envolvidos na iniciação e evolução da doença periodontal inflamatória. Entretanto, apesar da grande contribuição dos trabalhos experimentais e da semelhança anatômica e 
fisiopatológica entre os mecanismos inflamatórios presentes na doença periodontal inflamatória experimental e humana, é importante considerar as limitações de cada metodologia, especialmente quanto à extrapolação dos resultados para a doença periodontal inflamatória humana. 


\section{2- PROPOSIÇÃO}

O presente trabalho teve como objetivo caracterizar o modelo experimental da doença periodontal inflamatória induzida por ligadura em ratos, com ênfase na avaliação clínica e microscópica, bem como no estudo quantitativo dos mastócitos e da presença de RNAm codificador das enzimas iNOS e MMP-2 e -9, em diferentes períodos. 


\section{3- MATERIAL E MÉTODOS}

\section{1- Animais e Protocolo de Indução da Doença Periodontal Inflamatória}

Os animais utilizados no presente estudo consistiram de ratos Wistar, albinos, machos, com peso médio entre 70 a 100g, mantidos no Biotério da Faculdade de Odontologia de Bauru (FOB-USP) e alimentados com ração normal e água ad libitum. Os animais foram submetidos à colocação de ligadura nos primeiros molares inferiores do lado direito (grupo experimental), sendo o lado oposto utilizado como controle (grupo controle). Para o estudo da doença periodontal inflamatória experimental e amostras controle, os experimentos foram realizados em três etapas, sendo a primeira destinada à análise microscópica morfológica de amostras contendo tecido mineralizado dentário e ósseo adjacente, a segunda às análises microscópica e histoquímica (azul de toluidina) dos tecidos moles adjacentes (amostras gengivais), e a terceira à análise por Reação em Cadeia da Polimerase precedida por Transcrição Reversa (RT-PCR) dos tecidos moles adjacentes. Para cada período de cada experimento, utilizou-se um $n$ de 3 animais. Para a avaliação microscópica morfológica das amostras contendo tecido mineralizado, utilizaram-se animais com idade aproximada de 120 dias; enquanto que, para as análises microscópica, histoquímica e molecular dos tecidos moles adjacentes, utilizaram-se animais com idade de aproximadamente 60 dias, correspondente a um adulto jovem.

A manipulação animal seguiu o protocolo aprovado pelo COBEA (Colégio Brasileira de Experimentação animal) e pelo Comitê de Ética no Ensino e Pesquisa em Animais da FOB-USP, ao qual o presente trabalho foi submetido e sua realização deferida (Anexos 1 e 2). Os animais foram anestesiados utilizando-se um relaxante muscular (Anasedan ${ }^{\circledR} ; 0,07$ ou 0,10 $\mathrm{mL}$ de uma solução estoque de $23 \mathrm{mg} / \mathrm{mL}$ ) e um anestésico geral à base de Ketamina (Dopalen ${ }^{\circledR}$; 0,07 ou 0,10 mL de uma solução estoque de 
$116 \mathrm{mg} / \mathrm{mL}$ ), por meio de injeção intramuscular. A ligadura constituiu de um fio de seda preto 3-0 estéril colocado na região cervical do primeiro molar inferior direito, tomando-se o cuidado de penetrar o fio no sulco gengival, portanto em íntima proximidade aos tecidos gengivais, ficando o nó na região mesial, de acordo com GYÖRFI et al. ${ }^{82}$, em 1994, e LOHINAI et al. ${ }^{130}$, em 1998 (Figura 1).

Para a avaliação microscópica referente à primeira etapa experimental, o sacrifício dos animais foi feito nos períodos de 1, 3, 7, 14, 28, 42 e 56 dias após a colocação da ligadura, por meio de dose excessiva de anestésico. A mandíbula foi removida, preservando-se o tecido gengival, sendo, então, separada em duas hemimandíbulas. O material foi fixado em solução de formol a $10 \%$ tamponado com fosfato $(\mathrm{pH}=7,0)$, cortado em blocos de aproximadamente $8 \times 10 \times 6 \mathrm{~mm}$ (contendo o primeiro molar inferior) e desmineralizado em solução de EDTA 7\%, por aproximadamente 45 dias. As amostras foram seccionadas no sentido mesio-distal, submetidas ao processamento histotécnico de rotina, incluídas em parafina e cortadas em micrótomo (Leica) a $5 \mu \mathrm{m}$, sendo aderidas em lâminas de vidro comuns para microscopia (Corning) e coradas em Hematoxilina e Eosina (HE).

Para a análise microscópica e histoquímica dos tecidos moles adjacentes, correspondentes à segunda etapa do experimento, o sacrifício dos animais foi feito nos períodos de 1, 3, 7, 14 e 30 dias após a colocação da ligadura, definidos como períodos mais significativos, após análise das lâminas coradas em HE contendo os tecidos mineralizados. Imediatamente após o sacrifício dos animais, foi removida cuidadosamente, com lâmina de Bisturi 15C (Med Blade) e descolador Molt (Quinelato), uma faixa de tecido gengival, compatível com mucosa queratinizada, que circundava o primeiro e cerca de metade do segundo molar inferior, de ambos os lados (Figura 2). Em seguida, as faixas obtidas foram estendidas sobre papel cartão, a fim de se evitar dobras no tecido, separando-se os tecidos correspondentes às regiões vestibular e lingual, e embebidos em solução de formol a $10 \%$ 
tamponado por 48 horas para fixação dos espécimes. Após este período, as faixas de tecido gengival (vestibular e lingual) foram submetidas a dois cortes no sentido ocluso-apical, resultando em três fragmentos teciduais de dimensões semelhantes. Os dois fragmentos posteriores foram desprezados e aquele localizado na região mais mesial foi incluído em parafina, no sentido ocluso-apical, de maneira que fosse possível a visualização microscópica dos tecidos gengivais e seus planos mais profundos, nas proximidades do nó mesial, por vestibular e lingual (Figura 3). Posteriormente, as amostras parafinadas foram cortadas em micrótomo (Leica) a $5 \mu \mathrm{m}$, sendo aderidas em lâminas de vidro comum para microscopia (Corning). Em seguida, as amostras em lâminas de vidro comum foram coradas ora em HE ora com azul de toluidina (AT) para análise histoquímica.

Para a análise por RT-PCR, o sacrifício dos animais também foi feito nos períodos de 1, 3, 7, 14 e 30 dias após a colocação da ligadura. Imediatamente após o sacrifício e remoção da faixa de tecido gengival, como explicado anteriormente, os tecidos gengivais circundando os primeiros molares inferiores direito e esquerdo foram imersos em TRIzol (Gibco BRL Life Technologies, Frederick, MD, Estados Unidos), acondicionados em tubos para microcentrífuga e imediatamente congelados a $-80^{\circ} \mathrm{C}$ para posterior extração do RNA, seguindo-se o protocolo recomendado pelo fabricante (Gibco BRL, USA), e tratamento das amostras com DNAse (Qiagen, Hilden, Alemanha). 

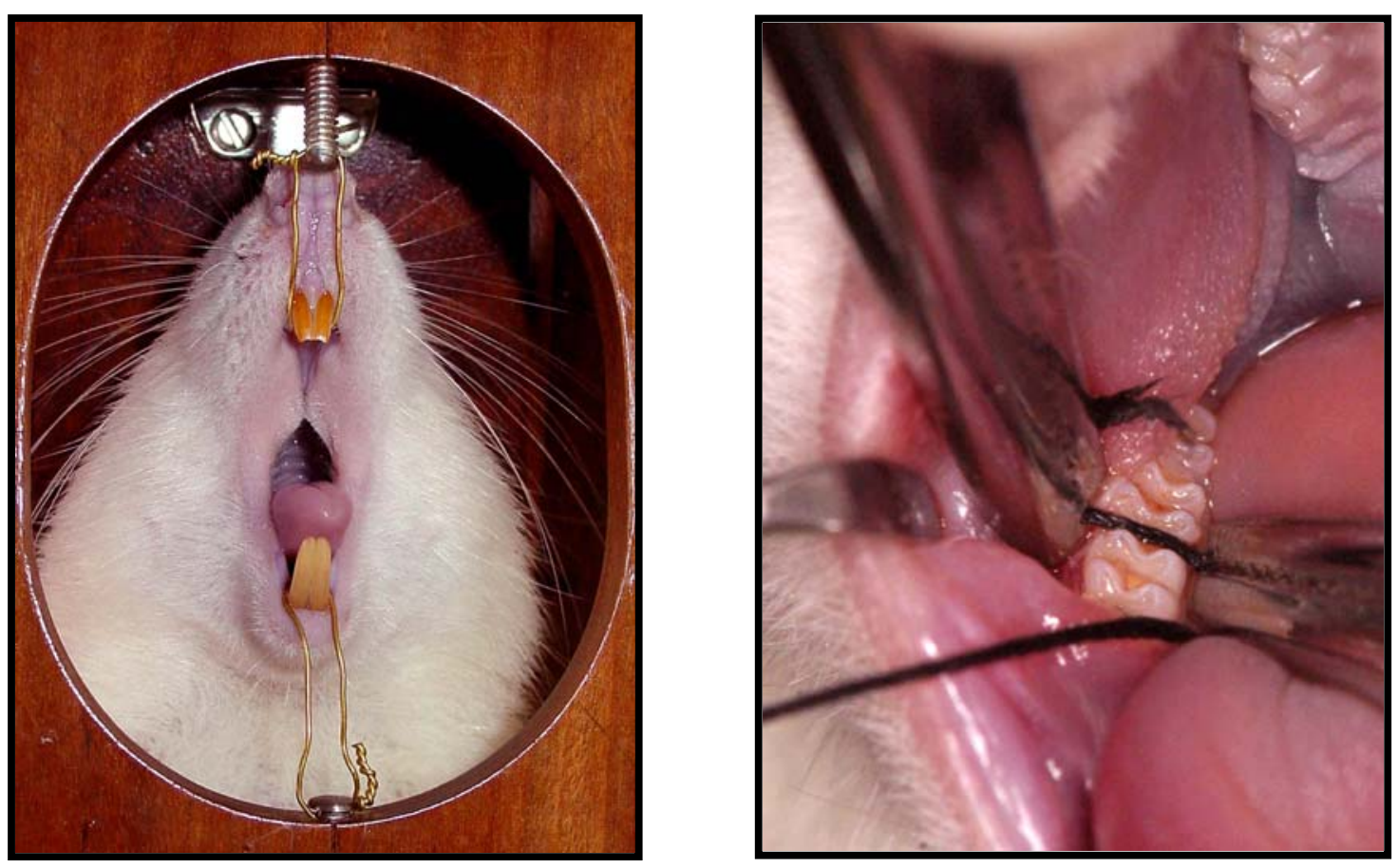

Figura 1: Seqüência de colocação da ligadura, utilizando-se fio de sutura de seda 3-0, na região cervical do primeiro molar inferior direito. O nó é mantido na região mesial e o fio delicadamente inserido subgengivalmente em todas as faces do dente.
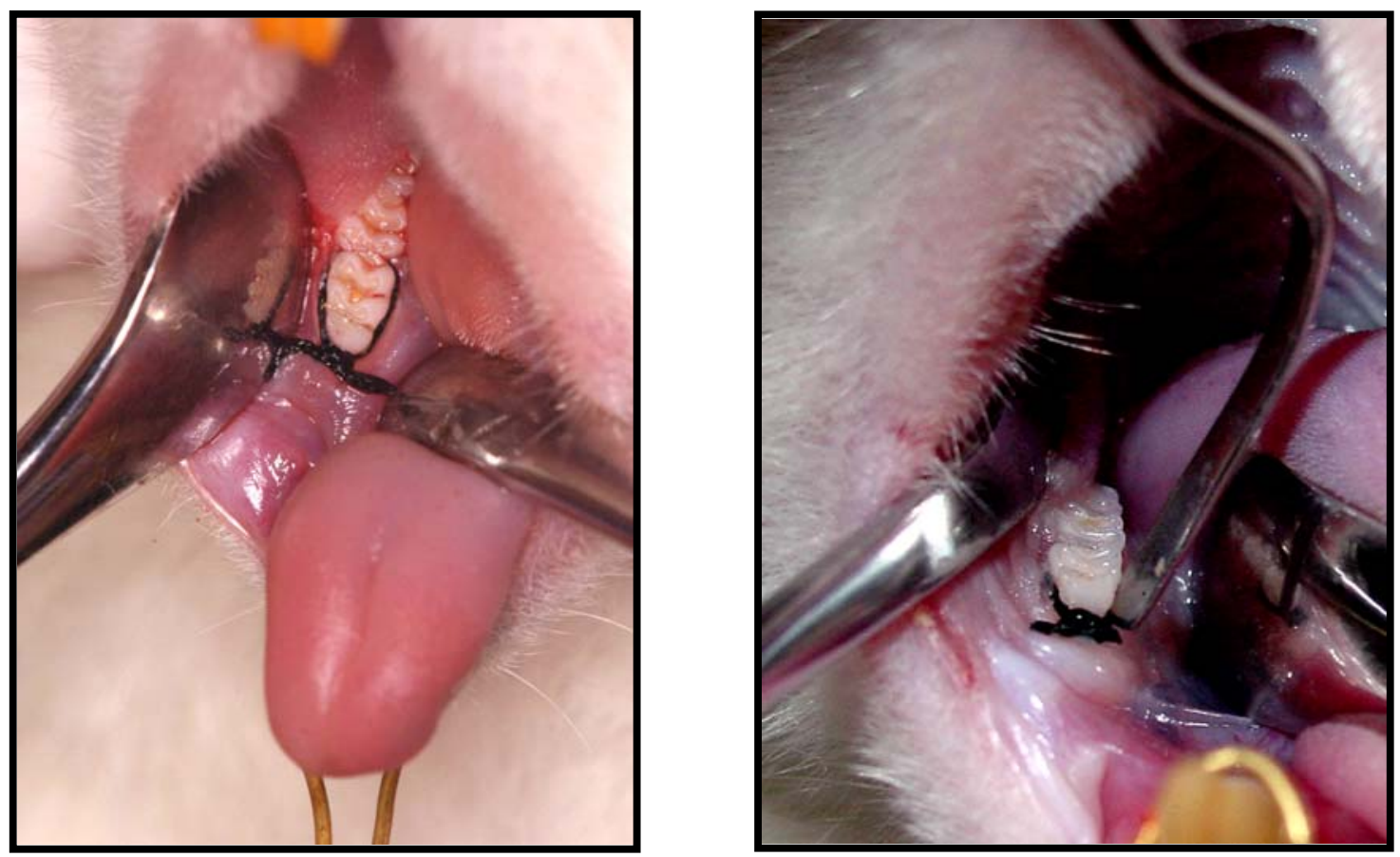


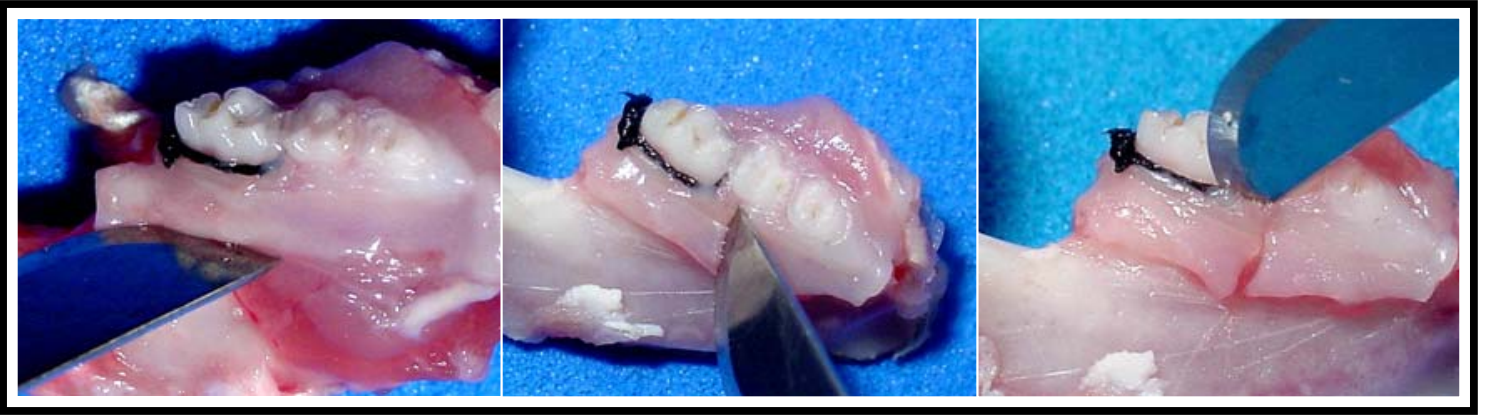

Figura 2: Delimitação da área a ser analisada microscopicamente, correspondente a uma faixa de tecido gengival, compatível com mucosa queratinizada, que circundava o primeiro e cerca de metade do segundo molar inferior.

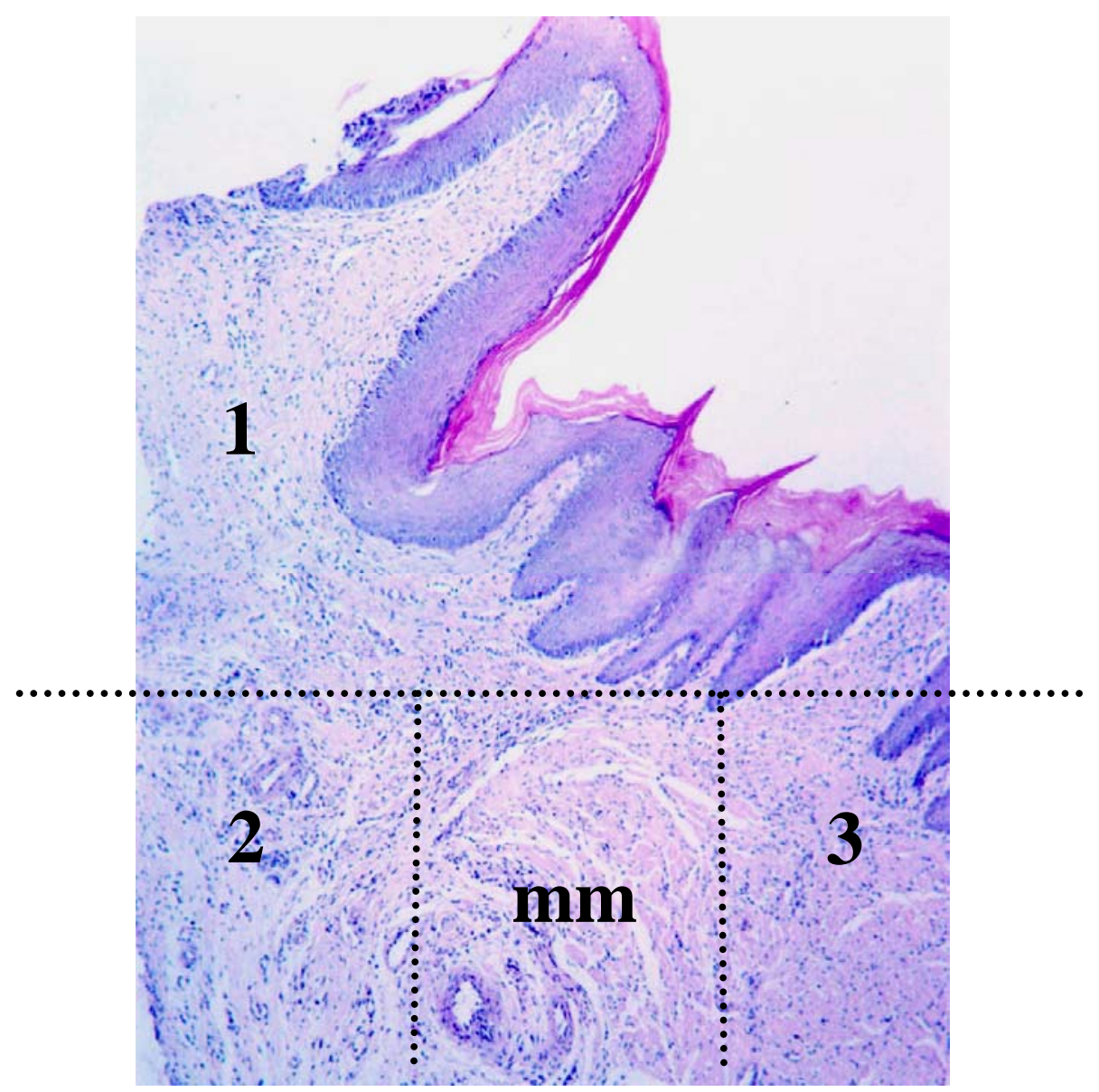

Figura 3: Fotomicrografia correspondente à porção mesial da faixa de tecido gengival removida, que foi submetida a um corte no sentido ocluso-apical. A análise microscópica se concentrou nas regiões delimitadas como 1, 2 e 3. (AT; aumento original de 25x; mm: músculatura esquelética). 


\section{2- Análise macroscópica clínica}

Baseado em seis parâmetros previamente estabelecidos, imediatamente antes do sacrifício dos animais e da remoção da mandíbula e da faixa de tecido gengival, realizou-se a análise clínica do primeiro molar inferior direito e seus tecidos periodontais adjacentes, aos dias 1, 3, 7, 14 e 30 dias após a indução experimental. Como durante o procedimento para a colocação do fio a manutenção da integridade total do tecido periodontal não foi possível, alguns dos parâmetros estabelecidos foram: (1) presença de pequenas áreas ulceradas compatíveis com trauma transoperatório e (2) pseudomembrana recobrindo estas áreas. Os outros parâmetros de análise clínica foram: (3) sangramento ao toque, verificado com instrumento sem ponta ativa (espátula de inserção no 1; Duflex), (4) aumento volumétrico gengival, compatível com edema tecidual, (5) mobilidade dentária e (6) presença de placa dentobacteriana aderida aos dentes com ligadura.

Para cada parâmetro analisado, foram estabelecidos escores subjetivos correspondentes a: discreto $(+)$, moderado $(++)$, intenso $(+++)$ e muito intenso $(++++)$, e quando necessário, de acordo com a localização (V: vestibular; L: lingual). Os resultados foram expressos de forma descritiva e reunidos em uma Tabela.

\section{3- Análise microscópica morfológica dos grupos controle e experimental}

A partir das amostras submetidas à desmineralização em EDTA, foram confeccionadas lâminas de vidro coradas com HE para a análise microscópica geral. Esta análise morfológica foi descritiva e incluiu parâmetros microscópicos quanto:

- à junção dentogengival, incluindo os revestimentos epiteliais da mucosa gengival, sulcular e juncional, ou da bolsa periodontal, 
analisando-se integridade, extensão e relação do epitélio juncional com a junção cemento-esmalte. Avaliaram-se ainda a presença de hiperplasia epitelial e de exocitose, bem como o tecido conjuntivo subjacente, representado pelo ligamento gengival, quanto à hiperplasia e dilatação dos vasos sangüíneos, intensidade (leve, moderado e intenso), distribuição e tipo (mono ou polimorfonuclear) de infiltrado inflamatório, bem como sua proximidade com o epitélio juncional ou da bolsa periodontal;

- ao ligamento periodontal, analisando-se a integridade das fibras bem como intensidade (leve, moderado e intenso), distribuição e tipo (mono ou polimorfonuclear) de infiltrado inflamatório e presença de restos epiteliais de Malassez;

- a presença de reabsorção dentária e da crista óssea alveolar;

- a presença e quantidade (pouco ou exuberante) de biofilmes microbianos.

As lâminas de vidro coradas com $\mathrm{HE}$ obtidas a partir das amostras de tecido gengival também foram avaliadas microscopicamente. Esta análise morfológica foi descritiva e incluiu praticamente os mesmos parâmetros microscópicos citadoe anteriormente, exceto a presença de reabsorção dentária e da crista óssea alveolar.

A marcação histoquímica para a avaliação e posterior quantificação de mastócitos foi realizada a partir de cortes de amostras gengivais medindo $5 \mu \mathrm{m}$ de espessura desparafinizados e hidratados com água. Em seguida, as lâminas foram incubadas com solução de AT a 1\% (Synth, A1111.01.AD, São Paulo-Brasil), diluída em tampão fosfato ( $\mathrm{pH}=4,0$ a 6,0) por $2 \mathrm{~min}$. Após lavagem em tampão fosfato por 1 minuto, os cortes foram rapidamente desidratados em álcool 95\% e em acetona p.a., por 1 
minuto, e lavados em xilol, sendo posteriormente montados em resina sintética (Permount).

\section{4- Análise quantitativa dos mastócitos}

Os mastócitos marcados com AT foram quantificados por meio de análise histomorfométrica, utilizando-se microscópico binocular AXIOLAB-ZEISS associado a ocular com retículo de integração quadrado em forma de rede (Carl Zeiss, Alemanha- 4740680000000-Netzmikrometer 12,5x). Foi utilizada uma objetiva de 40x para a contagem, sendo a medida do lado do retículo de integração obtida por meio de uma lâmina milimetrada, que correspondeu a 0,31 mm. A área do retículo (A) foi determinada pela expressão matemática: $A=L$ x L, o que resultou em $A=0,0961 \mathrm{~mm}^{2}$.

A partir da obtenção de dois fragmentos de tecido gengival (vestibular e lingual), como detalhado anteriormente (Metodologia; 3.1Animais e Protocolo de Indução da Doença Periodontal), a análise microscópica se concentrou em três regiões: uma superficial (região 1), incluindo as regiões adjacentes aos epitélios sulcular e juncional ou da bolsa periodontal, bem como a área de inserção conjuntiva, e a outra profunda, delimitada pela visualização de tecido muscular nos cortes examinados. A região profunda foi, ainda, subdividida em subjacente ao epitélio juncional ou da bolsa periodontal (região 2) ou ao epitélio da mucosa bucal (região 3). Tanto na região superficial quanto na região profunda subjacente ao epitélio juncional ou da bolsa periodontal, um total de 4 campos microscópicos consecutivos foram analisados, enquanto que na região profunda subjacente ao epitélio da mucosa gengival, observaram-se 2 campos microscópicos consecutivos, devido ao tamanho restrito da região (Figura 3). 
Foi, então, registrado o número total de mastócitos encontrados em cada uma das três regiões separadamente e este dividido pelo número de campos observados (4 ou 2), de acordo com a região, obtendo-se a média de mastócitos por região. Em seguida, para se determinar o número de mastócitos por milímetro quadrado $\left(\mathrm{mm}^{2}\right)$, os valores médios foram divididos pela área do retículo $\left(0,0961 \mathrm{~mm}^{2}\right)$. Esta análise foi feita uma vez, por 3 examinadores (C, A e P), no intuito de se avaliar o erro interexaminadores, que foi calculado dois a dois, para cada região (1 , 2 e 3; lados vestibular e lingual) dos tecidos controle e doente, independente do período de indução da doença periodontal inflamatória por ligadura.

\section{5-Análise por RT-PCR}

\subsection{1- Extração de RNA Total de Tecidos Gengivais}

Para extração do RNA total contido nas amostras referentes à terceira etapa experimental, utilizou-se o método guanidino-isotiocianatofenol-clorofórmio ${ }^{39}$. Logo após a remoção do tecido gengival, este foi armazenado em tubos de microcentrífuga contendo $800 \mu \mathrm{L}$ de TRIzol e congelado a $-80^{\circ} \mathrm{C}$. Para disrupção e homogeneização do tecido gengival, foram utilizados tesoura de ponta fina e homogenizador de tecidos (Scientific Specialties Incorporated, Lodi, CA, Estados Unidos) previamente friccionados e embebidos em água tratada com dietil pirocarbonato (DEPC; Sigma) (0,1\% volume/volume). Obtido o tecido lisado, acrescentou-se ao tubo $20 \%$ do volume de clorofórmio $(160 \mu \mathrm{L})$, realizou-se agitação vigorosa e em seguida os tubos foram mantidos em repouso a $4^{\circ} \mathrm{C}$ por $5 \mathrm{~min}$, procedendo uma centrifugação a $1200 \mathrm{~g}$, por $25 \mathrm{~min}$, a $4{ }^{\circ} \mathrm{C}$, para separação das fases. A camada superior ou fase aquosa (cerca de $300 \mu \mathrm{L}$ ) foi, logo após, 
cuidadosamente recuperada e transferida para um novo tubo, ao qual foi adicionado o mesmo volume de isopropanol, sofrendo novamente agitação vigorosa, seguida por incubação em gelo por $15 \mathrm{~min}$, para precipitação do RNA. Após centrifugação a 1500 g, por $20 \mathrm{~min}$, a $4^{\circ} \mathrm{C}$, descartou-se, cuidadosamente, o sobrenadante e adicionou-se $1 \mathrm{~mL}$ de etanol 70\% (em água tratada com DEPC), agitando-se vigorosamente e centrifugando-se o tubo durante $10 \mathrm{~min}$ a $1500 \mathrm{~g}$, a $4^{\circ} \mathrm{C}$. O sobrenadante foi, novamente, descartado, e a lavagem e a centrifugação repetidas. Após descarte do último sobrenadante, os tubos foram deixados abertos e invertidos sobre um papel de filtro em temperatura ambiente, dentro do fluxo laminar, por 5 min para permitir a secagem das amostras. Para redissolver o RNA total, os tubos de microcentrífuga receberam um volume de $50 \mu \mathrm{L}$ de água tratada com DEPC e foram mantidos em estufa a $65^{\circ} \mathrm{C}$ por 15 a $30 \mathrm{~min}$ até a dissolução dos precipitados. As amostras de RNA total foram, então, mantidas a $-80^{\circ} \mathrm{C}$ até o momento do uso.

\subsection{2- Tratamento do RNA extraído com DNase}

Para que fosse evitada a possibilidade de contaminação do RNA total extraído das amostras gengivais por DNA genômico, procedeu-se o tratamento de todas as amostras com DNase durante $15 \mathrm{~min}$ em temperatura ambiente. Este procedimento foi realizado seguindo-se as orientações do fabricante do RNeasy mini kit, detalhadas em "RNase FREE DNase SET"182.

\subsection{3- Quantificação do RNA total}

A concentração de RNA total nas amostras foi determinada por diluição do RNA (1:250 em água destilada) e leitura em cubetas de quartzo 
em espectrofotômetro (Amersham Pharmacia) no comprimento de onda de $260 \mathrm{~nm}$. A fórmula para calcular a concentração de RNA total foi a seguinte: [RNA] $=\mathrm{A}_{260} \times 40 \times 250$ (fator de diluição), sendo o resultado expresso em $\mu \mathrm{g} / \mathrm{mL}$.

\subsection{4- Avaliação da qualidade do RNA total}

A qualidade do RNA total nas amostras foi determinada a partir da diluição do RNA (1:250 em Tris- $\mathrm{HCl} 10 \mathrm{mM}, \mathrm{pH}=$ 7,8) e leitura em cubetas de quartzo em espectrofotômetro nos comprimentos de onda de 260 e $280 \mathrm{~nm}$. Observou-se a relação $\mathrm{A}_{260} / \mathrm{A}_{280}$, a qual foi considerada aceitável se estivesse entre 1.9 e 2.1, pois valores nesse intervalo indicam ausência de DNA na amostra.

\subsection{5- Reação de RT-PCR}

O DNA complementar (cDNA) foi sintetizado através de uma reação de transcrição reversa (First-strand cDNA synthesis kit, Amersham Pharmacia), num volume final de reação de $15 \mu \mathrm{L}$ utilizando-se 1,8 $\mu \mathrm{g}$ de RNA total. Foi preparada uma mistura, no fluxo laminar, com todos os reagentes necessários para a RT-PCR: 0,2 $\mu \mathrm{g}$ de hexadeoxinucleotídeos, tampão para RT (concentrações finais: Tris- $\mathrm{HCl} 45 \mathrm{mM}$ pH= 8,3; $\mathrm{KCl} 68 \mathrm{mM}$ e $\mathrm{MgCl}_{2} 9 \mathrm{mM}$ ), soroalbumina bovina 0,08 mg/mL, DTT $15 \mathrm{mM}$, dNTPs 1,8 $\mathrm{mM}$ e $150 \mathrm{U}$ de transcriptase reversa. Esta mistura foi aliquotada $(8 \mu \mathrm{L})$ nos tubos de microcentrífuga, seguido da adição do RNA e água livre de DNAse e RNAse para completar um volume de $7 \mu \mathrm{L}$. Para a síntese do cDNA, os tubos com as amostras foram colocados em termociclador (Progene, modelo FPROGO5D, Techne, Cambridge, Inglaterra) durante um período de $60 \mathrm{~min}$ 
de incubação a $37^{\circ} \mathrm{C}$ e a reação foi paralisada pelo aquecimento a $90^{\circ} \mathrm{C}$ por 5 $\min$.

\subsection{6- PCR e detecção de produtos amplificados em gel de agarose}

Os produtos da RT $(3 \mu \mathrm{L})$ serviram de molde para a amplificação por PCR. Todas as reações foram realizadas num volume de 50 $\mu \mathrm{L}$ em tubos Hot start com os seguintes reagentes: 20 pmol $(0,4 \mu \mathrm{M})$ de cada primer (sense e anti-sense para cada alvo -Tabela A), tampão para PCR (concentrações finais: Tris- $\mathrm{HCl} 20 \mathrm{mM} \mathrm{pH=8,4;} \mathrm{KCl} 50 \mathrm{mM} \mathrm{e} \mathrm{MgCl}_{2}$ 1,5 mM), dNTPs $(0,2 \mathrm{mM})$ e 2,5 U de Taq DNA polimerase (Labtrade do Brasil Ltda, São Paulo, SP, Brasil). O processo de ciclagem térmica consistiu de desnaturação inicial por 2 min a 95 $\mathrm{C}$ seguida de 40 ciclos de amplificação. Para os alvos MMP-2, MMP-9 e os genes de expressão constitutiva $\beta$-actina e GAPDH, cada ciclo consistiu de desnaturação por $30 \mathrm{~s}$ a $95^{\circ} \mathrm{C}$, anelamento por $30 \mathrm{~s} \mathrm{a} 60^{\circ} \mathrm{C}$ e extensão por $1 \mathrm{~min} 30 \mathrm{~s} \mathrm{a} 72^{\circ} \mathrm{C}$. Para o alvo iNOS, alterou-se somente o tempo de anelamento para $60 \mathrm{~s}$. Após o término do último ciclo, as amostras foram incubadas por um período adicional de $10 \mathrm{~min}$ a $72{ }^{\circ} \mathrm{C}$ (extensão final). Para cada par de primers realizou-se PCR em água estéril para avaliação de sua possível contaminação (controle água) e para cada tecido-alvo a PCR também foi realizada utilizando-se RNA como molde para avaliação de possível contaminação por DNA genômico (no-RT). 
Tabela A - Primers utilizados na PCR para os diferentes alvos e tamanhos antecipados dos produtos de amplificação.

\begin{tabular}{|c|c|c|c|}
\hline Alvo & $\begin{array}{c}\text { Tamanho } \\
\text { Antecipado }\end{array}$ & $\begin{array}{l}\text { Sense } \\
\left(5^{\prime}-3^{\prime}\right)\end{array}$ & $\begin{array}{c}\text { Anti-sense } \\
\left(5^{\prime}-3^{\prime}\right)\end{array}$ \\
\hline$\beta$-actina ${ }^{194}$ & $351 \mathrm{pb}$ & aaccgcgagaagatgacccagatcatgttt & agcagccgtggccatctcttgctcgaagtc \\
\hline GAPDH $^{146}$ & $295 \mathrm{pb}$ & gaagggtggggccaaaag & ggatgcagggatgatgttct \\
\hline $\mathrm{iNOS}^{146}$ & $376 \mathrm{pb}$ & agagagatccggttcaca & cacagaactgagggtaca \\
\hline MMP-253 & $567 \mathrm{pb}$ & catcgctgcaccatcgeccatcat & cccagggtccacagctcatcatcatcaaag \\
\hline MMP-9139 & $241 \mathrm{pb}$ & ggattacctgtaccgctatggtta & ttggatccaataggtgatgttatg \\
\hline
\end{tabular}

Para detecção dos produtos amplificados de tamanhos antecipados, uma alíquota de $9 \mu \mathrm{L}$ de cada amostra foi analisada por eletroforese em gel de agarose a 2 \% (0,8 g de agarose em $40 \mathrm{~mL}$ de tampão TAE 1x) (Sigma) corado com brometo de etídeo $(0,5 \mu \mathrm{g} / \mathrm{mL})$. A eletroforese foi feita a 100V, por $160 \mathrm{~min}$, em uma cuba de eletroforese horizontal (Horizon 20-25, Gibco BRL Life Technologies), e o cDNA visualizado sob luz ultra-violeta em um transiluminador (T2202, Sigma Chemical Company, Estados Unidos). O peso molecular dos produtos da PCR foi determinado pela comparação com um marcador de peso molecular de tamanhos conhecidos (Low DNA mass ladder, Invitrogen Life Technologies, Estados Unidos). A fotodocumentação dos géis de agarose com os produtos amplificados pela PCR foi realizada com a utilização do aparelho EDAS 290 (Kodak, Estados Unidos) no laboratório do Prof. Dr. Fernando de Queiróz Cunha, do Departamento de Farmacologia da Faculdade de Medicina de Ribeirão Preto, da Universidade de São Paulo. Todos os outros experimentos foram realizados no laboratório da Disciplina de Farmacologia da Faculdade de Odontologia de Bauru, da Universidade de São Paulo, sob a orientação do Prof. Dr. Carlos Ferreira dos Santos. 


\subsection{7- Análise da Intensidade da Expressão de $R \mathbf{N A}$ mensageiro $\left(R N A_{m}\right)$}

Para avaliação da intensidade de expressão de RNA $_{m}$ em cada amostra de tecido gengival foi realizada uma análise semi-quantitativa, a partir do software Gel-Pro Analyzer (Media Cybernetics Inc, Silver Spring, MD, Estados Unidos), seguindo-se as orientações do fabricante e utilizando-se como parâmetro de comparação os valores de intensidade obtidos para a $\beta$ actina e GAPDH, proteínas cujos genes são expressos constitutivamente. Para cada amostra foi obtida uma relação entre a intensidade da banda alvo (MMP-2, MMP-9 e iNOS) e a das bandas de $\beta$-actina e/ou GAPDH no gel de agarose. Esta relação foi posteriormente utilizada para a comparação da expressão dos $\mathrm{RNA}_{\mathrm{m}}$ alvo entre amostras de tecido gengival sadio e afetado pela doença periodontal inflamatória.

\section{6- Análise Estatística}

Para a determinação do erro casual inter-examinadores com relação à análise quantitativa das células AT-positivas por $\mathrm{mm}^{2}$ (mastócitos $/ \mathrm{mm}^{2}$ ), utilizou-se o cálculo de erro proposto por Dahlberg95, calculado dois a dois, cuja fórmula é:

$$
\begin{aligned}
\text { erro }=\sqrt{\frac{\sum \mathrm{d}^{2}}{2 \mathrm{n}}} & \\
\text { onde, } \mathrm{d} & =\text { diferença entre os examinadores } \\
\mathrm{n} & =\text { número de casos }
\end{aligned}
$$

Em seguida, as médias dos números dos mastócitos $/ \mathrm{mm}^{2} \mathrm{e}$ respectivos desvios-padrão (d.p.) das médias, observados em cada período de indução experimental, foram analisados por meio de Análise Estatística 
Descritiva, para a comparação entre as 3 regiões (1, 2 e 3), assim como para uma comparação geral entre tecidos controle e doente, independente do período de indução, utilizando-se o teste não paramétrico de Wilcoxon.

Os valores obtidos pela análise com o programa Gel-Pro Analyzer foram apresentados como média \pm erro padrão da média, em relação à expressão de $\beta$-actina. A significância das diferenças e valores medidos no mesmo animal foi avaliada por meio de ANOVA de dois critérios (condição -saúde ou doença periodontal inflamatória- x período), com medidas repetidas em um fator (período). Posteriormente, as diferenças significativas foram analisadas pelo post hoc de Tukey.

Para todas as análises, $\mathrm{o}$ valor de $P$ foi considerado estatisticamente significante quando menor do que 0,05. 


\section{4- RESULTADOS}

\section{1- Análise macroscópica clínica}

De acordo com os parâmetros previamente mencionados, a análise clínica dos primeiros molares inferiores direito e seus tecidos periodontais adjacentes revelou grande quantidade de placa dentobacteriana aderida aos dentes com ligadura, especialmente no nó mesial, tornando-se cada vez mais exuberante com o aumento do tempo de indução experimental (Figura 4). Os aspectos inflamatórios do tecido gengival, como aumento volumétrico e sangramento apresentaram-se em diferentes intensidades, porém não tão consideravelmente presentes como geralmente ocorre na doença periodontal inflamatória humana. Após 1 e 3 dias de indução, o aumento volumétrico e o sangramento, especialmente na região vestibular, estavam geralmente associados a pequenas áreas ulceradas, compatíveis com trauma transoperatório no local, e a um certo grau de mobilidade dentária, sendo todos esses sinais provavelmente relativos à cirurgia para colocação do fio. Somente se observou sangramento significativo ao toque, utilizando-se de um instrumento sem ponta ativa, a partir do 7o dia de indução experimental. A Tabela B resume as características clínicas observadas em cada rato (1, 2 e 3$)$ de cada período, classificando-as com relação a escores (+: discreto; ++: moderado; +++: intenso; ++++: muito intenso) e, quando necessário, de acordo com a localização (V: vestibular; L: lingual). 

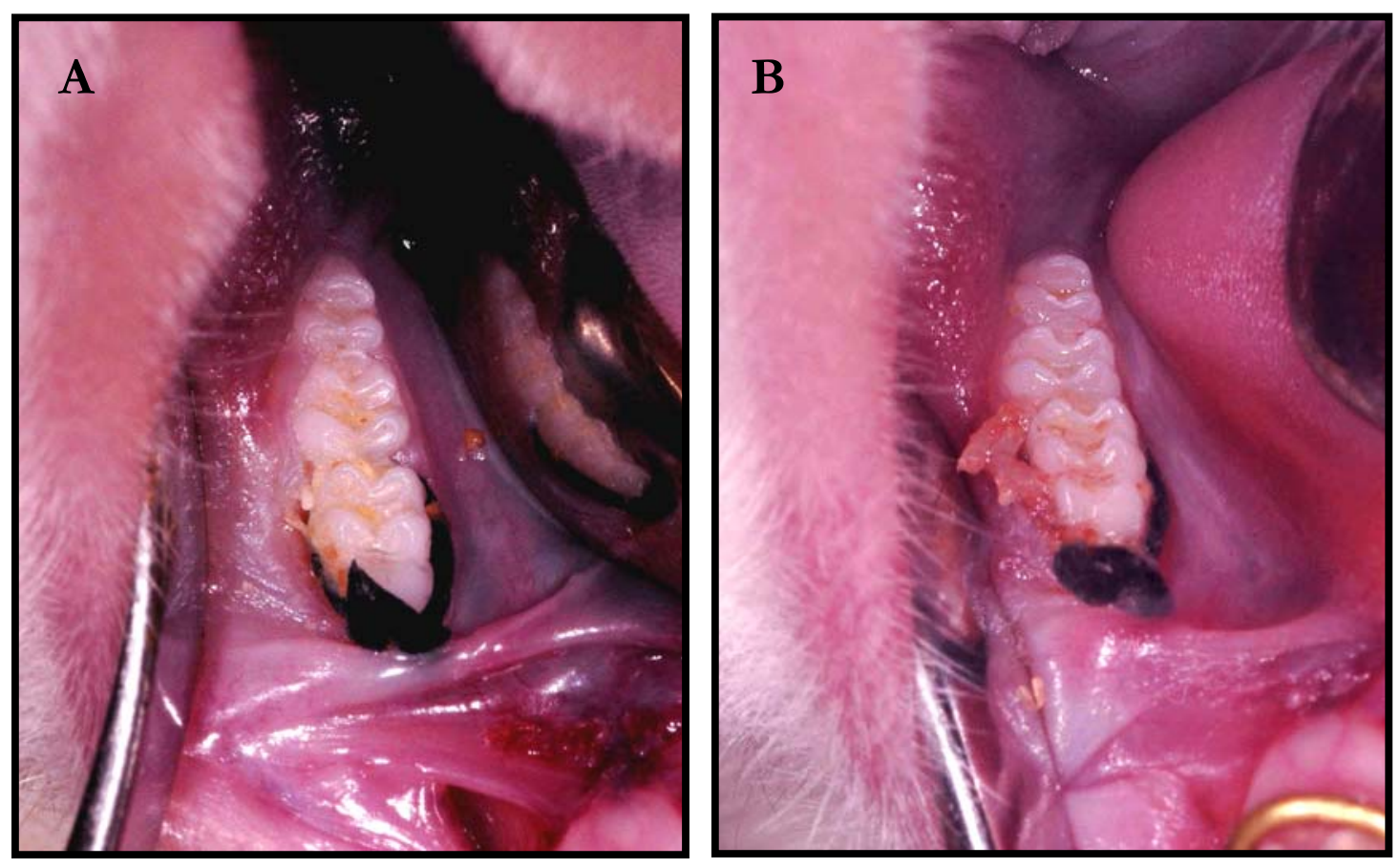

Figura 4: Grande quantidade de placa dentobacteriana aderida aos dentes com ligadura, especialmente no nó mesial, tornando-se cada vez mais exuberante com o aumento do tempo de indução experimental (3-A, 7-B e 30-C dias). Em contraste, a ausência de placa dentobacteriana do lado controle (D).
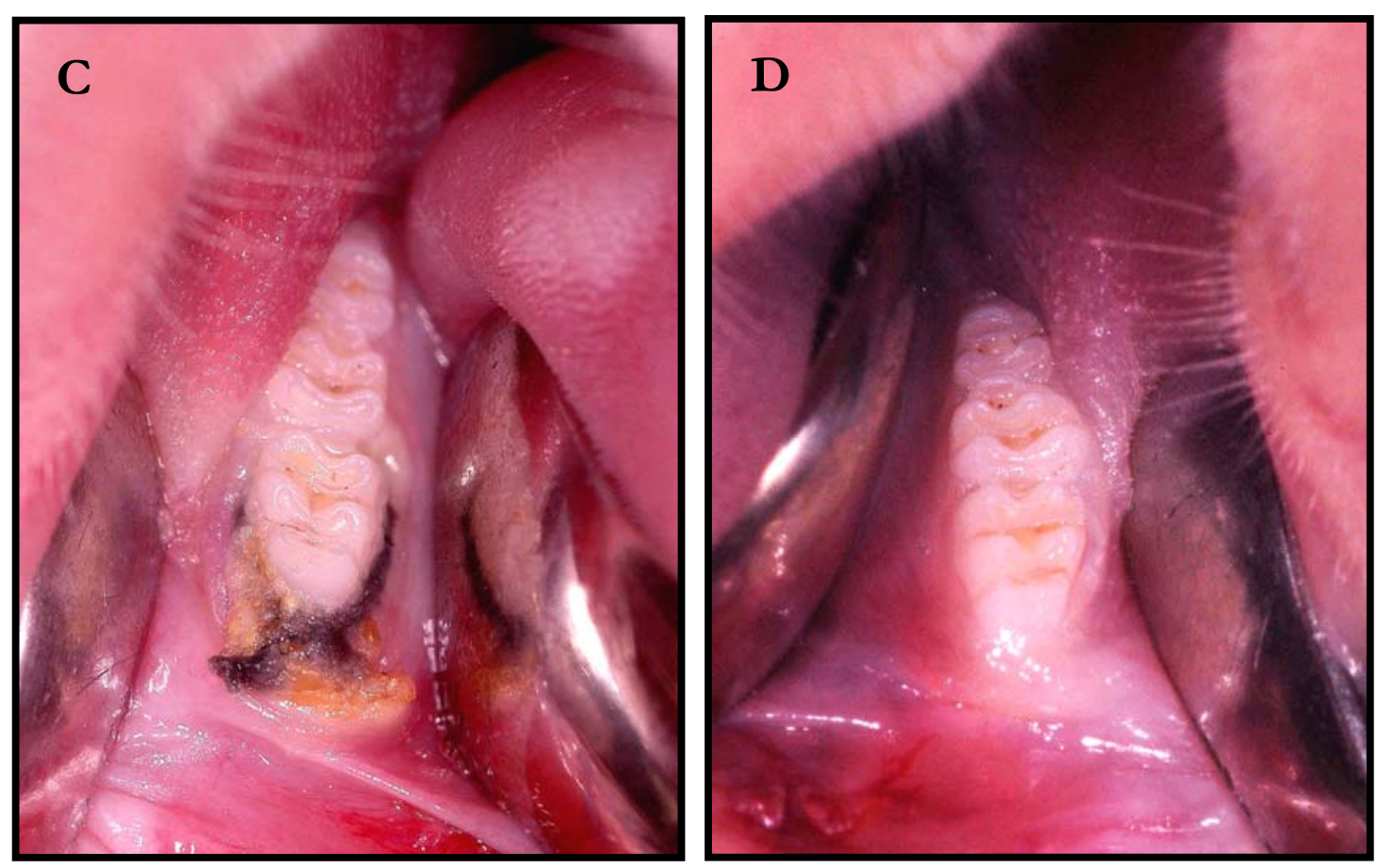
Tabela B: Características clínicas, em relação ao primeiro molar inferior direito e seus tecidos periodontais, observadas em cada rato (1, 2 e 3) de cada período, classificadas com relação a escores (+: discreto; ++: moderado; +++ : intenso; ++++ : muito intenso) e, quando necessário, de acordo com a localização (V: vestibular; L: lingual).

\begin{tabular}{c|ccccc}
\hline $\begin{array}{c}\text { Períodos } \\
\text { dia(s) }\end{array}$ & $\begin{array}{c}1 \\
\text { (ratos 1/2/3) }\end{array}$ & $\begin{array}{c}3 \\
(\operatorname{ratos} 1 / 2 / 3)\end{array}$ & $\begin{array}{c}7 \\
(\operatorname{ratos} 1 / 2 / 3)\end{array}$ & $\begin{array}{c}15 \\
(\operatorname{ratos} 1 / 2 / 3)\end{array}$ & $\begin{array}{c}30 \\
(\text { ratos 1/2/3) }\end{array}$ \\
\hline Parâmetros & & & & & \\
\hline 1 & $+/+/+$ & $++(\mathrm{V}) /+(\mathrm{V}) /-$ & $++/+/+$ & $+/-/-$ & $-/ /-$ \\
\hline 2 & $+/+/+$ & $+/+/-$ & $+/+/+$ & $-/-/-$ & $-/-/-$ \\
\hline 3 & $-++(\mathrm{L}) /-$ & $-/+(\mathrm{V}) /-$ & $+/+/+$ & $+/++/++$ & $+++/++/+$ \\
\hline 4 & $-/ /-$ & $-/-/-$ & $-/+/+$ & $-/-/-$ & $-/-/-$ \\
\hline 5 & $+/+/++$ & $++/++/++$ & $++/+++/+++$ & $+/++/+$ & $++/+++/+$ \\
\hline 6 & $+/-/-$ & $+/+/++$ & $+/+/+$ & $+++/++++/+++$ & $+++/++++++++$ \\
\hline
\end{tabular}

Legenda:

1- presença de pequenas áreas ulceradas compatíveis com trauma transoperatório

2- pseudomembrana recobrindo estas áreas

3- sangramento ao toque

4- aumento volumétrico gengival, compatível com edema tecidual

5- mobilidade dentária

6- presença de placa dentobacteriana aderida aos dentes com ligadura 


\section{2- Análise microscópica das amostras submetidas à desmineralização em EDTA}

\subsection{1- Tecidos periodontais normais (Esquema 1)}

Esquema 1: Representação do primeiro molar inferior esquerdo (controle) e de seus tecidos periodontais $(\mathrm{O}$ traçado descontínuo representa virtualmente a superfície do esmalte).

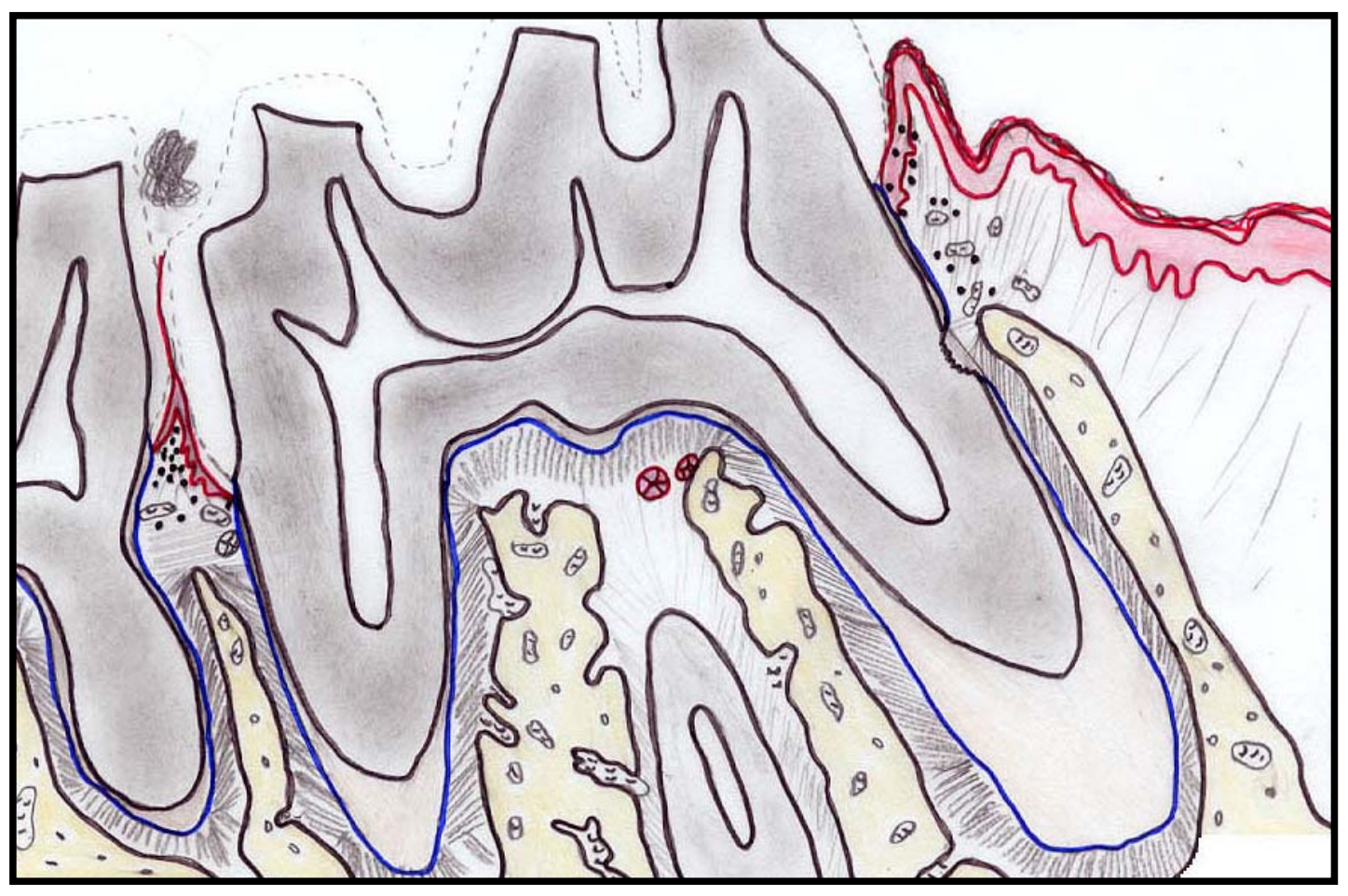

A estrutura e organização dos tecidos periodontais normais dos

molares dos ratos foram inicialmente avaliadas a partir das amostras controle obtidas do lado oposto à colocação da ligadura, mostrando-se muito semelhantes às dos humanos. Microscopicamente, identificou-se a presença de mucosa gengival revestida por epitélio pavimentoso estratificado, porém com espessa camada córnea, em continuidade com epitélio sulcular pavimentoso estratificado paraqueratinizado, que se continua como epitélio juncional. Este, por sua vez, era delgado, composto por células achatadas, apresentando superfície não queratinizada. Subjacente, observou-se tecido 
conjuntivo fibroso, composto por fibras colágenas, pequenos vasos sangüíneos e discreto infiltrado inflamatório PMN, muitas vezes no interior dos epitélios juncional e sulcular. Lateralmente, notou-se superfície dentária revestida por cemento. Nos planos mais profundos, observaram-se tecido conjuntivo fibroso, com inúmeros feixes organizados de fibras colágenas, e osso alveolar, em continuidade com tecido ósseo medular ricamente celularizado e vascularizado. Lateralmente ao osso alveolar, nas proximidades da superfície radicular, notou-se ligamento periodontal com fibroblastos apresentando morfologias variadas, alinhados ao longo de feixes bem definidos de fibras colágenas, possuindo extensos processos que envolvem estes feixes (Figura 5).

Com a evolução do tempo $(1,3,7,14,28,42$ e 56 dias após a indução experimental no lado oposto), não se observaram variações morfológicas significantes nos tecidos periodontais normais não submetidos à colocação da ligadura. Na região mesial, distinguiram-se os epitélios sulcular paraqueratinizado e juncional, este justaposto à área correspondente ao esmalte desmineralizado pela solução de EDTA, porém com discreta extensão apical, recobrindo a porção mais superficial do cemento. Notaramse, ainda, pequenas áreas de hiperplasia do epitélio juncional nessa região e freqüente exocitose discreta por PMNs (Figura 6A). Subjacente, o tecido conjuntivo fibroso encontrou-se ora sem inflamação ora com infiltrado inflamatório predominantemente $\mathrm{MN}$, com escassos PMNs neutrófilos, discreto e distribuído especialmente na região justa-epitelial. Notaram-se, ainda, vasos sangüíneos com discreta marginação leucocitária, especialmente por PMNs.

Na região interproximal distal ao primeiro molar, o epitélio juncional apresentou-se com hiperplasia, ora discreta ora moderada, e moderada exocitose por PMNs, em direção a agregados e biofilmes microbianos suprajacentes, muitas vezes exuberantes nesta região (Figuras 
6C e D). A inflamação, nesta área, restringiu-se à região subepitelial, mantendo-se a integridade das fibras gengivais, do ligamento periodontal e do osso alveolar.

Notaram-se, ainda, feixes de fibras colágenas altamente organizados na região do ligamento gengival, que ocasionalmente apresentava vasos sangüíneos congestos, de tamanhos variados, bem como células MNs de permeio, especialmente na região interproximal distal ao primeiro molar (Figuras 6C e D). Profundamente, o ligamento periodontal se caracterizou por espessura uniforme e grande celularidade, com fibroblastos de morfologia principalmente fusiforme, alguns ovalados e dispostos em fascículos. As fibras colágenas arranjavam-se paralelamente entre si e se inseriam perpendicularmente às superfícies óssea e cementária, sendo permeadas por inúmeros vasos sangüíneos, no entanto sem a presença de infiltrado inflamatório, compatível com a normalidade.

Com relação ao suporte ósseo, a crista óssea alveolar apresentou-se arredondada e a superfície óssea periodontal predominantemente revestida por osteoblastos justapostos e em paliçada, porém com áreas de superfície levemente irregular ao longo de todo o ligamento periodontal, revelando eventuais áreas de reabsorção óssea superficial, caracterizadas pela presença de lacunas de Howship e clastos justapostos à superfície, tanto na região mesial, quanto nas regiões de furca e distal, provavelmente relacionadas com a remodelação tecidual requerida pela dinâmica do espaço periodontal. Notaram-se, ainda, na face endosteal, espaços endosteais amplos e ricamente vascularizados. Embora a superfície cementária se apresentasse, em sua maioria, uniforme e regular, revestida por cementoblastos, foram observadas freqüentes áreas de reabsorção dentária paralisada e/ou de superfície irregular, demarcadas por uma linha de reversão basofílica com eventuais células poliédricas de natureza blástica, assumindo um arranjo grosseiro em paliçada, na superfície do tecido 
cementário (Figura 6B). Quando se observou o agrupamento entre essas células, relacionando-se diretamente com a superfície mineralizada do tecido, demarcada pela linha de reversão, resultando na aposição de tecido cementóide ou osteóide, caracterizou-se a reabsorção como reparada, também freqüentemente observada, em especial nas regiões mais cervicais (Figura 7A). Os achados microscópicos de reabsorção dentária paralisada foram especialmente evidentes em um dos casos, referente ao período de 3 dias, na região mesial, envolvendo praticamente toda a extensão radicular. Ainda com relação às suas raízes, embora o primeiro molar inferior apresente quatro (mesial, centro-lingual, centro-vestibular e distal), na maioria dos cortes microscópicos foi possível somente a visualização das duas raízes principais - a mesial, mais longa e retilínea, e a distal, levemente maior e mais inclinada ${ }^{215}$.

A análise microscópica revelou, ainda, a presença de eventuais corpúsculos eosinofílicos arredondados em íntima proximidade com o cemento, compatível com cementículos, além de ilhotas de epitélio odontogênico de variados tamanhos no ligamento periodontal, compatíveis com restos epiteliais de Malassez, distribuídas especialmente no terço cervical das regiões interproximal e inter-radicular do primeiro molar inferior dos ratos pertencentes aos grupos de 42 e 56 dias (Figura 7B). 


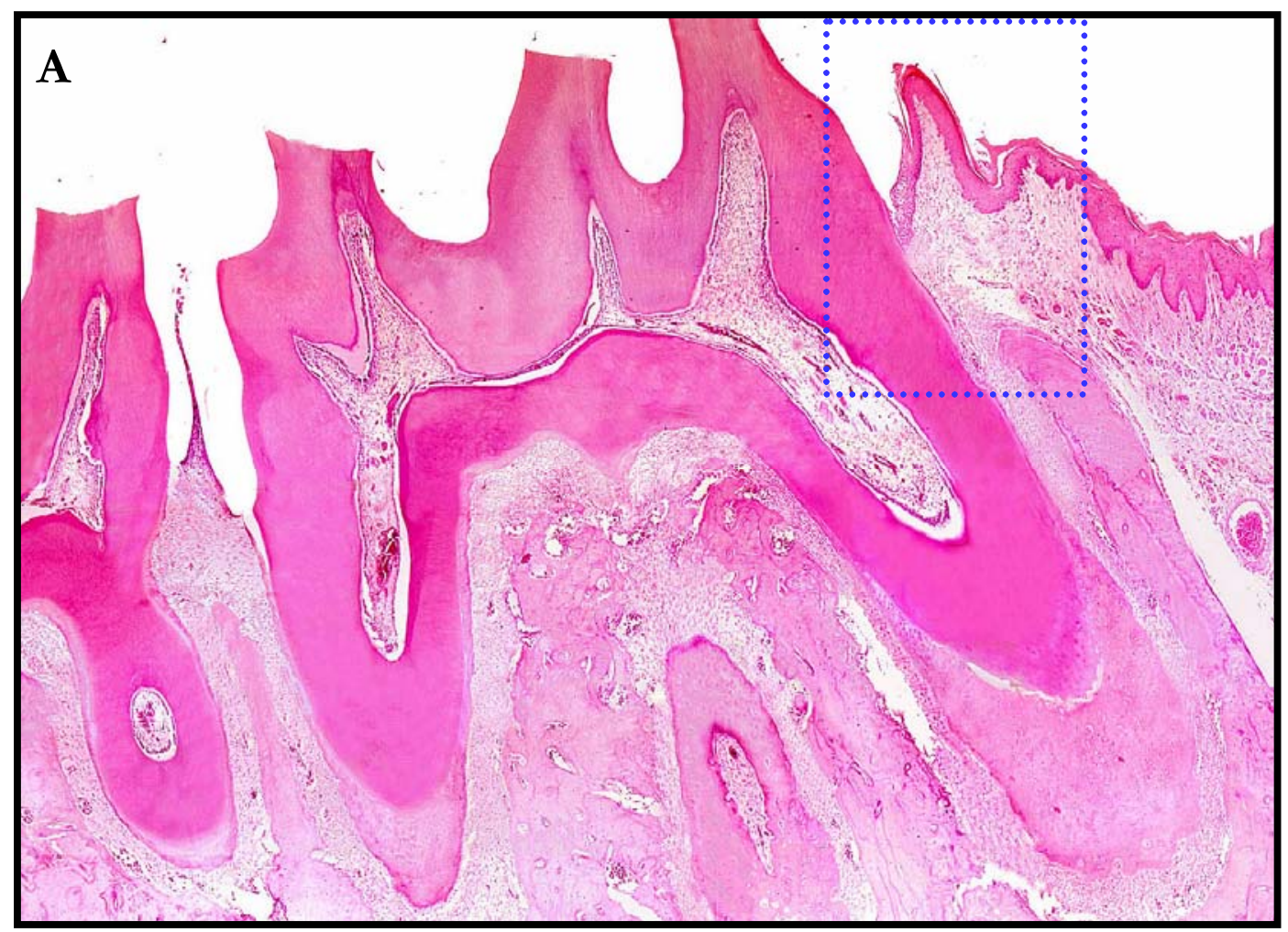

Figura 5: Vista panorâmica de um corte microscópico correspondente ao lado controle do período de 3 dias após indução experimental no lado oposto, ilustrando as relações entre dentes, ligamento periodontal e junção dentogengival (A). Esta, destacada em maior aumento em $\mathbf{B}$ (A e B: HE; aumentos originais de $25 \mathrm{x}$ ).

\section{Junção dentogengival}

EG: epitélio gengival

ES: epitélio sulcular

\section{EJ: epitélio juncional}

JCE: junção cemento-esmalte

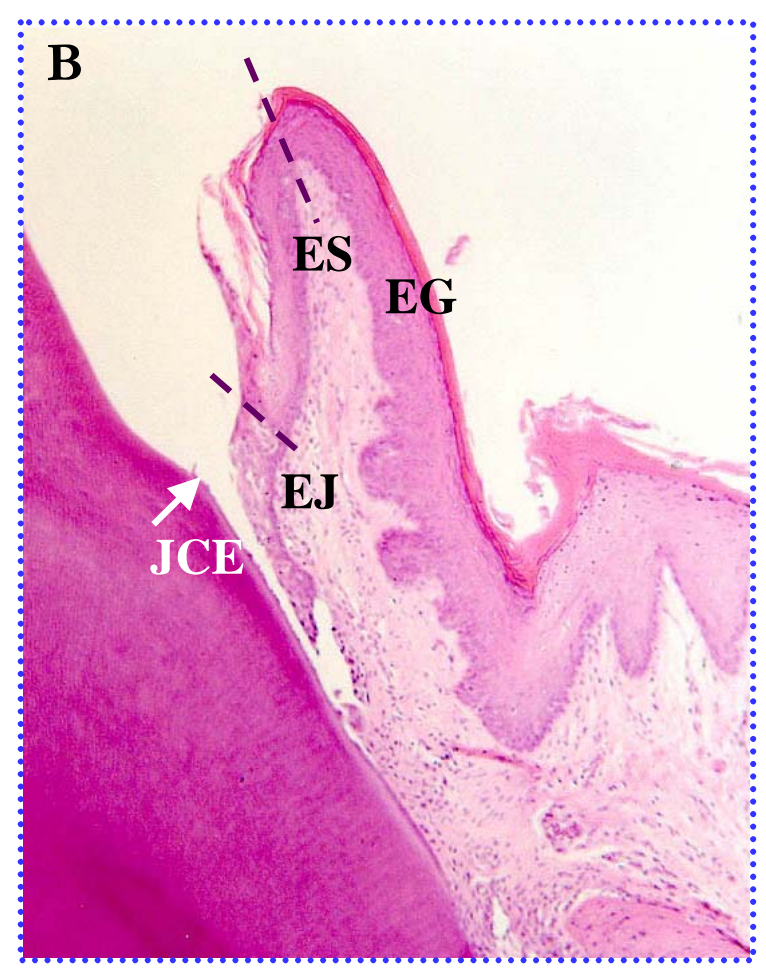



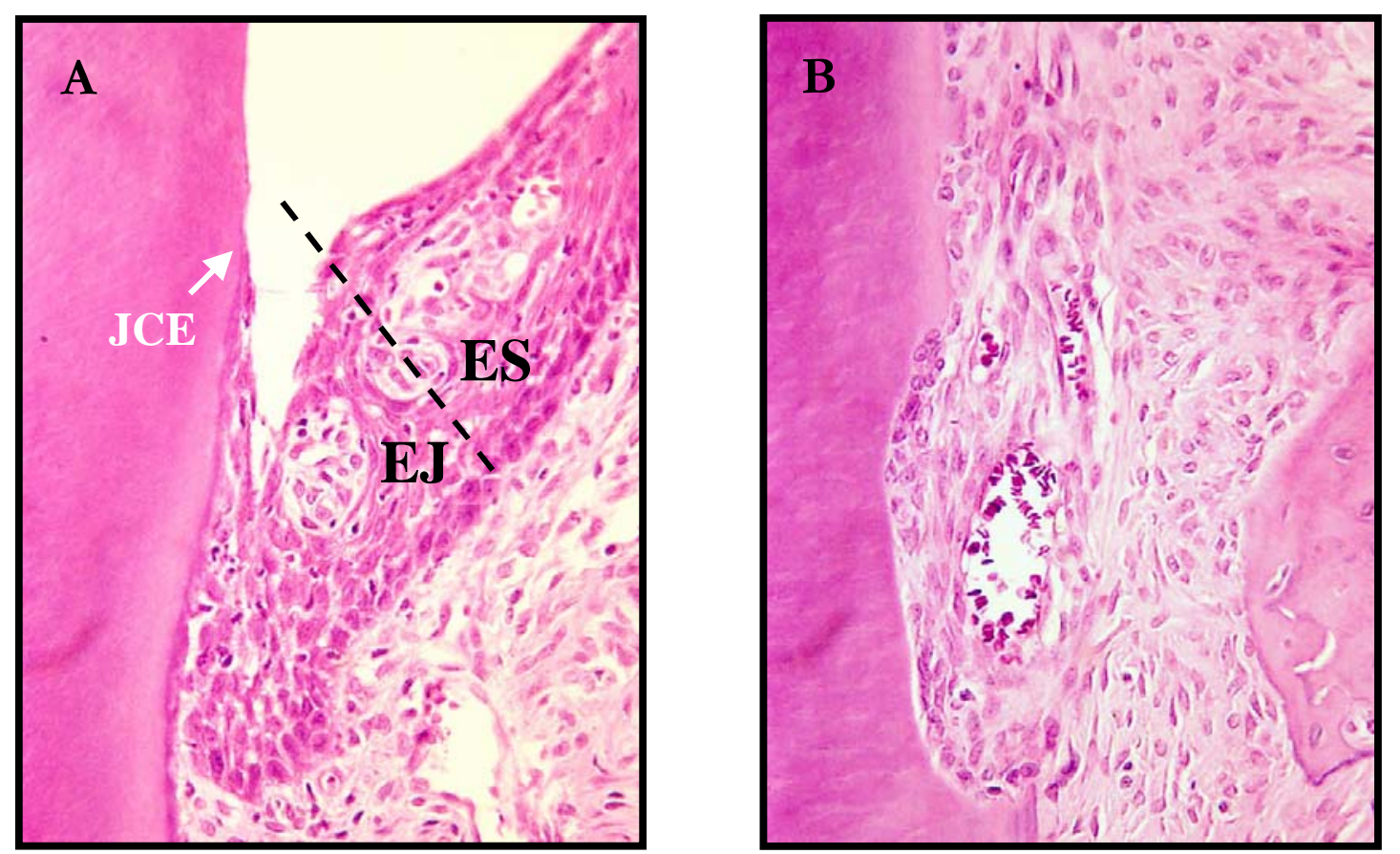

Figura 6: Região mesial do primeiro molar inferior do lado controle do período de 1 dia após indução experimental no lado oposto, exibindo discreta extensão apical do epitélio juncional, que recobre a porção mais superficial do cemento, bem como freqüente exocitose discreta por PMNs nesta região (A). Em B, nota-se área de reabsorção dentária paralisada e/ou de superfície irregular no mesmo dente. Em $\mathbf{C}$ e $\mathbf{D}$, note a região interproximal correspondente ao lado controle do período de 3 dias após indução experimental no lado oposto, revelando exocitose por PMNs, ora discreta (C) ora moderada (D), em direção a agregados e biofilmes microbianos suprajacentes, muitas vezes exuberantes nesta região $(\mathbf{A}, \mathbf{B}, \mathbf{C}$ e $\mathbf{D}$ : H.E.; aumentos originais de 100x $-\mathbf{A}$ e $\mathbf{B}$, e de 25x -C e $\mathbf{D} ; \mathbf{E S}=$ epitélio sulcular, $\mathbf{E J}=$ epitélio juncional, $\mathbf{J C E}=$ junção cemento-esmalte).
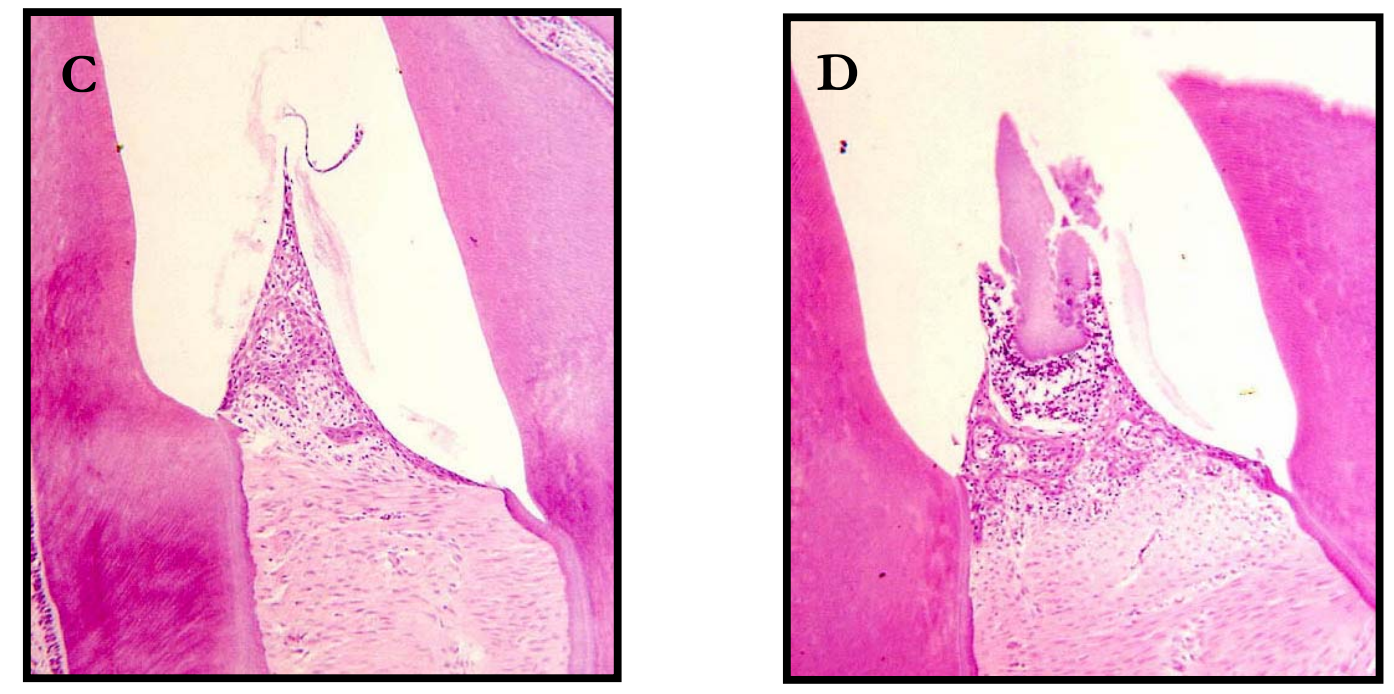


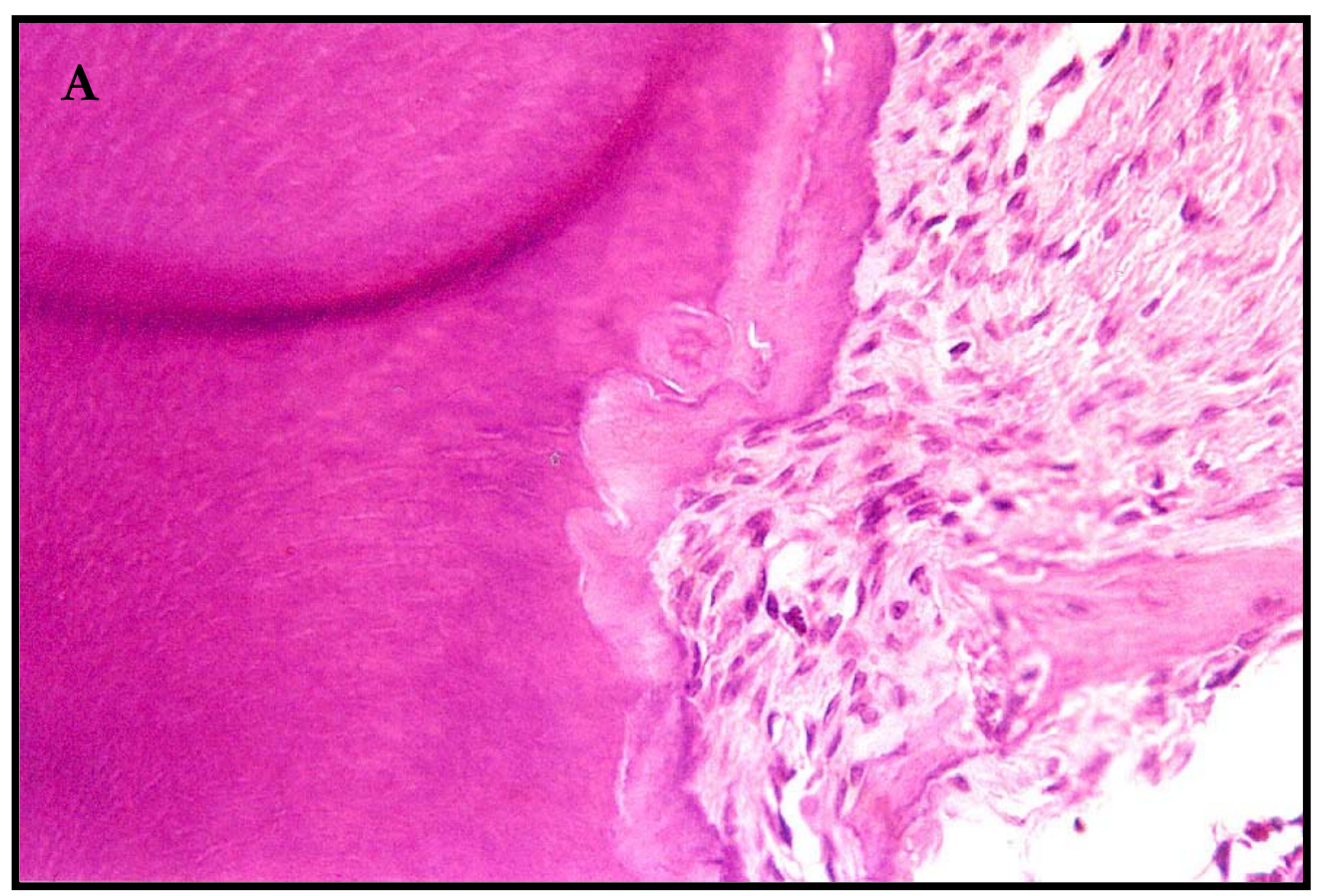

Figura 7: Em A, nota-se reabsorção dentária reparada caracterizada pelo agrupamento de células poliédricas de natureza blástica relacionando-se diretamente com a superfície mineralizada de tecido cementóide ou osteóide. Em B, observamse duas ilhotas de epitélio odontogênico no ligamento periodontal compatíveis com restos epiteliais de Malassez (A e B: HE; aumentos originais de 100x; lado distal do primeiro molar inferior esquerdo dos períodos de 1 e 3 dias após a indução experimental no lado oposto, respectivamente).

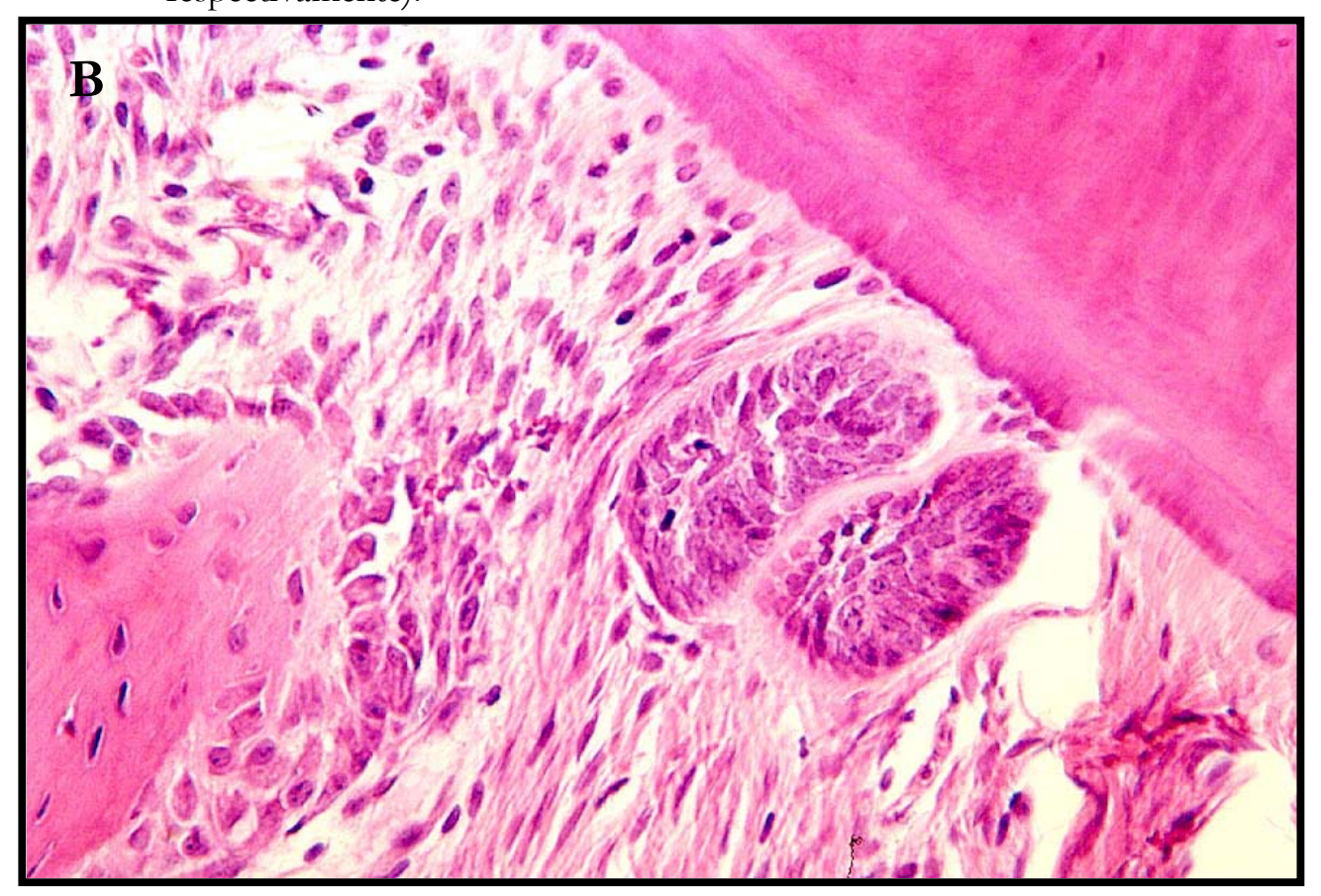




\subsection{2- Tecidos periodontais submetidos ao progressivo acúmulo de placa dentobacteriana por meio da colocação de ligadura}

A análise microscópica dos tecidos periodontais submetidos ao progressivo acúmulo de placa dentobacteriana por meio da colocação de ligadura revelou variações morfológicas significantes entre os diferentes períodos de indução $(1,3,7,14,28,42$ e 56 dias). Entre elas, foram observadas alterações patológicas gradativas no epitélio juncional, incluindo formação de projeções epiteliais, áreas ulceradas e eventualmente necrosadas, assim como exocitose por PMNs neutrófilos e migração apical progressiva, resultando em formação de bolsa periodontal. Além disso, de permeio ao tecido conjuntivo fibroso subjacente, observou-se intenso infiltrado inflamatório PMN, especialmente na região subepitelial, e $\mathrm{MN}$, mais difusamente distribuído. Os PMNs neutrófilos migravam em direção a agregados e biofilmes microbianos presentes na superfície dentária, desde os períodos mais precoces da doença periodontal inflamatória, enquanto as células MNs eram escassas e observadas somente a partir do período de 14 dias de indução experimental. Observou-se, ainda, proliferação vascular, destruição de fibras colágenas, bem como reabsorção do osso alveolar de suporte, especialmente a partir do 7o dia após a colocação da ligadura, quando a inflamação atingiu, mais evidentemente, o periodonto de sustentação, evoluindo para perda do suporte dentário, inclusive na região de furca (especialmente a partir do 14으 dia), culminando com a formação de seqüestros ósseos. Nas amostras analisadas, a progressão da doença periodontal inflamatória não foi marcada tanto pelo aumento de intensidade do infiltrado inflamatório, mas pela grande perda óssea nas regiões mais profundas do tecido periodontal de suporte.

A partir do 42o dia, o epitélio da bolsa periodontal manteve-se hiperplásico e com moderada exocitose por PMNs em direção a grande quantidade de agregados e biofilmes microbianos. Estes apresentaram 
aumento progressivo de sua extensão com o passar dos períodos, porém sua localização na superfície dentária se manteve. Em contraste, notou-se menor grau de inflamação no tecido conjuntivo subjacente ao longo do tempo.

Na região de furca, a partir do 14o dia, também se observou migração apical do epitélio da bolsa periodontal, resultando na formação de áreas de abscesso periodontal incipiente e de reabsorção óssea à distância, evoluindo para uma extensa área de abscesso periodontal nos períodos seguintes. A partir deste período, notou-se maior número de áreas de reabsorção dentária, nas quatro raízes do primeiro molar inferior.

Pôde-se observar, ainda, que o infiltrado inflamatório neutrofílico se distribuiu para planos mais profundos, de permeio às fibras musculares esqueléticas presentes na região mesial, principalmente nos períodos iniciais, até o 7o dia de indução experimental.

A seguir, os resultados serão expressos de forma descritiva e mais detalhada, considerando cada período da indução da doença periodontal inflamatória no primeiro molar inferior direito individualmente, bem como por meio de esquemas e fotomicrografias. 
+ Período de 1 dia (Esquema 2)

Esquema 2: Representação do primeiro molar inferior direito e de seus tecidos periodontais, após 1 dia da colocação da ligadura ( $O$ traçado descontínuo representa virtualmente a superfície do esmalte).

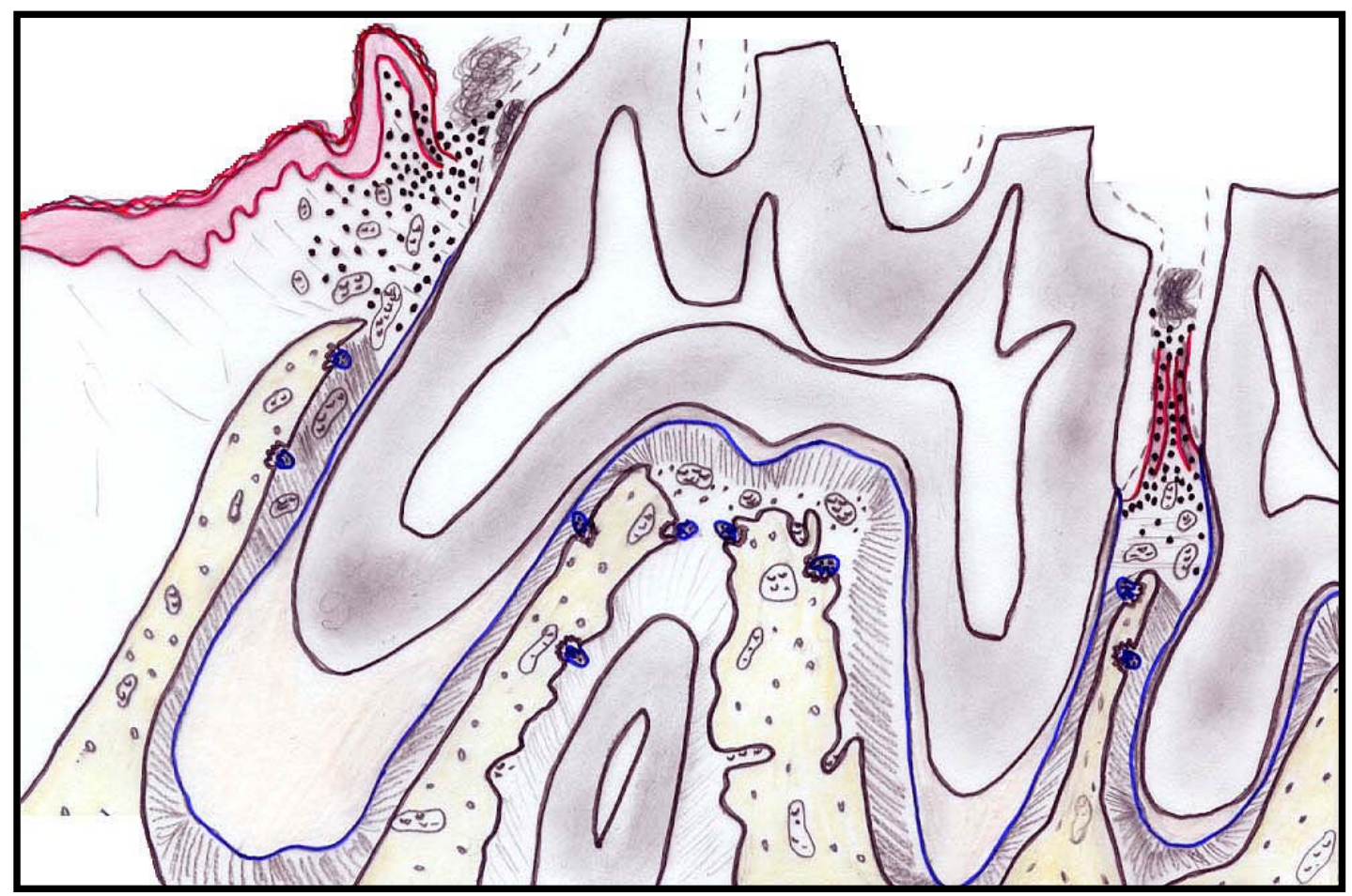

Os cortes microscópicos demonstraram mucosa gengival constituída por epitélio pavimentoso estratificado ortoqueratinizado.

$\mathrm{Na}$ região mesial, observou-se retração do tecido gengival causada pela presença do fio de seda, com destruição do epitélio juncional e da porção mais superficial do ligamento gengival, com discretas áreas de exposição de cemento, além de intensa exocitose por PMNs (Figuras 8A e B). Subjacente, observou-se tecido conjuntivo fibroso do ligamento gengival com vasos sangüíneos congestos repletos de PMNs em seu interior, localizados mais superficialmente e ao longo da crista óssea alveolar (Figura 8C), além de intenso infiltrado inflamatório predominantemente PMN, ora em contato com agregados e biofilmes microbianos superficiais e intra-epitelias ora 
estendendo-se em direção mesial e em proximidade com osso e cemento. Mais profundamente, o infiltrado inflamatório neutrofílico distribuiu-se próximo a fibras musculares esqueléticas, e notou-se crista óssea alveolar arredondada com maior parte de sua superfície recoberta por osteoblastos, porém com áreas eventuais de reabsorção óssea.

Na região de furca, destacou-se a presença de eventuais vasos sangüíneos congestos, discreto infiltrado inflamatório predominantemente neutrofílico localizado no terço cervical, além de freqüentes áreas de reabsorção óssea.

$\mathrm{Na}$ região interproximal distal ao primeiro molar, notou-se destruição do epitélio juncional e intenso infiltrado inflamatório PMN no tecido conjuntivo subjacente, estendendo-se para o terço cervical do ligamento periodontal, bem como para a região mesial do segundo molar adjacente. Observou-se, ainda, discreta exposição de cemento (Figura 8D) e freqüentes áreas de reabsorção óssea. 

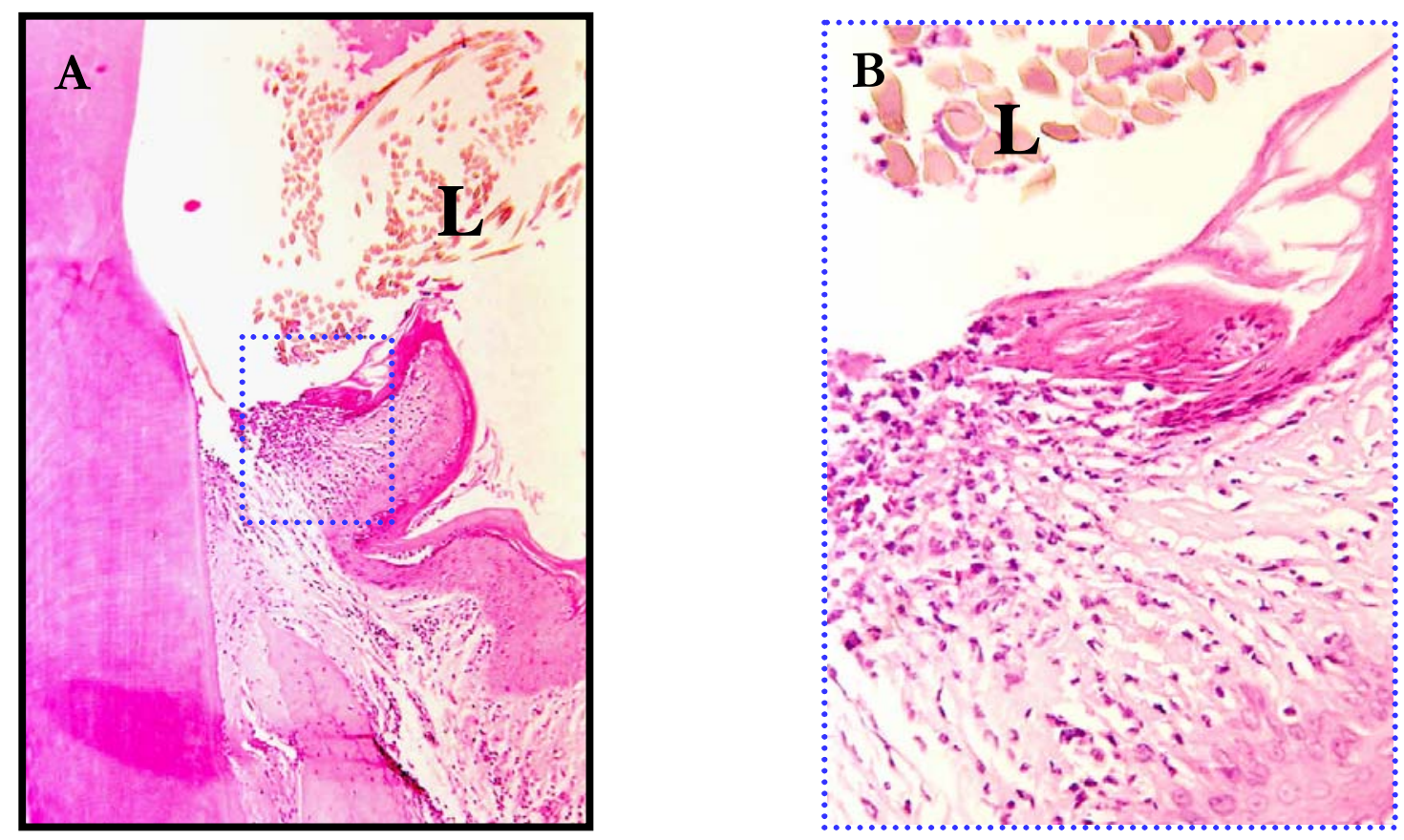

Figura 8: Ligadura (L) em posição no lado mesial, no interior do sulco gengival, com biofilmes microbianos aderidos (A). Em B, que corresponde ao maior aumento da área destacada em $\mathbf{A}$, note os inúmeros PMNs em exocitose e ao redor dos biofilmes microbianos. Observe, ainda, em $\mathbf{C}$, inúmeros vasos sangüíneos congestos repletos de PMNs no ligamento periodontal mesial, bem como a destruição do epitélio juncional e a intensa exocitose na região interproximal em $\mathbf{D}$ (A, B, C e D: HE; aumentos originais de 25x -A e $\mathbf{D}$ - e de 100x -B e C; período de 1 dia após a indução experimental).
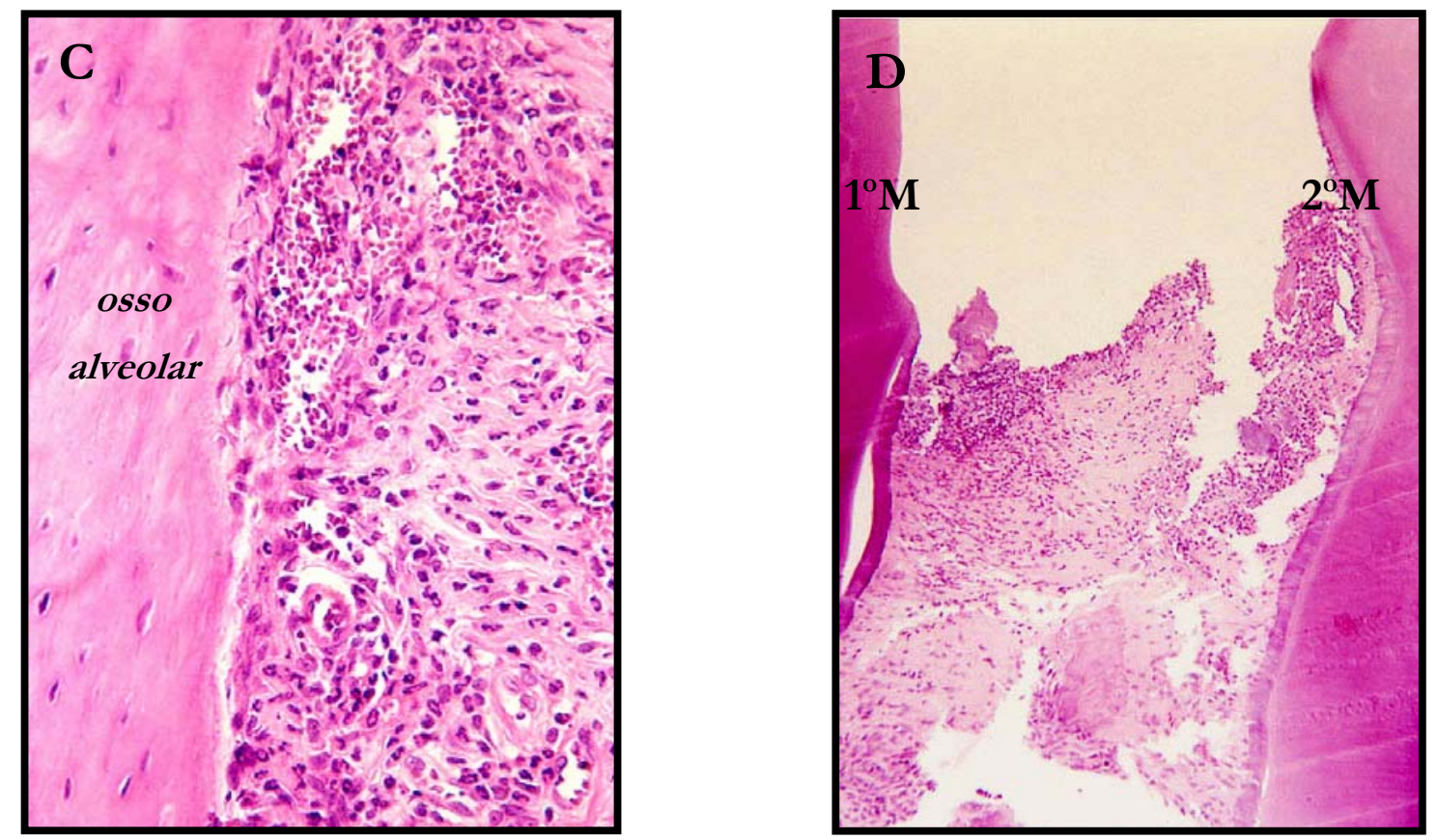


\section{tPeríodo de 3 dias (Esquema 3)}

Esquema 3: Representação do primeiro molar inferior direito e de seus tecidos periodontais, após 3 dias da colocação da ligadura (O traçado descontínuo representa virtualmente a superfície do esmalte).

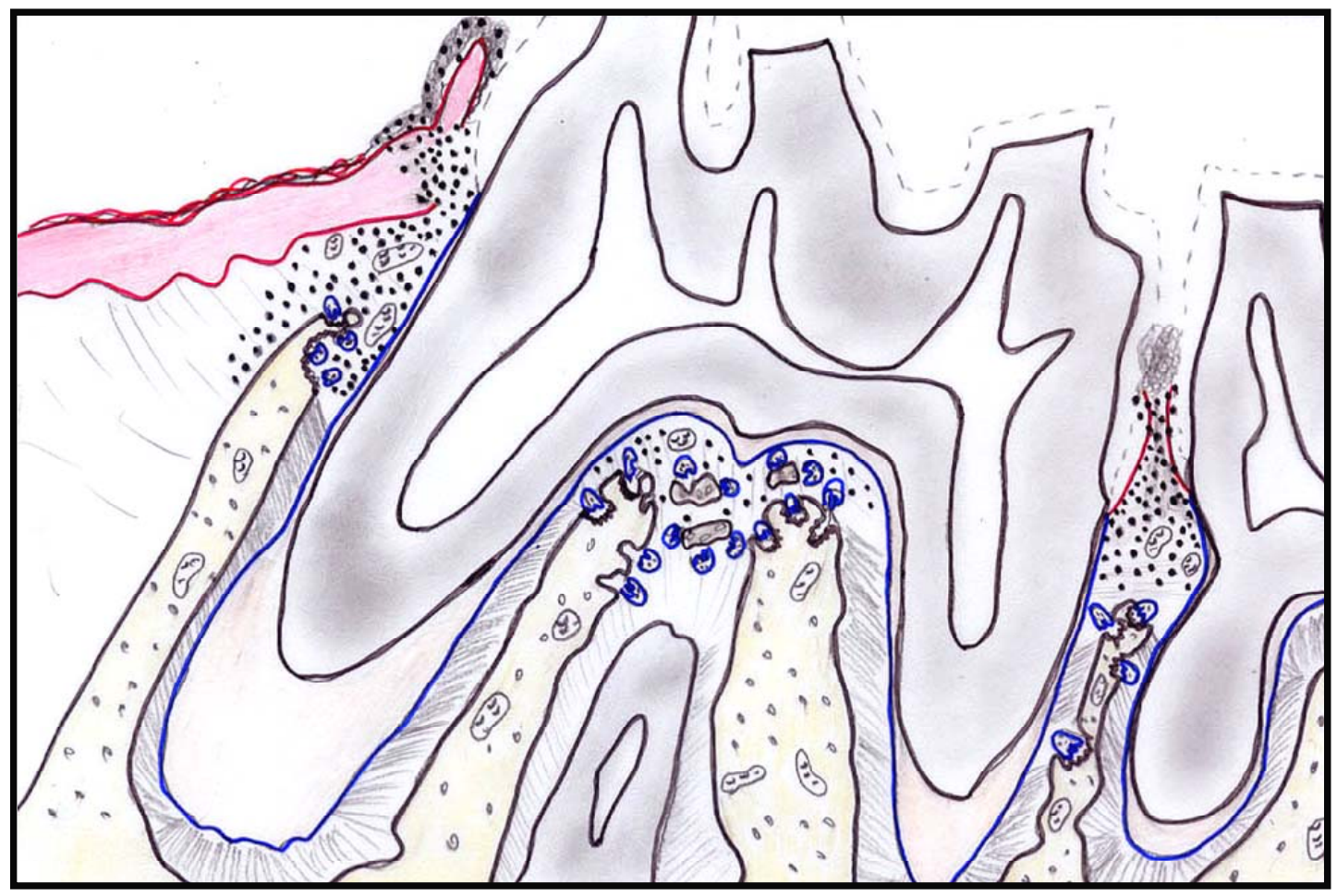

Os cortes microscópicos demonstraram mucosa gengival constituída por epitélio pavimentoso estratificado ora orto ora paraqueratinizado, com intensa exocitose por PMNs em direção a agregados e biofilmes microbianos exuberantes, bem como necrose superficial do epitélio na região mesial, que se encontrava adjacente ao cemento na superfície dentária e abaixo da junção cemento-esmalte, podendo ser caracterizado como epitélio da bolsa periodontal (Figuras 9 e 10A). Subjacente, ainda nesta região, observou-se discreta exposição de cemento e tecido conjuntivo fibroso do ligamento gengival com intenso infiltrado inflamatório predominantemente PMN e vasos sangüíneos congestos. Observam-se ainda marcante marginação leucocitária e extensão do 
infiltrado inflamatório ao longo do terço cervical da raiz dentária, em proximidade com osso e cemento, bem como em áreas mais profundas e estendendo-se em direção à região de furca e ao dente adjacente. Mais profundamente, notou-se crista óssea alveolar com superfície irregular recoberta por osteoclastos, indicando lacunas de reabsorção nas regiões cervical e média (cerca de 1/3 da altura óssea) (Figuras 9 e 10B).

Na região de furca, observou-se, no tecido conjuntivo fibroso, moderado infiltrado inflamatório PMN e $\mathrm{MN}$ mais superficialmente localizado (1/3 cervical). A crista óssea inter-radicular encontrou-se com superfície freqüentemente recoberta por osteoclastos, revelando extensas lacunas de reabsorção nas porções cervical e média (cerca de 2/3 da altura óssea) (Figura 11).

$\mathrm{Na}$ região interproximal, observou-se maior exuberância de PMNs em proximidade à grande presença de agregados e biofilmes microbianos, bem como ausência do epitélio juncional, compatível com processo destrutivo transoperatório. O ligamento gengival apresentou-se com inúmeros vasos sangüíneos congestos e intenso infiltrado inflamatório predominantemente PMN adjacente ao terço cervical da raiz, além de se estender para a região mesial e de furca do segundo molar adjacente. Profundamente, o ligamento periodontal também se encontrou com moderada inflamação no terço cervical e intensas áreas de reabsorção óssea alveolar nas regiões cervical, média e apical, com a presença de inúmeros osteoclastos.

O envolvimento da região de furca pela inflamação aguda não foi observado em todos os cortes, porém notou-se a extensão do comprometimento periodontal para o segundo molar inferior direito em todos os casos analisados. Ainda, observou-se em um dos casos a presença de restos epiteliais de Malassez na região de furca. 


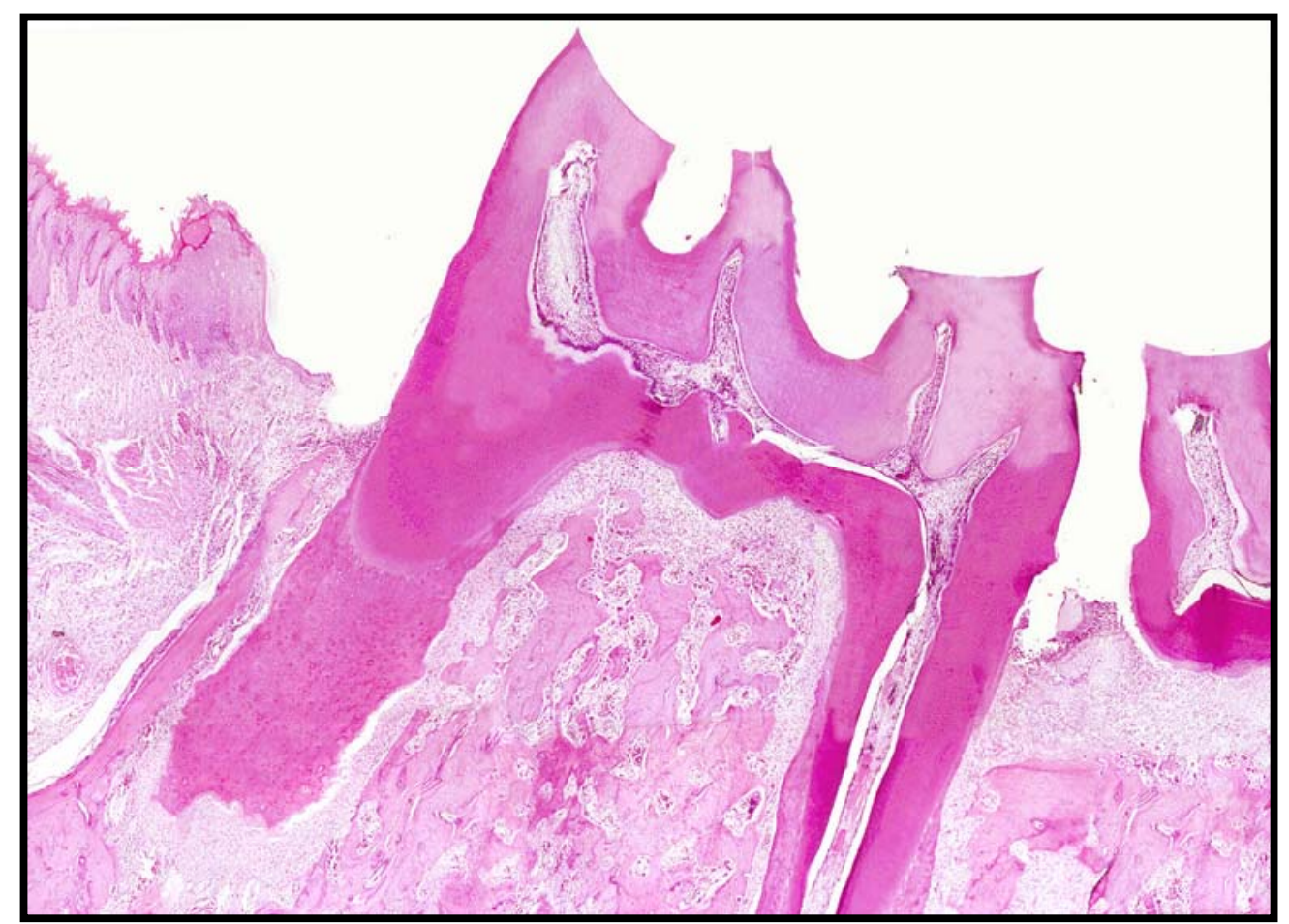

Figura 9: Vista panorâmica de um corte microscópico correspondente ao período de 3 dias de indução da doença periodontal inflamatória por ligadura, ilustrando as relações entre dentes, ligamento periodontal e junção dentogengival (HE; aumento original de $25 x)$.
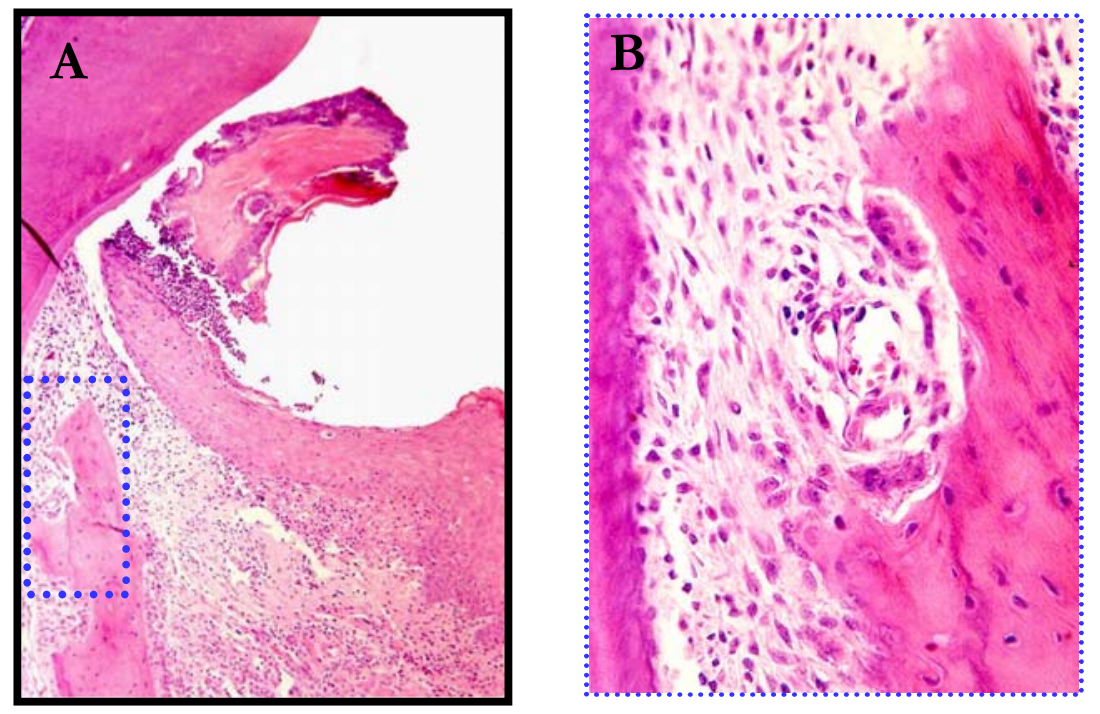

Figura 10: Em A, note a destruição dos epitélios da junção dentogengival na região mesial e a intensa exocitose por PMNs em direção aos agregados e biofilmes microbianos exuberantes. Em B, observe maior aumento da área demarcada em $\mathbf{A}$, correspondente à crista óssea alveolar com superfície irregular recoberta por osteoclastos, indicando lacunas de reabsorção (A e B: H.E.; aumentos originais de 25x e de 100x, respectivamente; 3 dias após a indução experimental). 


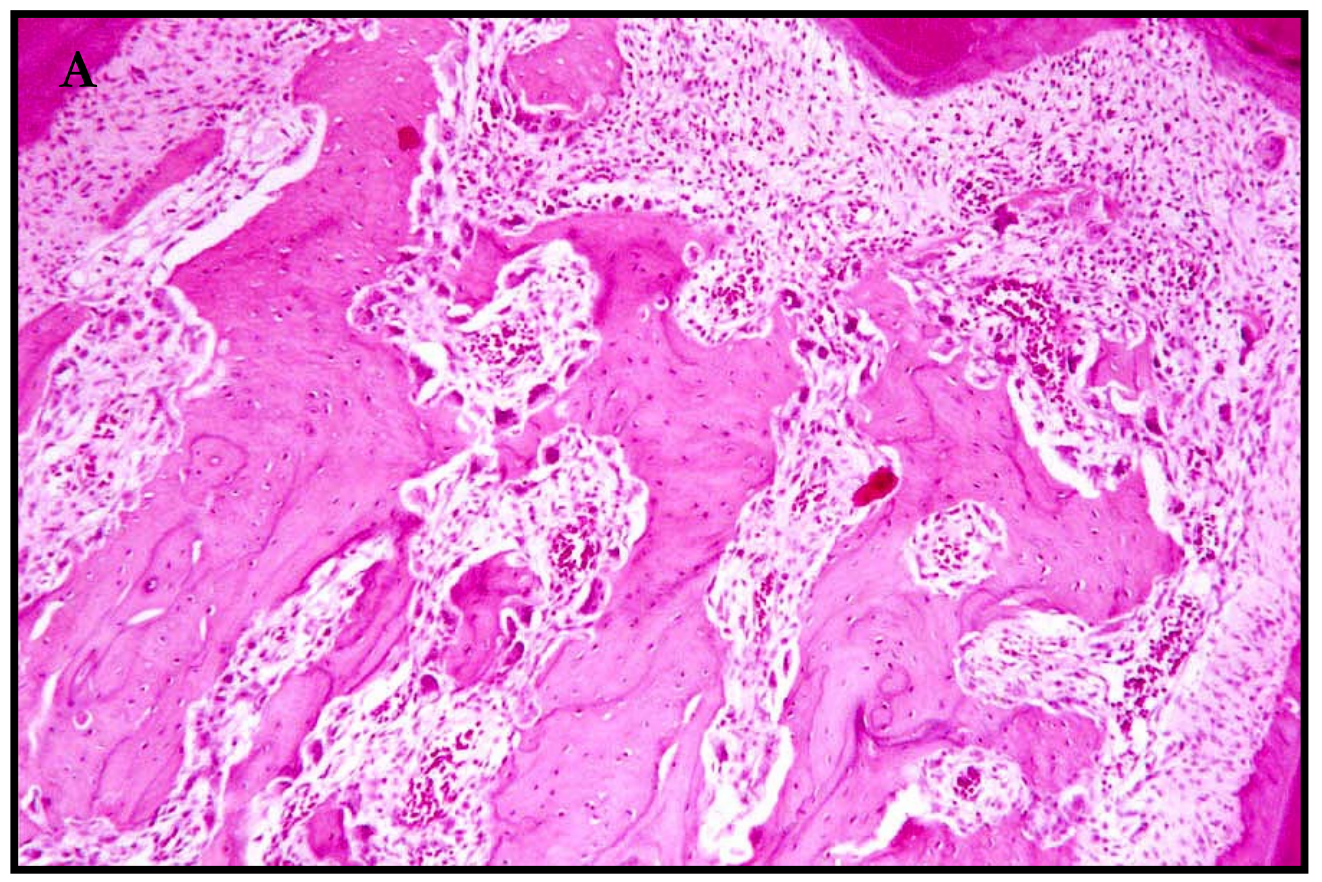

Figura 11: Extensas áreas de reabsorção na superfície da crista óssea alveolar interradicular, bem como moderado infiltrado inflamatório predominantemente PMN (A). Em B, note em detalhe a íntima relação entre as lacunas de reabsorção e os osteoclastos (A e B: HE; aumentos originais de 25x e de 100x, respectivamente; 3 dias após a indução experimental).

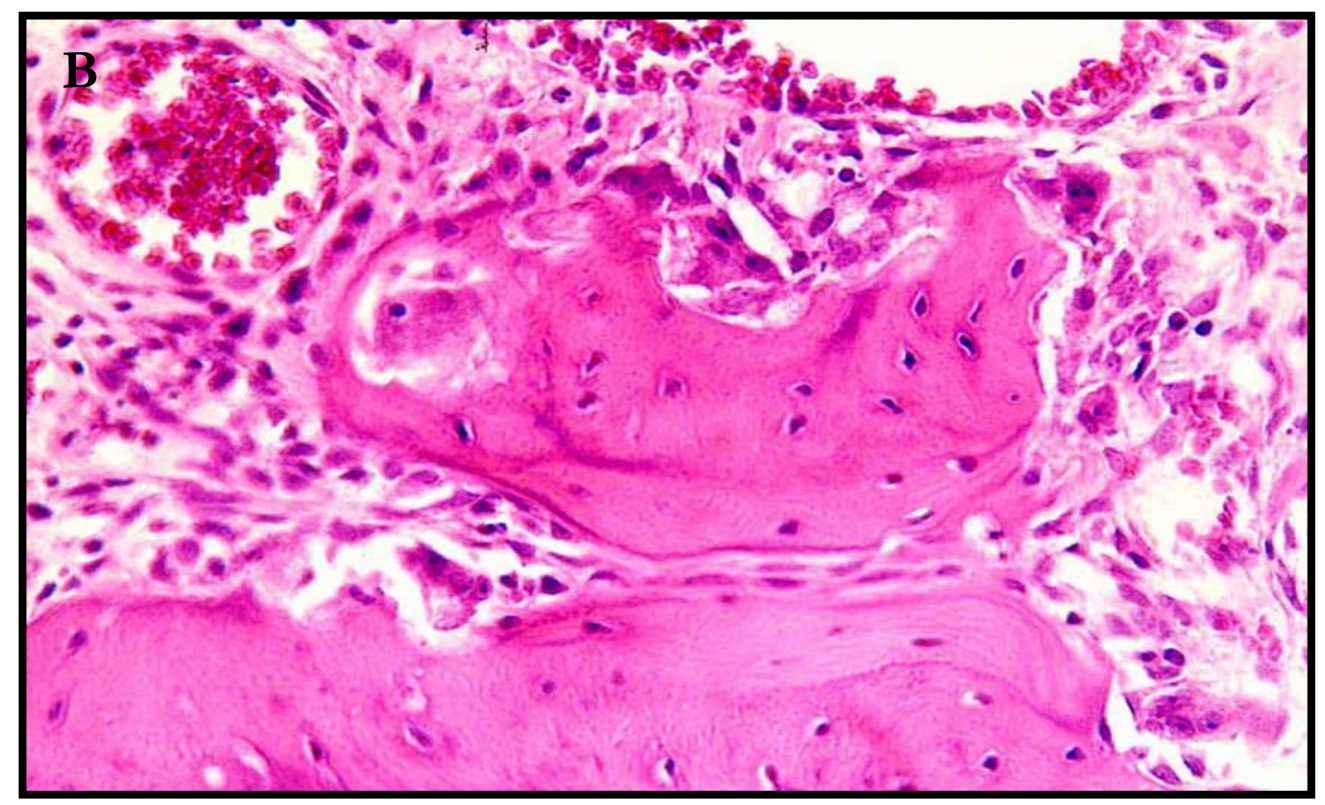


+Período de 7 dias (Esquema 4)

Esquema 4: Representação do primeiro molar inferior direito e de seus tecidos periodontais, após 7 dias da colocação da ligadura (O traçado descontínuo representa virtualmente a superfície do esmalte).

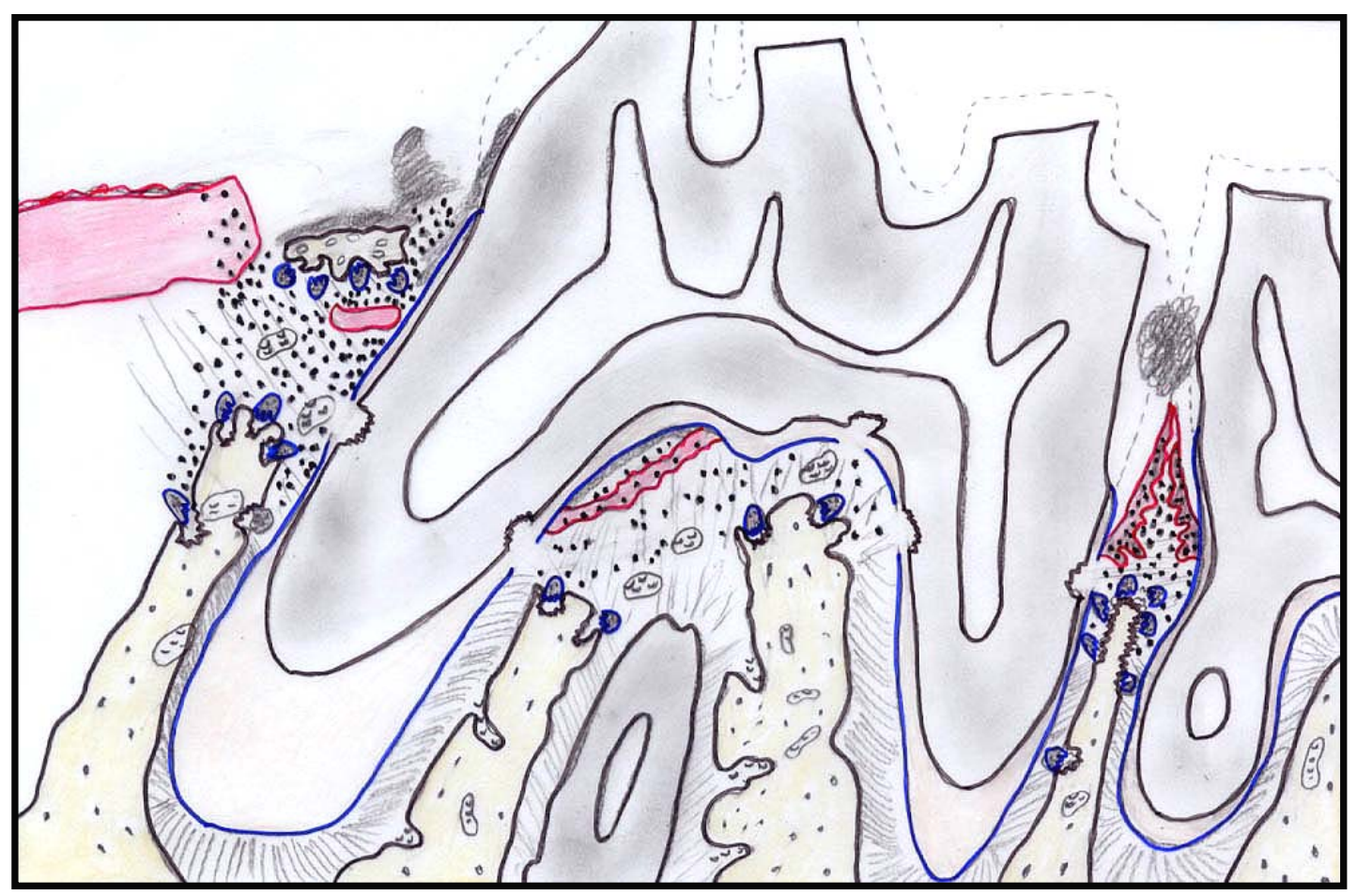

O epitélio de revestimento da mucosa gengival apresentou-se pavimentoso estratificado ora orto ora paraqueratinizado hiperplásico, com exocitose e áreas de necrose superficial, em proximidade a exuberantes agregados e biofilmes microbianos. Na região mesial, o epitélio da bolsa periodontal desorganizado pela inflamação começou a se localizar mais apicalmente, refletindo a situação clínica de presença de bolsa periodontal. Além de migrar para uma posição mais apical, o epitélio da bolsa periodontal encontrou-se hiperplásico e com intensa exocitose por PMNs em direção a agregados e biofilmes microbianos (Figura 12B). Superficialmente, em íntima proximidade com o epitélio desorganizado, notou-se ainda, fragmento de tecido ósseo inviável, com osteoplastos vazios e recoberto por biofilmes microbianos, compatível com seqüestro ósseo (Figura 12A). 
Subjacente, observou-se tecido conjuntivo fibroso com intenso infiltrado inflamatório predominantemente PMN e subepitelial. O infiltrado estendeuse para o terço cervical da raiz dentária, atingindo o ligamento periodontal, bem como em direção mesial. Mais profundamente, notaram-se áreas de reabsorção óssea nas regiões mais superficiais e média da face óssea alveolar, representada pela irregularidade da crista óssea alveolar devido à presença de inúmeros osteoclastos em sua superfície (Figura 12C). A distância entre a junção cemento-esmalte e a crista óssea alveolar pareceu, então, visivelmente aumentada, com extensa exposição da superfície de cemento, o que resulta clinicamente na manutenção da bolsa periodontal.

Na região de furca, também se notou a presença de epitélio da bolsa periodontal, bem como de vasos sangüíneos congestos e discreto infiltrado inflamatório predominantemente $\mathrm{MN}$, com áreas focais de PMNs, estendendo-se pelo terço cervical da raiz dentária. Notaram-se, ainda, eventuais áreas de reabsorção óssea alveolar ao longo da crista óssea.

$\mathrm{Na}$ região interproximal, o epitélio da bolsa periodontal também se encontrava desorganizado pela inflamação e deslocado apicalmente, porém em menor extensão do que na região mesial, com hiperplasia e intensa exocitose por PMNs em direção a agregados e biofilmes microbianos. O intenso infiltrado inflamatório predominantemente PMN estendeu-se para o terço cervical do ligamento periodontal, que se encontrava parcialmente destruído, bem como discretamente para a região mesial do segundo molar adjacente. Mais profundamente, a superfície óssea encontrava-se, em grande parte, recoberta por osteoclastos, evidenciando reabsorção óssea inclusive nas regiões mais profundas, induzindo um leve aumento entre a distância da junção cemento-esmalte e a crista óssea alveolar, com exposição ora discreta ora moderada da superfície cementária.

Observou-se, ainda, a presença de restos epiteliais de Malassez no ápice da raiz mesial em um dos casos, além de áreas de reabsorção 
dentária de superfície irregular ora discretas, nas regiões mesial e interproximal, ora extensas, na região de furca. 


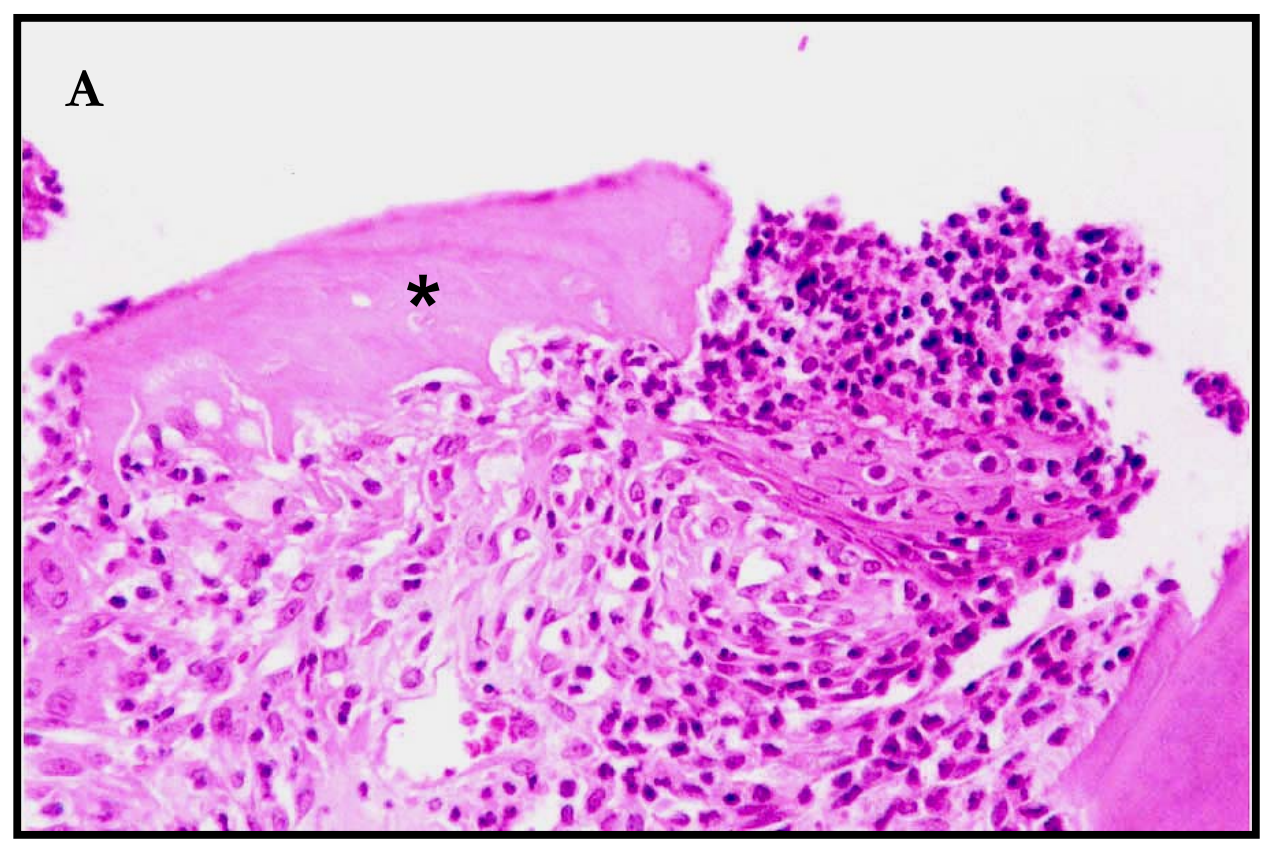

Figura 12: Em A, observa-se seqüestro ósseo $(*)$ envolvido por biofilmes microbianos

em íntima proximidade com o epitélio desorganizado. Em $\mathbf{B}$, note o epitélio da bolsa periodontal hiperplásico e com intensa exocitose por PMNs em direção a agregados e biofilmes microbianos. Em $\mathbf{C}$, note a irregularidade da crista óssea alveolar mesial devido à presença de inúmeros osteoclastos em sua superfície. (A, B e C: HE; aumentos originais de 100x -A e B- e de 25x -C; 7 dias após a indução experimental).
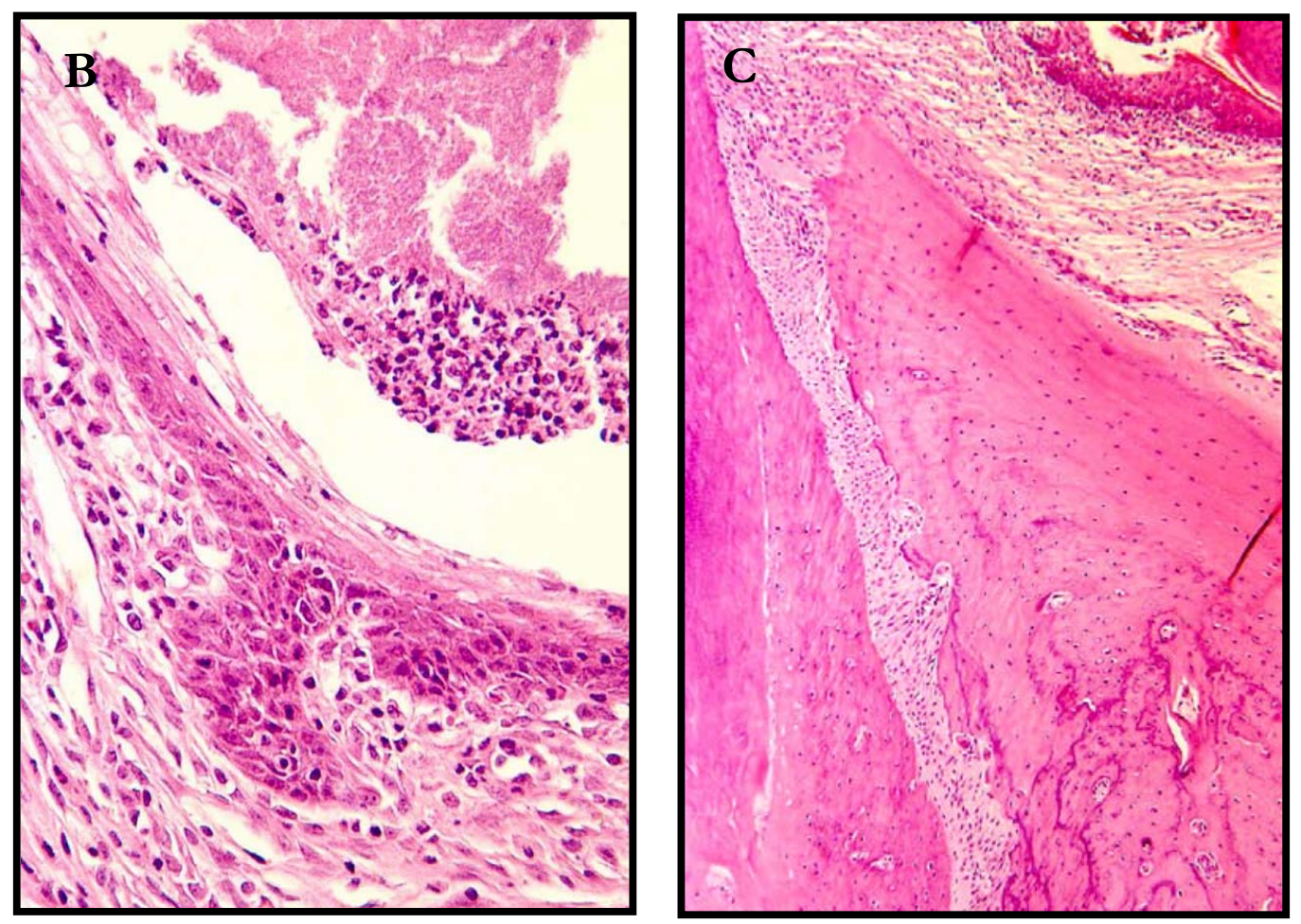


\section{+ Período de 14 dias (Esquema 5)}

Esquema 5: Representação do primeiro molar inferior direito e de seus tecidos periodontais, após 14 dias da colocação da ligadura (O traçado descontínuo representa virtualmente a superfície do esmalte).

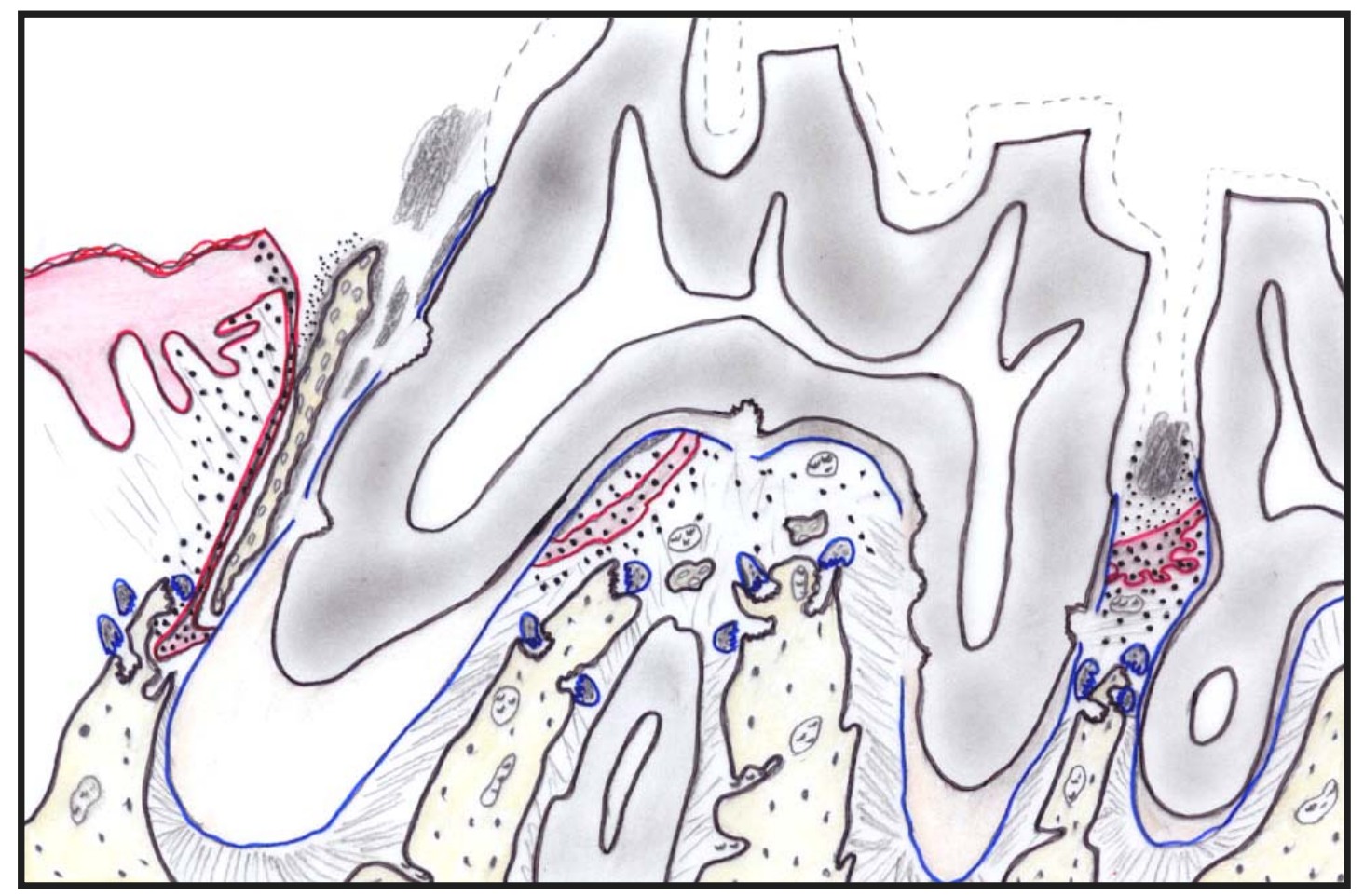

O epitélio de revestimento da mucosa gengival apresentou-se como pavimentoso estratificado ortoqueratinizado hiperplásico, com exocitose por PMNs. Na região mesial, a hiperplasia do epitélio da bolsa periodontal se manteve, assim como seu deslocamento apical e o envolvimento dos agregados e biofilmes microbianos por inúmeros PMNs. Subjacente, observou-se tecido conjuntivo fibroso com moderado infiltrado inflamatório predominantemente PMN, na região logo abaixo do epitélio, além de células MNs difusamente distribuídas. O infiltrado estendeu-se por todo o comprimento da raiz dentária, atingindo o ligamento periodontal de todo o dente. Mais profundamente, notaram-se extensas áreas de reabsorção óssea, culminando com exposição de tecido ósseo inviável, com osteoplastos vazios, recoberto por exuberantes biofilmes microbianos, compatível com 
seqüestro ósseo (Figura 13A). A crista óssea remanescente apresentou-se irregular, devido à presença de inúmeros osteoclastos em sua superfície, evidenciando ainda mais o aumento da distância entre a junção cementoesmalte e a crista óssea alveolar, com extensa exposição da superfície de cemento, recoberta em grande extensão por agregados e biofilmes microbianos, o que resulta clinicamente na manutenção da bolsa periodontal.

$\mathrm{Na}$ região de furca, também se notou migração apical significante do epitélio da bolsa periodontal, com intensa exocitose por PMNs, formando área de abscesso periodontal incipiente. Evidenciou-se ainda a presença de vasos sangüíneos congestos e discreto infiltrado inflamatório predominantemente $\mathrm{MN}$, com áreas focais de intensos PMNs, estendendo-se pelo terço cervical da raiz dentária, além de áreas de reabsorção óssea alveolar.

$\mathrm{Na}$ região interproximal, o epitélio da bolsa periodontal também se encontrava desorganizado pela inflamação, com hiperplasia e intensa exocitose por PMNs em direção a agregados e biofilmes microbianos. O ligamento periodontal apresentou-se parcialmente destruído, com intenso infiltrado inflamatório predominantemente PMN estendendo-se em direção cervical, bem como discretamente para a região mesial do segundo molar adjacente. Profundamente, a superfície óssea encontrava-se recoberta por osteoclastos em praticamente toda sua extensão, aumentando levemente a distância entre a junção cemento-esmalte e a crista óssea alveolar, com exposição ora discreta ora moderada da superfície cementária.

Observou-se, ainda, a presença de restos epiteliais de Malassez especialmente na região de furca do primeiro molar inferior, além de extensas áreas de reabsorção dentária de superfície irregular tanto na região mesial, em seu terço apical e no ápice propriamente dito, porém bem mais evidentes e intensas na região de furca, e discretas na região distal. Notou-se, então, perda de grande parte das estruturas necessárias para o suporte dentário. 


\section{+ Período de 28 dias (Esquema 6)}

Esquema 6: Representação do primeiro molar inferior direito e de seus tecidos periodontais, após 28 dias da colocação da ligadura (O traçado descontínuo representa virtualmente a superfície do esmalte).

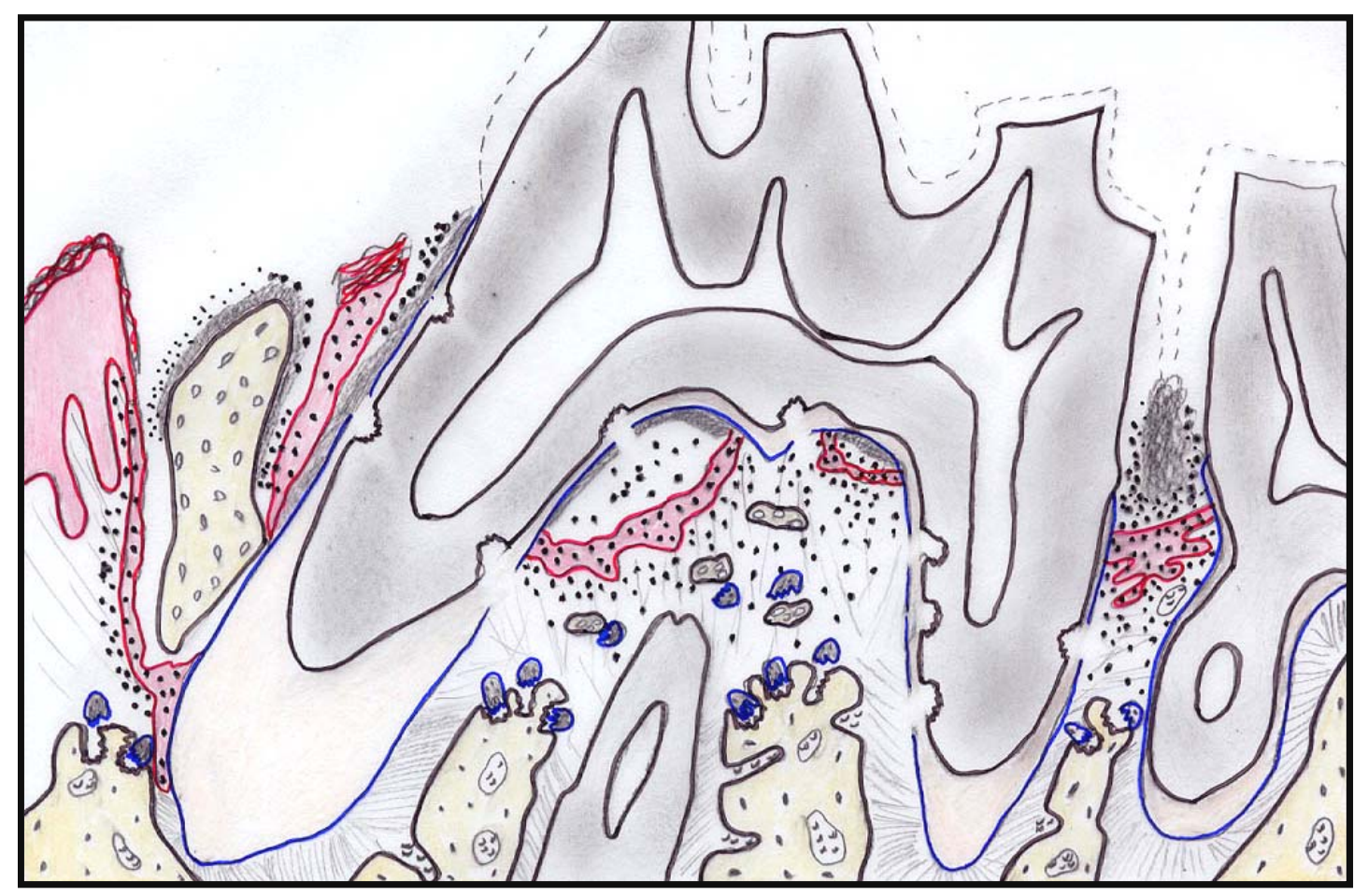

Neste período, observou-se destruição, marcada por áreas de necrose superficial, dos epitélios gengival e da bolsa periodontal na região mesial do primeiro molar inferior. Nas áreas onde foi possível se identificar o epitélio, este se encontrou com extensa migração apical, recobrindo somente o terço apical da raiz dentária, além de hiperplasia e intensa exocitose por PMNs. Superficialmente, notou-se tecido ósseo inviável, com osteoplastos vazios e superfície recoberta por exuberantes biofilmes microbianos e PMNs neutrófilos, compatível com osteomielite e formação de seqüestros ósseos (Figura 13B). No tecido conjuntivo subjacente, observou-se discreto infiltrado inflamatório predominantemente MN superficial, bem como PMNs na região subepitelial. 
Na região de furca, também se observou a presença de epitélio da bolsa periodontal com intensa exocitose por PMNs e intenso infiltrado inflamatório neutrofílico focal, resultando na formação tanto de exsudato purulento quanto de áreas de abscesso periodontal e reabsorção óssea.

Na região interproximal, notou-se acentuação do deslocamento apical do epitélio da bolsa periodontal, que se encontrava hiperplásico e com exocitose por PMNs, em direção a agregados e biofilmes microbianos. O intenso infiltrado inflamatório PMN atingiu, mais evidentemente, o periodonto de sustentação, causando destruição parcial do ligamento periodontal e reabsorção da crista óssea alveolar.

A partir deste período, o nível de perda óssea foi tão grande que chegou a comprometer a sustentação do $1^{\circ}$ molar inferior, praticamente ausente na região mesial, acompanhado por marcante exposição de cemento.

Observou-se, ainda, a presença de escassos restos epiteliais de Malassez na região de furca do primeiro molar inferior, além de extensas áreas de reabsorção dentária de superfície irregular tanto nas regiões mesial e, mais evidentemente, na região de furca. 


\section{+ Período de 42 dias (Esquema 7)}

Esquema 7: Representação do primeiro molar inferior direito e de seus tecidos periodontais, após 42 dias da colocação da ligadura ( $\mathrm{O}$ traçado descontínuo representa virtualmente a superfície do esmalte).

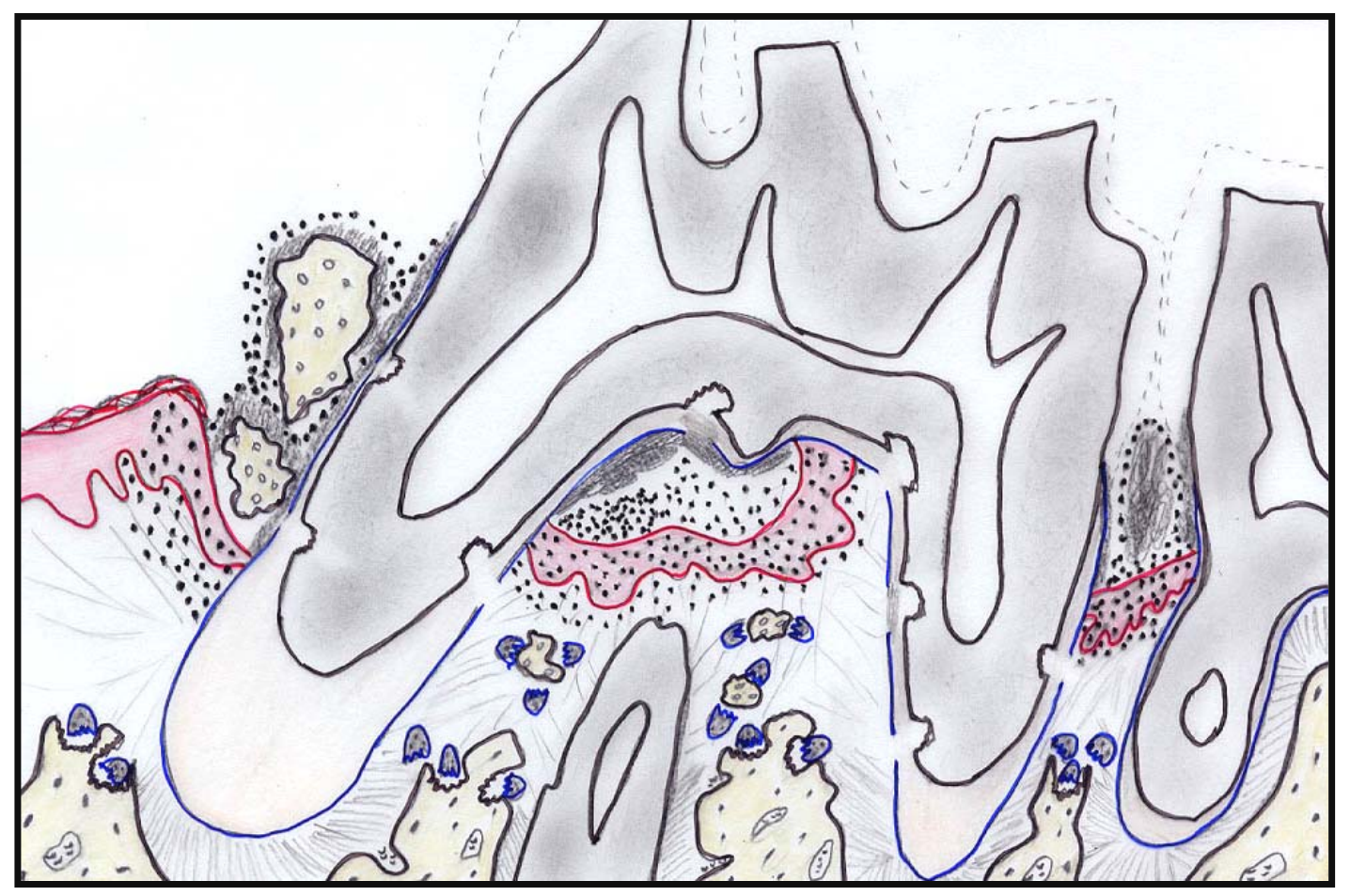

Os epitélios da mucosa gengival e da bolsa periodontal encontravam-se ulcerados e com intensa exocitose por PMNs. O epitélio da bolsa manteve sua extensa migração apical e a raiz mesial encontrava-se recoberta em toda sua extensão por agregados e biofilmes microbianos. Superficialmente, também se observou a presença de tecido ósseo inviável, com osteoplastos vazios e superfície recoberta por biofilmes microbianos e PMNs, compatível com osteomielite e formação de seqüestros ósseos. No tecido conjuntivo subjacente, observou-se moderado infiltrado inflamatório predominantemente MN superficial, bem como PMNs na região subepitelial.

Na região de furca, a migração apical do epitélio da bolsa periodontal foi muito mais extensa que aos 28 dias. Observou-se, nesta área, 
presença de epitélio pavimentoso estratificado hiperplásico com intensa exocitose por PMNs em direção a exuberantes biofilmes microbianos aderidos à superfície radicular. Adjacente a estes, observou-se extensa área de abscesso periodontal (Figura 13D). Notou-se, ainda, intenso infiltrado inflamatório predominantemente $\mathrm{MN}$, mais profundamente no tecido conjuntivo, além de fragmentos de tecido ósseo envolvidos por células gigantes multinucleadas compatíveis com osteoclastos, caracterizando seqüestros ósseos.

Na região interproximal, a migração apical do epitélio da bolsa periodontal também foi mais extensa do que aos 28 dias, observando-se hiperplasia e exocitose, além de subjacente moderado infiltrado inflamatório predominantemente MN e subepitelial. Observou-se, também, extensa reabsorção óssea e exposição de cemento.

Notaram-se, ainda, na região de furca, a presença de eventuais corpúsculos eosinofílicos arredondados em íntima proximidade com o cemento, compatível com cementículos, bem como áreas de reabsorção óssea e presença de seqüestros ósseos.

Observou-se reabsorção dentária, ora de superfície irregular ora paralisada, envolvendo as regiões mesial, de furca e interproximal. 


\section{+ Período de 56 dias (Esquema 8)}

Esquema 8: Representação do primeiro molar inferior direito e de seus tecidos periodontais, após 56 dias da colocação da ligadura ( $\mathrm{O}$ traçado descontínuo representa virtualmente a superfície do esmalte).

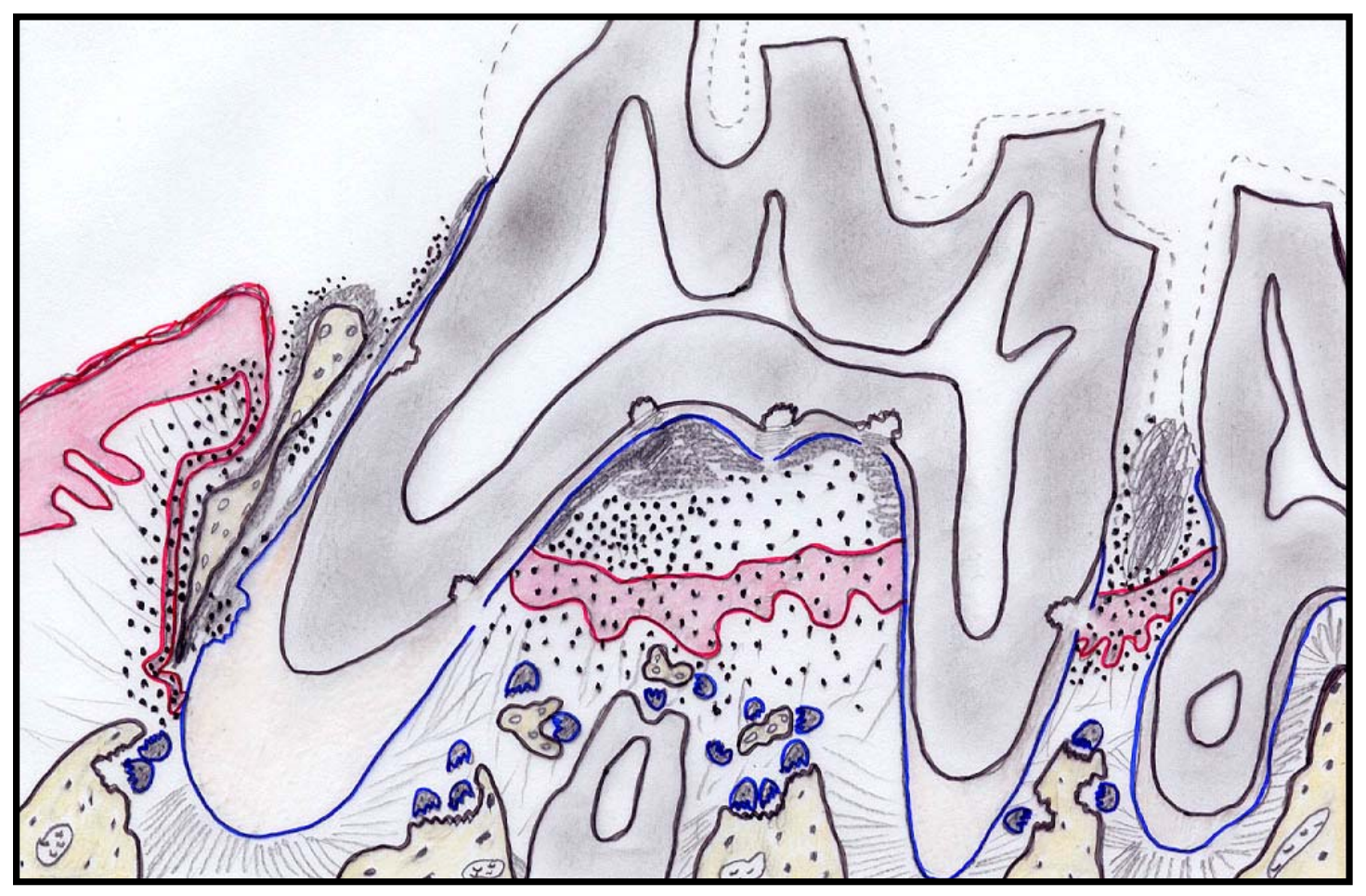

Na região mesial, o epitélio da bolsa periodontal manteve-se hiperplásico e com moderada exocitose por PMNs em direção a grande quantidade de agregados e biofilmes microbianos, porém notou-se menor grau de inflamação no tecido conjuntivo subjacente. Este quadro representa, portanto, uma evolução daquele que já se observava no período de 42 dias. Notou-se, ainda, a presença de tecido ósseo inviável, com osteoplastos vazios e superfície recoberta por biofilmes microbianos e PMNs, compatível com osteomielite e formação de seqüestros ósseos. Profundamente, a crista óssea alveolar encontrava-se praticamente ausente (Figura 13C).

Na região de furca, a migração apical do epitélio da bolsa periodontal foi ainda mais extensa que aos 42 dias. Observou-se, nesta área, 
epitélio pavimentoso estratificado hiperplásico com intensa exocitose por PMNs em direção a biofilmes microbianos aderidos à superfície radicular, estendendo ainda mais a área de abscesso periodontal. Mais profundamente, no tecido conjuntivo, notou-se intenso infiltrado inflamatório ora $\mathrm{MN}$ ora PMN, principalmente subepitelial, além de fragmentos de tecido ósseo envolvidos por células gigantes multinucleadas compatíveis com osteoclastos, caracterizando seqüestros ósseos. A superfície da crista óssea inter-radicular encontrava-se irregular, com inúmeros osteoclastos em sua superfície, caracterizando reabsorção óssea do tipo vertical.

Na região interproximal, a migração apical do epitélio da bolsa periodontal também foi mais extensa do que aos 42 dias, observando-se hiperplasia e exocitose por PMNs, além de moderado infiltrado inflamatório predominantemente $\mathrm{MN}$ e subepitelial, e reabsorção da crista óssea alveolar distal. Notaram-se, ainda, áreas de reabsorção dentinária paralisada, especialmente na região de furca. 


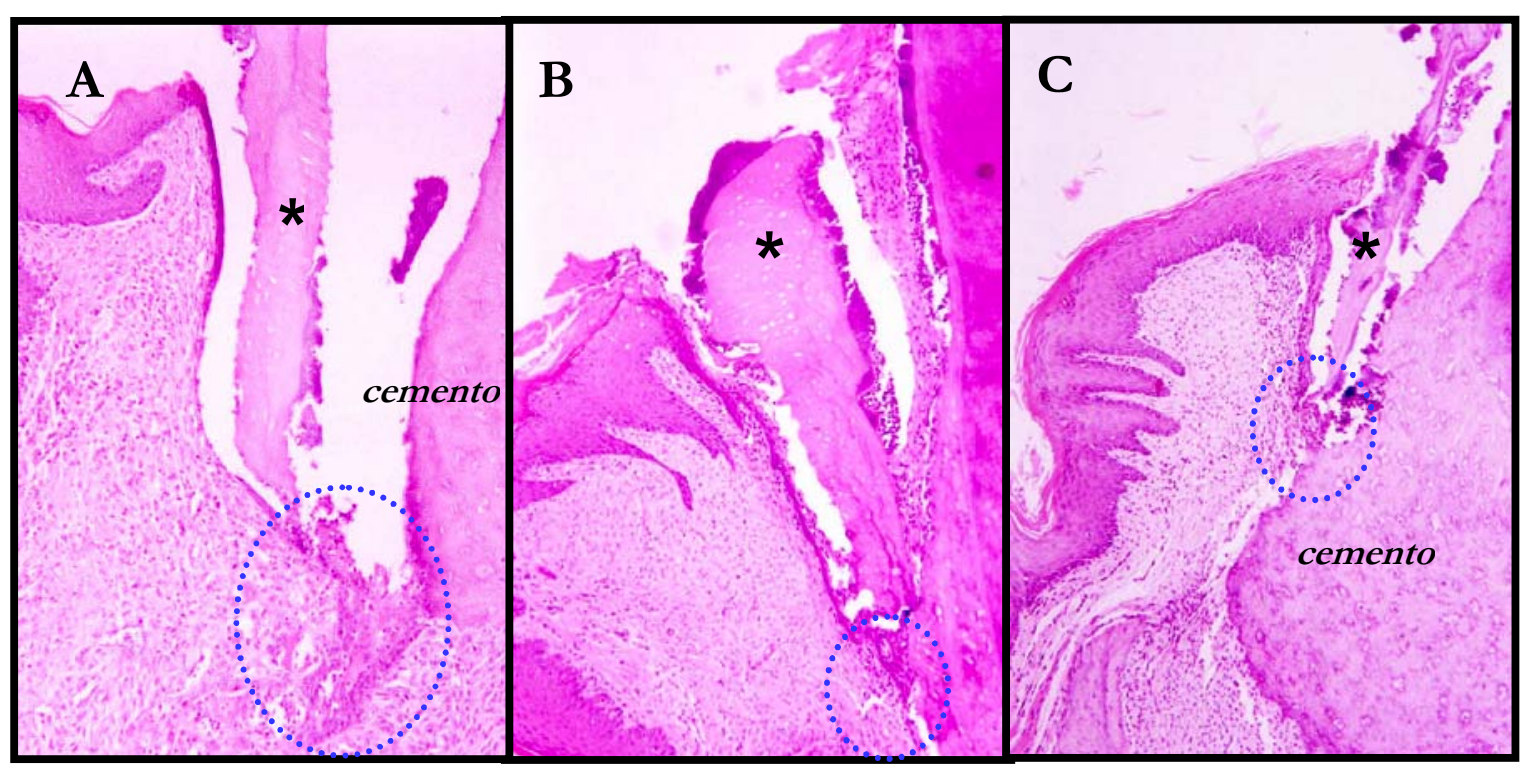

Figura 13: Note as áreas destacadas correspondentes à extensão apical do epitélio juncional (bolsa periodontal) associada à presença de seqüestros ósseos (*) cada vez maiores em todos os períodos seguintes $(\mathbf{A}=14$ dias, $\mathbf{B}=28$ dias e $\mathbf{C}=56$ dias após a indução experimental). Em $\mathbf{D}$, observa-se evolução para abscesso periodontal na região de furca do primeiro molar inferior direito após 42 dias de indução experimental (A, B e C: HE; aumentos originais de 25x e D: HE; aumento original de 100x).

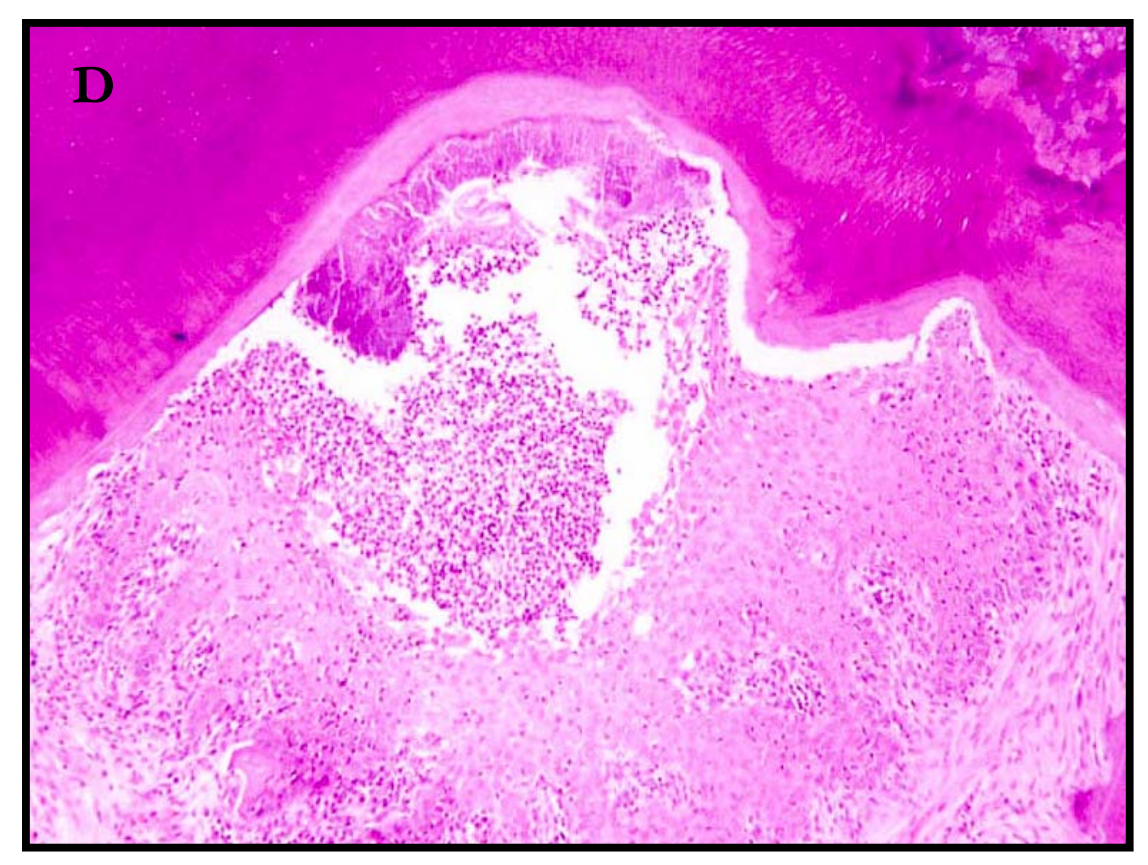




\section{3-Análise microscópica morfológica das amostras de tecido gengival}

\subsection{1- Tecidos periodontais normais}

Considerando as amostras controle vestibular e lingual, os cortes microscópicos revelaram mucosa gengival constituída por epitélio pavimentoso estratificado ortoqueratinizado, predominantemente sem cristas. Em continuidade, em íntima relação com a superfície dentária, observou-se epitélio pavimentoso estratificado ora orto ora paraqueratinizado, sem cristas, compatível com epitélio sulcular, bem como delgado epitélio composto por uma a três camadas de células achatadas, não queratinizado, sem cristas, compatível com epitélio juncional, com discreta exocitose por PMNs. Subjacente a este epitélio, notou-se tecido conjuntivo fibroso frouxamente arranjado, com inúmeros vasos sangüíneos e escassas células MN e PMNs perivasculares e subepiteliais.

Em continuidade com a junção dentogengival, em direção mesial, notou-se mucosa bucal constituída por epitélio pavimentoso estratificado ortoqueratinizado apresentando largas cristas. O tecido epitelial, incluindo a camada de queratina, apresentou-se mais espesso quando comparado à junção dentogengival (Figura 14A). Subjacente à mucosa bucal, observou-se tecido conjuntivo fibroso com escassas células inflamatórias MNs, predominantemente perivasculares e subepiteliais e, logo abaixo, tecido muscular, bem como feixes vasculonervosos. Notaram-se, ainda, mastócitos perivasculares e perineurais. Em alguns cortes, observaram-se fragmentos de cemento perifericamente.

Na região lingual, tanto do 1o quanto do 2o molar, o epitélio da mucosa bucal apresentou cristas epiteliais mais longas e, nos planos mais profundos, inúmeras glândulas salivares menores. 


\subsection{2- Tecidos periodontais submetidos ao progressivo acúmulo de placa dentobacteriana por meio da colocação de ligadura}

As referidas amostras estão descritas abaixo de acordo com os diferentes períodos de indução experimental da doença periodontal inflamatória por meio da colocação da ligadura.

\section{+ Período de 1 dia}

$\mathrm{Na}$ região lingual, os cortes microscópicos revelaram integridade da arquitetura tecidual, porém alterações inflamatórias na junção dentogengival e no tecido conjuntivo subjacente. Observou-se mucosa gengival constituída por epitélio pavimentoso estratificado ortoqueratinizado hiperplásico e com cristas. Em continuidade, observaramse os epitélios sulcular e juncional, este progressivamente hiperplásico e com exocitose por PMNs. Subjacente a este, o tecido conjuntivo fibroso encontrouse com vasos sangüíneos congestos apresentando marginação leucocitária e com infiltrado inflamatório moderado a intenso constituído por células MN e PMNs.

Em continuidade com a junção dentogengival, notou-se mucosa bucal constituída por epitélio pavimentoso estratificado ortoqueratinizado, com largas cristas. Subjacente, observou-se tecido conjuntivo fibroso com infiltrado inflamatório ora $\mathrm{MN}$ ora $\mathrm{PMN}$, incluindo eosinófilos, variando de moderado a intenso, difusamente distribuído.

Na região vestibular, não foi possível a distinção microscópica dos epitélios da junção dentogengival, que se apresentavam com áreas de destruição recobertas por agregados e biofilmes microbianos. O tecido conjuntivo fibroso subjacente apresentou inúmeros vasos sangüíneos congestos com marginação leucocitária, além de infiltrado inflamatório, ora 
moderado ora intenso, com inúmeros PMNs perivasculares e subepiteliais, bem como MNs difusamente distribuídos.

Em continuidade com a junção dentogengival, notou-se mucosa bucal constituída por epitélio pavimentoso estratificado ortoqueratinizado, com largas cristas. Subjacente, observou-se tecido conjuntivo fibroso com infiltrado inflamatório difuso, tanto PMN quanto $\mathrm{MN}$, destacando-se a presença de mastócitos em íntima proximidade a células MNs com morfologia de linfócitos.

Observou-se, ainda, tanto na região lingual quanto vestibular, a presença de infiltrado inflamatório $\mathrm{MN}$ e PMN, incluindo eosinófilos, de permeio a feixes de fibras musculares esqueléticas localizados logo abaixo e mais profundamente, bem como de permeio a filetes nervosos.

\section{+ Período de 3 dias}

$\mathrm{Na}$ região lingual, os cortes microscópicos mantiveram a integridade da arquitetura tecidual, porém as alterações inflamatórias na junção dentogengival e no tecido conjuntivo subjacente foram acentuadas. Observou-se mucosa gengival constituída por epitélio pavimentoso estratificado ortoqueratinizado hiperplásico e com cristas, em continuidade com os epitélios sulcular e juncional, este progressivamente hiperplásico, com exocitose por PMNs e deslocado apicalmente, próximo aos tecidos muscular e glandular, compatível com epitélio juncional longo. Subjacente a este, o tecido conjuntivo fibroso encontrou-se com inúmeros vasos sangüíneos congestos, marginação leucocitária e moderada à intensa infiltração por células MN e PMNs.

Em continuidade com a junção dentogengival, notou-se mucosa bucal constituída por epitélio pavimentoso estratificado ortoqueratinizado com cristas. Subjacente, observou-se tecido conjuntivo fibroso com infiltrado 
inflamatório ora MN ora PMN, incluindo eosinófilos, variando de moderado a intenso, difusa e profundamente distribuído.

Na região vestibular, também não foi possível a distinção microscópica entre os epitélios da junção dentogengival, que se apresentavam com intensa exocitose por PMNs em direção a agregados e biofilmes microbianos, bem como com áreas de destruição. $O$ tecido conjuntivo fibroso subjacente apresentou inúmeros vasos sangüíneos congestos com marginação leucocitária, áreas de derramamento de fibrina, além de infiltrado inflamatório, ora moderado ora intenso, difusamente distribuído.

Em continuidade com a junção dentogengival, notou-se mucosa bucal constituída por epitélio pavimentoso estratificado ortoqueratinizado com cristas. Subjacente, observou-se tecido conjuntivo fibroso com infiltrado inflamatório difuso, tanto PMN quanto MN, destacando-se a desorganização e a destruição do tecido muscular profundamente.

\section{+ Período de 7 dias}

$\mathrm{Na}$ região lingual, as características microscópicas foram semelhantes àquelas do período anterior, sem aumento aparente da inflamação, porém com maior extensão apical do epitélio juncional.

$\mathrm{Na}$ região vestibular, os epitélios da junção dentogengival também se mantiveram destruídos e recobertos por biofilmes microbianos circundados por PMNs. O tecido conjuntivo fibroso subjacente à junção dentogengival apresentou-se intensamente vascularizado e com intenso infiltrado inflamatório difusamente distribuído, predominantemente $\mathrm{MN}$, compatível com tecido de granulação (Figura 14B), além de eventuais PMNs 
especialmente intra e perivasculares, bem como subepiteliais, em direção aos biofilmes microbianos na superfície.

Em continuidade com a junção dentogengival, notou-se mucosa bucal constituída por epitélio pavimentoso estratificado ortoqueratinizado, com cristas. Subjacente, observou-se tecido conjuntivo fibroso com intenso infiltrado inflamatório $\mathrm{MN}$ e PMN, especialmente próximo ao epitélio, porém estendendo-se profundamente de permeio a feixes de fibras musculares esqueléticas. Tais fibras musculares apresentavam-se irregularmente dispostas e morfologicamente alteradas, consistindo-se de células com núcleo picnótico e às vezes multinucleadas, compatível com alteração patológica regressiva semelhante à encontrada em casos de miosite 34 .

\section{+ Período de 14 dias}

Na região lingual, as características microscópicas também se mantiveram, sem aumento aparente da inflamação.

$\mathrm{Na}$ região vestibular, os componentes epiteliais da junção dentogengival estavam desorganizados, com áreas de ulceração e necrose superficial, e recobertos por exsudato serofibrinoso e extensos agregados e biofilmes microbianos. Subjacente, o tecido conjuntivo apresentou moderado a intenso infiltrado inflamatório difusamente distribuído, predominantemente $\mathrm{MN}$, com eventuais PMNs especialmente intra e perivasculares, bem como subepiteliais (Figura 14C).

Em continuidade com a junção dentogengival, notou-se mucosa bucal constituída por epitélio pavimentoso estratificado ortoqueratinizado, com cristas. Subjacente, observou-se tecido conjuntivo fibroso com infiltrado inflamatório ora moderado ora intenso e predominantemente $\mathrm{MN}$, com eventuais PMNs especialmente intra e perivasculares, bem como áreas 
sugestivas de fibrose tecidual. O infiltrado inflamatório parece, então, estar mais localizado e superficial.

+ Período de 30 dias

Os achados microscópicos sugerem aparente regressão da inflamação, tanto na região lingual quanto vestibular.

Com relação à região vestibular, em contraste com os períodos anteriores, os componentes epiteliais da junção dentogengival estavam íntegros e com aspecto de normalidade, com as características microscópicas semelhantes àquelas observadas nas amostras controle. Subjacente, o tecido conjuntivo fibroso apresentou-se com discreto infiltrado inflamatório $\mathrm{MN}$ predominantemente subepitelial e perivascular.

Em continuidade com a junção dentogengival, notou-se mucosa bucal constituída por epitélio pavimentoso estratificado ortoqueratinizado, com cristas. Subjacente, observou-se tecido conjuntivo fibroso com áreas de fibrose e discreto infiltrado inflamatório predominantemente MN. 


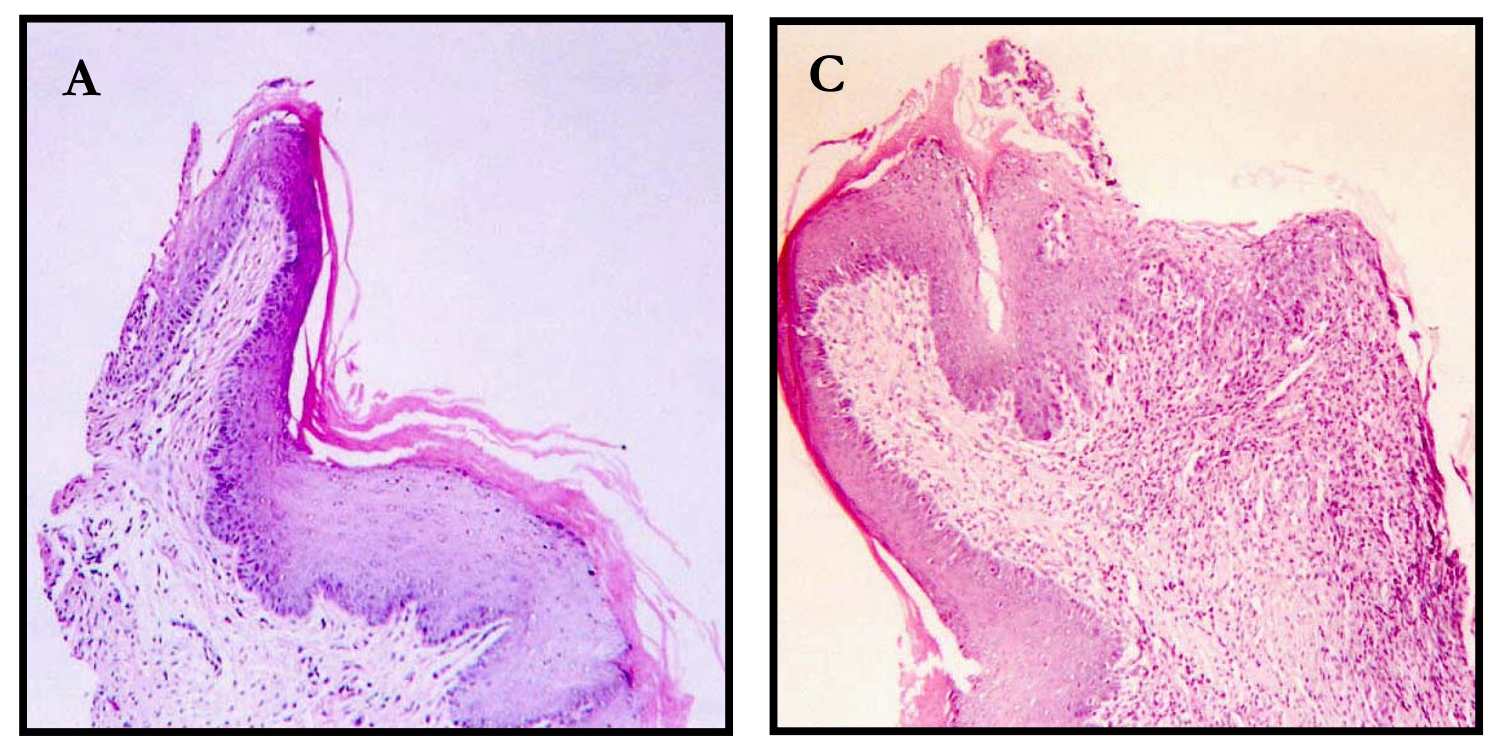

Figura 14: Em A, observe a amostra gengival do lado controle utilizada para a análise morfológica, com destaque à junção dentogengival. Em B, corte microscópico da amostra gengival com doença periodontal inflamatória induzida por 7 dias, revelando tecido conjuntivo fibroso subjacente à junção dentogengival com intensa vascularização e infiltrado inflamatório difusamente distribuído, predominantemente $\mathrm{MN}$, compatível com tecido de granulação, além de eventuais PMNs. Em C, observe a amostra gengival com desorganização dos componentes epiteliais da junção dentogengival, agregados e biofilmes microbianos e, subjacente, tecido conjuntivo fibroso com infiltrado inflamatório difusamente distribuído, ora moderado ora intenso, predominantemente $\mathrm{MN}$, correspondente ao período de 14 dias após a indução experimental (A, B e $\mathbf{C}$ : HE; aumentos originais de 25x -A e $\mathbf{C}$ e de 100x -B).

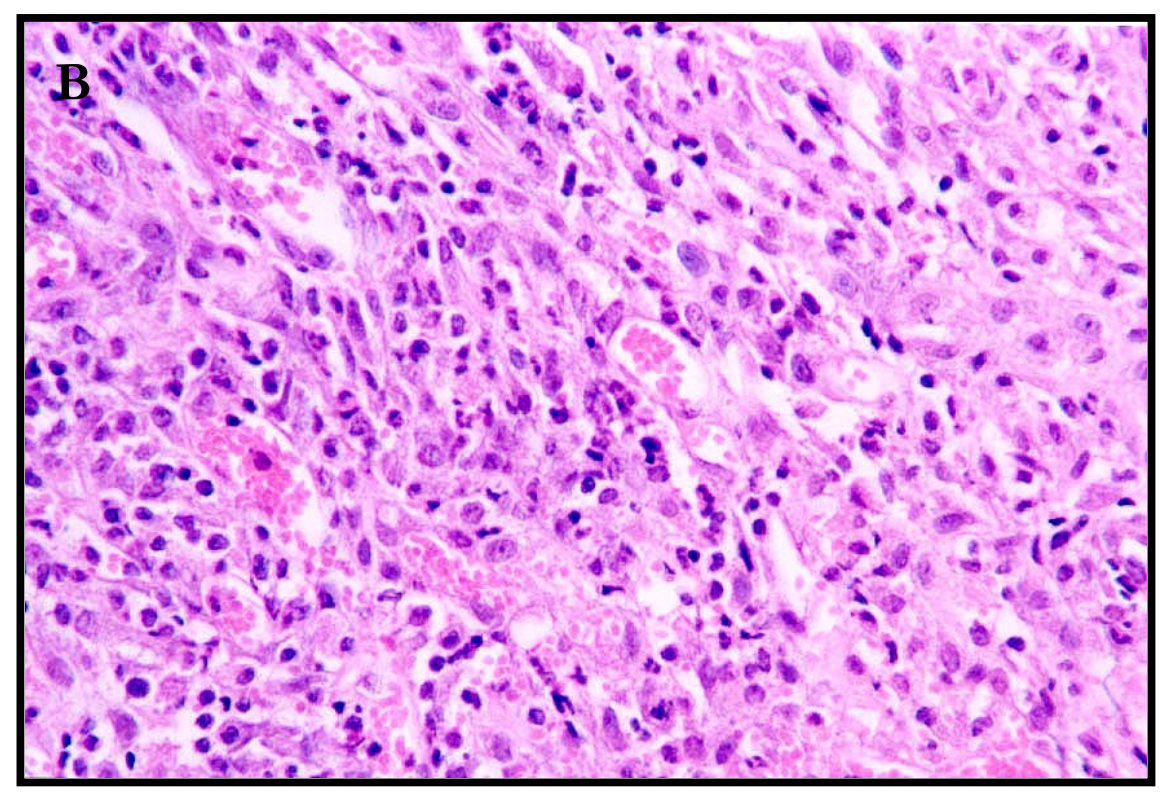




\section{4- Análise quantitativa dos mastócitos}

Os mastócitos evidenciados pela coloração de AT nas amostras gengivais apresentaram seus grânulos citoplasmáticos com coloração púrpura, ora densa ora discreta, bem como morfologias variadas, desde células pequenas e arredondadas/fusiformes até células grandes e ovaladas. Observaram-se, ainda, freqüentes áreas difusamente coradas. A contagem dos mastócitos resultou em número destas células por $\mathrm{mm}^{2}$, nas diferentes regiões (1, 2 e 3; lados vestibular e lingual), ao longo dos períodos de indução da doença periodontal inflamatória, dos lados controle e doente.

Primeiramente, a avaliação estatística do erro casual interexaminadores revelou valores altos (Tabela C). Então, optou-se pela utilização dos valores médios entre os 3 examinadores em todos os testes estatísticos. 
Tabela C: Erro inter-examinadores, calculado dois a dois, para cada região (1, 2 e 3; lados vestibular e lingual) das amostras gengivais controle e doente, independente do período de indução da doença periodontal inflamatória por ligadura. Os valores do erro estão representados pelo número de mastócitos $/ \mathrm{mm}^{2}$, observados por meio da coloração de AT.

\begin{tabular}{|c|c|c|c|}
\hline Região Comparação & $\mathrm{C} \times \mathrm{A}$ & $\mathrm{C} \times \mathrm{P}$ & $A \times P$ \\
\hline$\overline{\mathrm{DP}-\mathrm{V} 1}$ & 9,62 & 9,12 & 6,49 \\
\hline DP-V2 & 14,79 & 12,78 & 13,80 \\
\hline DP-V3 & 12,05 & 10,83 & 6,92 \\
\hline$\overline{\text { DP-L1 }}$ & 6,50 & 5,31 & 8,58 \\
\hline DP-L2 & 8,55 & 6,37 & 7,32 \\
\hline DP-L3 & 12,49 & 12,20 & 9,58 \\
\hline C-V1 & 7,82 & 13,93 & 9,29 \\
\hline C-V2 & 19,16 & 6,35 & 18,68 \\
\hline $\mathrm{C}-\mathrm{V} 3$ & 13,13 & 10,40 & 9,16 \\
\hline$\overline{C-L 1}$ & 23,79 & 7,64 & 28,27 \\
\hline C-L2 & 25,54 & 2,94 & 25,71 \\
\hline C-L3 & 7,49 & 10,86 & 10,53 \\
\hline
\end{tabular}

Legenda:

C, A e P (Comparação) = examinadores

$\mathrm{C}($ Região $)=$ lado controle

1, 2 e 3 = regiões utilizadas para análise em AT

$\mathrm{DP}=$ lado com doença periodontal induzida

$\mathrm{V}=$ lado vestibular

$\mathrm{L}=$ lado lingual

Os valores médios do número de mastócitos $/ \mathrm{mm}^{2}$ foram, então, utilizados para uma comparação entre as 3 regiões (1, 2 e 3) avaliadas em AT, por cada período de indução experimental da doença periodontal inflamatória (1, 3, 7, 14 e 30 dias). Entretanto, dado o pequeno número da amostra, a grande variabilidade observada entre os valores médios ao longo do tempo, bem como o elevado desvio-padrão e a eventual perda de parte do 
tecido a ser analisado, a validade desta análise descritiva por período foi questionável (Quadros 1 e 2; Figuras 15, 16 e 17). Portanto, optou-se pela realização de uma comparação geral entre controle e doença periodontal inflamatória, utilizando-se as médias dos valores obtidos para cada região (1, 2 e 3; lados vestibular e lingual) independente do período de indução da doença, seguida pelo teste não paramétrico de Wilcoxon. A partir deste teste, observou-se diferença estatisticamente significativa entre os tecidos controle e doente somente com relação à região 1, tanto do lado vestibular quanto lingual, observando-se maior quantidade de mastócitos $/ \mathrm{mm}^{2}$ nas amostras gengivais controle (Quadro 3). 
Quadro 1: Valores médios do número de mastócitos $/ \mathrm{mm}^{2} \pm$ desvios-padrão (dp) utilizados na comparação entre as 3 regiões (1, 2 e 3 ) avaliadas em AT, por cada período de indução experimental da doença periodontal inflamatória $(1,3,7,14$ e 30 dias), para o lado doente das amostras gengivais.

\begin{tabular}{|c|c|c|c|}
\hline Região & Valores Médios $\pm d p$ & Período [dia (s)] & $n$ \\
\hline \multirow{5}{*}{ DP-V1 } & $6,64 \pm 7,81$ & 1 & 3 \\
\hline & $12,42 \pm 9,17$ & 3 & 3 \\
\hline & $0,29 \pm 0,86$ & 7 & 3 \\
\hline & $10,97 \pm 13,44$ & 14 & 3 \\
\hline & $15,60 \pm 13,35$ & 30 & 3 \\
\hline \multirow{5}{*}{ DP-V2 } & $16,76 \pm 12,55$ & 1 & 3 \\
\hline & $19,07 \pm 11,73$ & 3 & 3 \\
\hline & $24,85 \pm 29,63$ & 7 & 3 \\
\hline & $45,95 \pm 34,64$ & 14 & 3 \\
\hline & $53,18 \pm 23,14$ & 30 & 3 \\
\hline \multirow{5}{*}{ DP-V3 } & $7,51 \pm 11,37$ & 1 & 3 \\
\hline & $4,62 \pm 6,06$ & 3 & 3 \\
\hline & $11,55 \pm 8,55$ & 7 & 3 \\
\hline & $14,45 \pm 15,11$ & 14 & 3 \\
\hline & $5,78 \pm 8,80$ & 30 & 3 \\
\hline \multirow{5}{*}{ DP-L1 } & $10,40 \pm 11,92$ & 1 & 3 \\
\hline & $4,62 \pm 3,70$ & 3 & 3 \\
\hline & $3,47 \pm 7,30$ & 7 & 2 \\
\hline & $2,02 \pm 2,52$ & 14 & 3 \\
\hline & $3,47 \pm 4,50$ & 30 & 2 \\
\hline \multirow{5}{*}{ DP-L2 } & $6,65 \pm 8,53$ & 1 & 3 \\
\hline & $2,60 \pm 2,25$ & 3 & 1 \\
\hline & $4,33 \pm 4,68$ & 7 & 1 \\
\hline & $-\cdots$ & 14 & 0 \\
\hline & $21,67 \pm 6,88$ & 30 & 3 \\
\hline \multirow{5}{*}{ DP-L3 } & $19,10 \pm 15,11$ & 1 & 3 \\
\hline & $13,60 \pm 15,60$ & 3 & 3 \\
\hline & $34,10 \pm 16,26$ & 7 & 3 \\
\hline & $21,38 \pm 9,88$ & 14 & 3 \\
\hline & $29,50 \pm 8,63$ & 30 & 3 \\
\hline
\end{tabular}

Legenda:

$\mathrm{DP}=$ lado com doença periodontal induzida

$\mathrm{V}=$ lado vestibular

$\mathrm{L}=$ lado lingual

1, 2 e 3 = regiões utilizadas para análise em AT 
Quadro 2: Valores médios do número de mastócitos $/ \mathrm{mm}^{2} \pm$ desvios-padrão (dp) utilizados na comparação entre as 3 regiões (1, 2 e 3 ) avaliadas em AT, por cada período de indução experimental da doença periodontal inflamatória $(1,3,7,14$ e 30 dias), para o lado controle das amostras gengivais.

\begin{tabular}{|c|c|c|c|}
\hline Região & Valores Médios $\pm d p$ & Período [dia (s)] & $n$ \\
\hline \multirow{5}{*}{$\mathrm{C}-\mathrm{V} 1$} & $39,02 \pm 38,47$ & 1 & 3 \\
\hline & $31,50 \pm 25,60$ & 3 & 3 \\
\hline & $11,40 \pm 9,28$ & 7 & 3 \\
\hline & $20,00 \pm 3,40$ & 14 & 1 \\
\hline & $16,20 \pm 14,00$ & 30 & 3 \\
\hline \multirow{5}{*}{ C-V2 } & $65,03 \pm 20,40$ & 1 & 3 \\
\hline & $55,50 \pm 35,00$ & 3 & 3 \\
\hline & $44,55 \pm 32,00$ & 7 & 3 \\
\hline & $47,07 \pm 28,46$ & 14 & 3 \\
\hline & $39,60 \pm 27,52$ & 30 & 3 \\
\hline \multirow{5}{*}{$\mathrm{C}-\mathrm{V} 3$} & $7,00 \pm 6,00$ & 1 & 3 \\
\hline & $11,55 \pm 7,22$ & 3 & 3 \\
\hline & $22,00 \pm 19,25$ & 7 & 3 \\
\hline & $13,30 \pm 12,77$ & 14 & 3 \\
\hline & $9,25 \pm 8,90$ & 30 & 3 \\
\hline \multirow{5}{*}{ C-L1 } & $14,16 \pm 11,31$ & 1 & 3 \\
\hline & $10,40 \pm 6,63$ & 3 & 3 \\
\hline & $27,75 \pm 47,11$ & 7 & 3 \\
\hline & $13,90 \pm 15,91$ & 14 & 3 \\
\hline & $9,82 \pm 5,30$ & 30 & 3 \\
\hline \multirow{5}{*}{ C-L2 } & $8,09 \pm 9,85$ & 1 & 3 \\
\hline & $8,09 \pm 9,68$ & 3 & 3 \\
\hline & $35,26 \pm 44,12$ & 7 & 3 \\
\hline & $23,42 \pm 10,70$ & 14 & 2 \\
\hline & $11,27 \pm 9,79$ & 30 & 2 \\
\hline \multirow{5}{*}{ C-L3 } & $19,65 \pm 19,95$ & 1 & 3 \\
\hline & $19,07 \pm 12,20$ & 3 & 3 \\
\hline & $18,05 \pm 18,26$ & 7 & 3 \\
\hline & $30,63 \pm 20,69$ & 14 & 3 \\
\hline & $30,05 \pm 10,00$ & 30 & 3 \\
\hline
\end{tabular}

Legenda:

$C($ Região $)=$ lado controle

$\mathrm{V}=$ lado vestibular

$\mathrm{L}=$ lado lingual

1,2 e 3 = regiões utilizadas para análise em AT 
Figura 15: Representação gráfica dos valores médios do número de mastócitos $/ \mathrm{mm}^{2} \pm$ desvios-padrão obtidos na região 1, nos lados vestibular (A) e lingual (B), dos tecidos periodontais controle e doentes, em cada período de indução experimental da doença periodontal inflamatória (1, 3, 7, 14 e 30 dias).
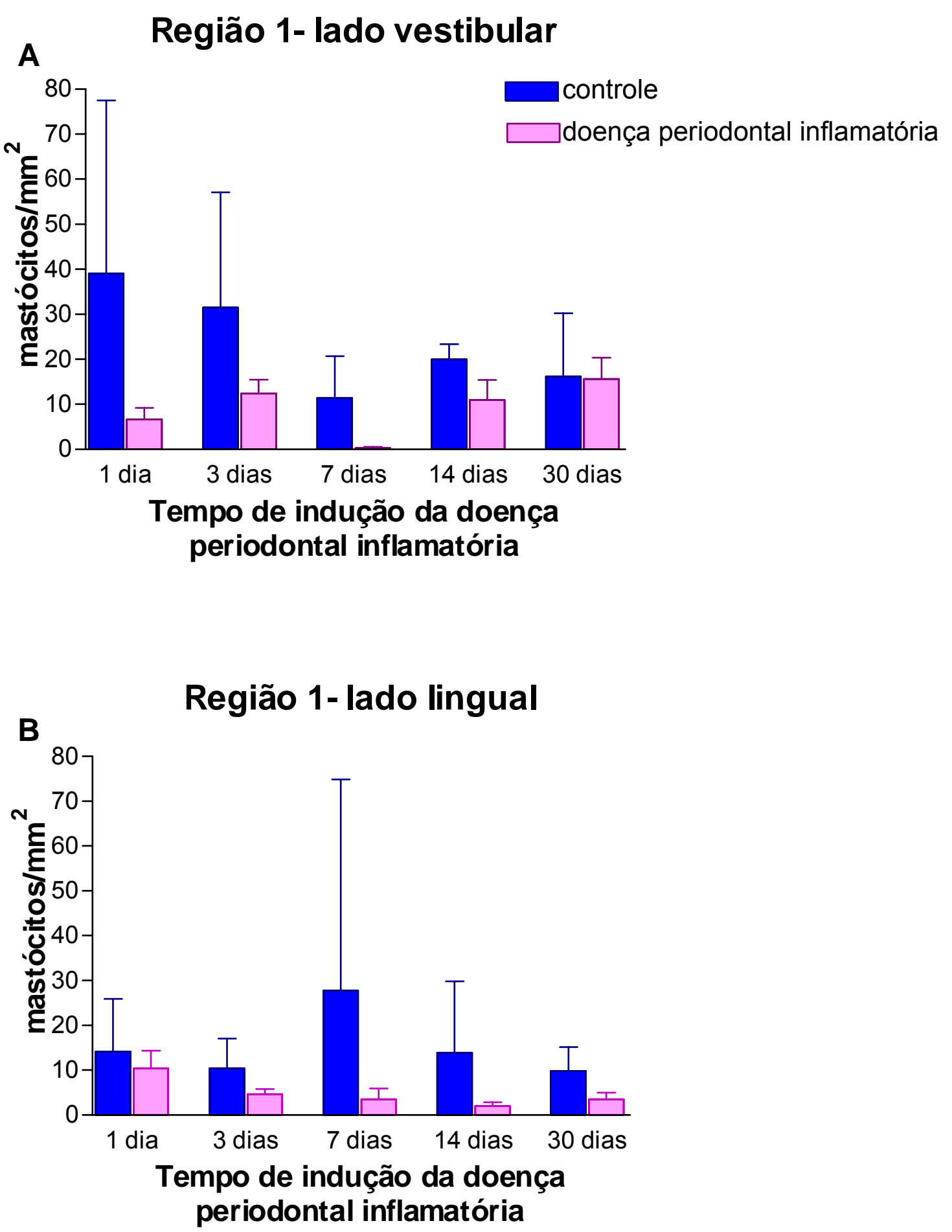
Figura 16: Representação gráfica dos valores médios do número de mastócitos $/ \mathrm{mm}^{2} \pm$ desvios-padrão obtidos na região 2, nos lados vestibular (A) e lingual (B), dos tecidos periodontais controle e doentes, em cada período de indução experimental da doença periodontal inflamatória (1, 3, 7, 14 e 30 dias).
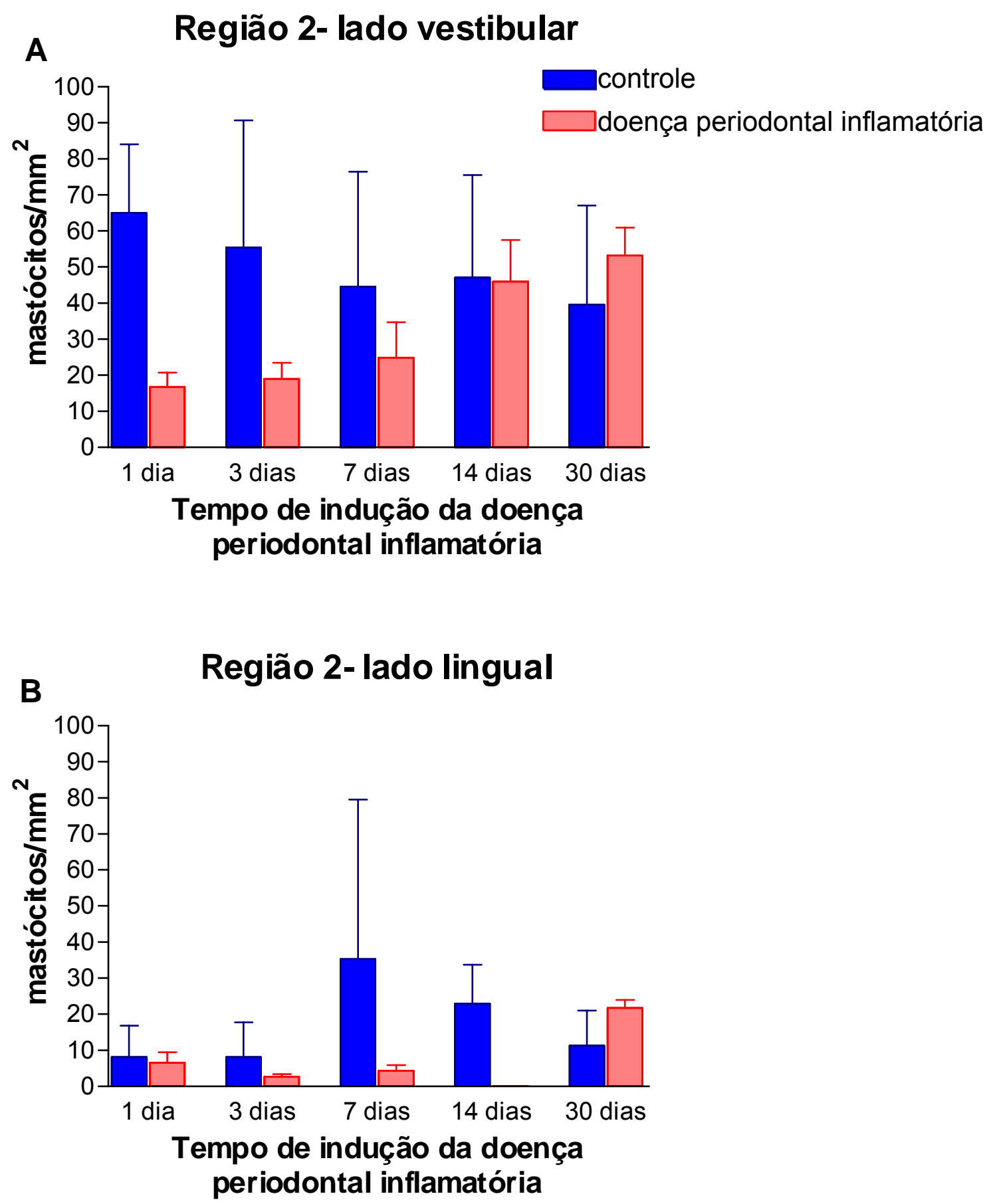
Figura 17: Representação gráfica dos valores médios do número de mastócitos $/ \mathrm{mm}^{2} \pm$ desvios-padrão obtidos na região 3, nos lados vestibular (A) e lingual (B), dos tecidos periodontais controle e doentes, em cada período de indução experimental da doença periodontal inflamatória (1, 3, 7, 14 e 30 dias).

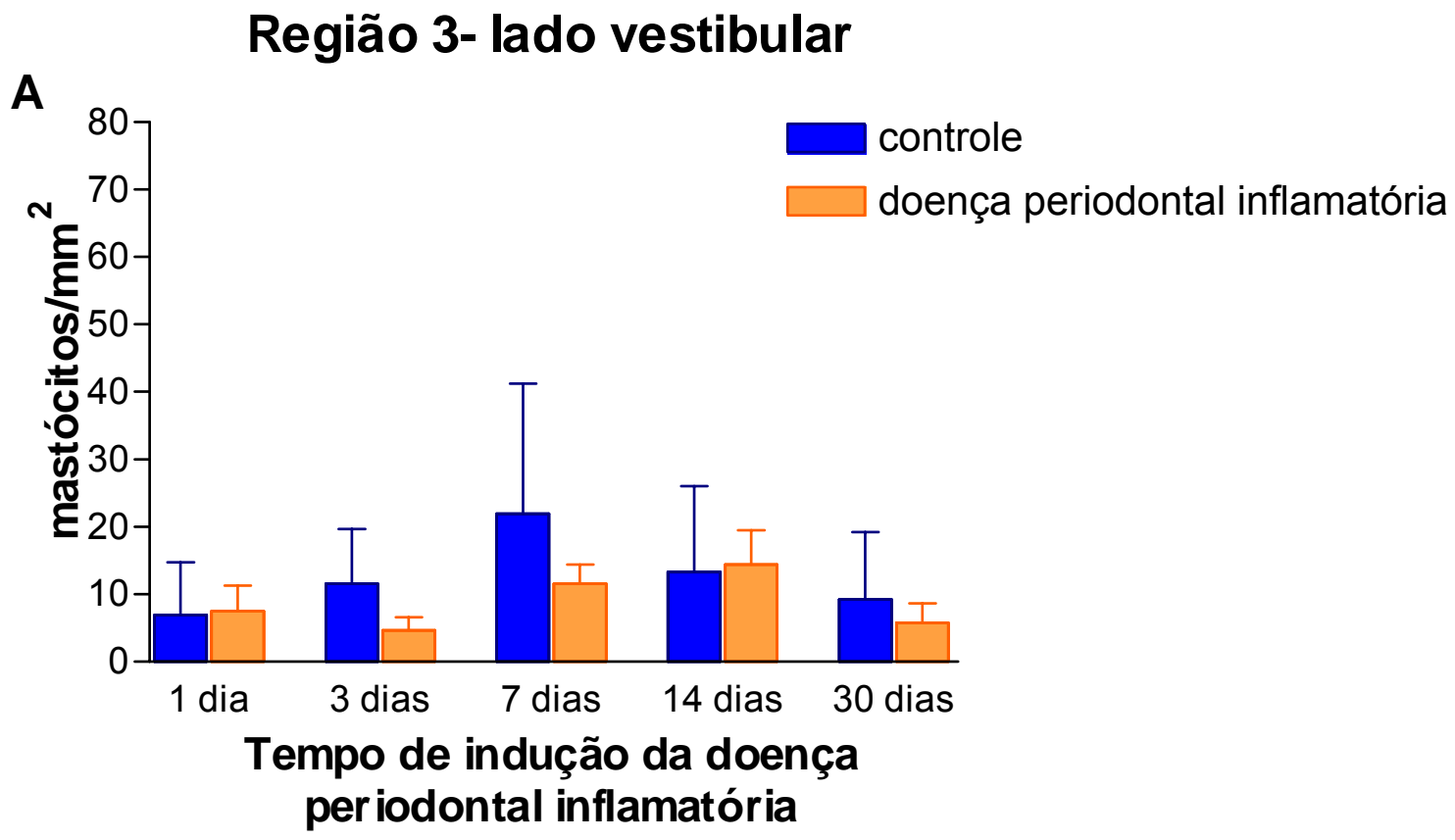

Região 3- lado lingual

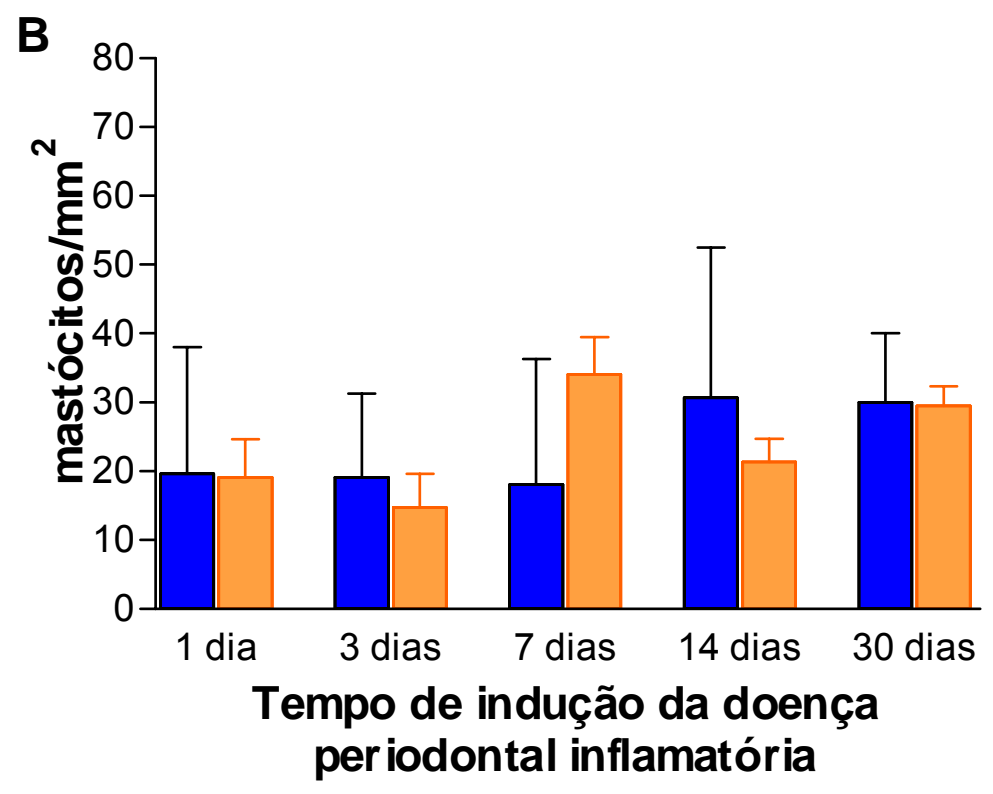


Quadro 3: Comparação geral do número de mastócitos $/ \mathrm{mm}^{2}$ entre controle e doença periodontal inflamatória, pelo teste não paramétrico de Wilcoxon, para cada região (1, 2 e 3; lados vestibular e lingual), independente do período de indução da doença.

\begin{tabular}{|c|c|c|c|c|}
\hline Região & Valores Médios $\pm d p$ & $n$ & Comparações & $P$ \\
\hline DP-V1 & $9,85 \pm 9,09$ & 15 & \multirow{2}{*}{$\mathrm{DP}-\mathrm{V} 1$ x C-V1 } & \multirow{2}{*}{$0,019^{*}$} \\
\hline C-V1 & $24,07 \pm 24,21$ & 13 & & \\
\hline DP-V2 & $31,96 \pm 25,70$ & 15 & \multirow{2}{*}{$\mathrm{DP}-\mathrm{V} 2$ x C-V2 } & \multirow{2}{*}{0,111} \\
\hline C-V2 & $50,35 \pm 26,52$ & 15 & & \\
\hline DP-V3 & $8,78 \pm 6,66$ & 15 & \multirow{2}{*}{$\mathrm{DP}-\mathrm{V} 3$ x C-V3 } & \multirow{2}{*}{0,198} \\
\hline $\mathrm{C}-\mathrm{V} 3$ & $12,60 \pm 9,30$ & 15 & & \\
\hline DP-L1 & $5,10 \pm 5,17$ & 13 & \multirow{2}{*}{ DP-L1 x C-L1 } & \multirow{2}{*}{$0,004^{*}$} \\
\hline C-L1 & $15,20 \pm 14,76$ & 15 & & \\
\hline DP-L2 & $8,60 \pm 7,23$ & 7 & \multirow{2}{*}{ DP-L2 x C-L2 } & \multirow{2}{*}{0,916} \\
\hline C-L2 & $17,20 \pm 18,70$ & 13 & & \\
\hline DP-L3 & $23,52 \pm 11,91$ & 15 & \multirow{2}{*}{ DP-L3 x C-L3 } & \multirow{2}{*}{0,776} \\
\hline C-L3 & $23,50 \pm 15,23$ & 15 & & \\
\hline
\end{tabular}

* diferença estatisticamente significativa $(p<0,05)$

Legenda:

$\mathrm{DP}=$ lado com doença periodontal induzida

$C($ Região $)=$ lado controle

$\mathrm{V}=$ lado vestibular

$\mathrm{L}=$ lado lingual

1,2 e 3 = regiões utilizadas para análise em AT 


\section{5- Análise qualitativa dos mastócitos}

\subsection{1- Tecidos periodontais normais}

Os mastócitos observados nos tecidos controle apresentaram-se dispersos em meio ao tecido conjuntivo fibroso, especialmente na região perivascular, onde eventualmente se arranjavam em aglomerados de células, e próximos a eventuais células inflamatórias. A relação dos mastócitos com os epitélios foi evidente, observando-se grande quantidade de células ATpositivas (mastócitos) logo abaixo dos epitélios gengival, sulcular e juncional, inclusive em seu interior (Figura 18). Profundamente, notou-se grande densidade de mastócitos de permeio às fibras musculares esqueléticas e ao redor de feixes vasculonervosos. 


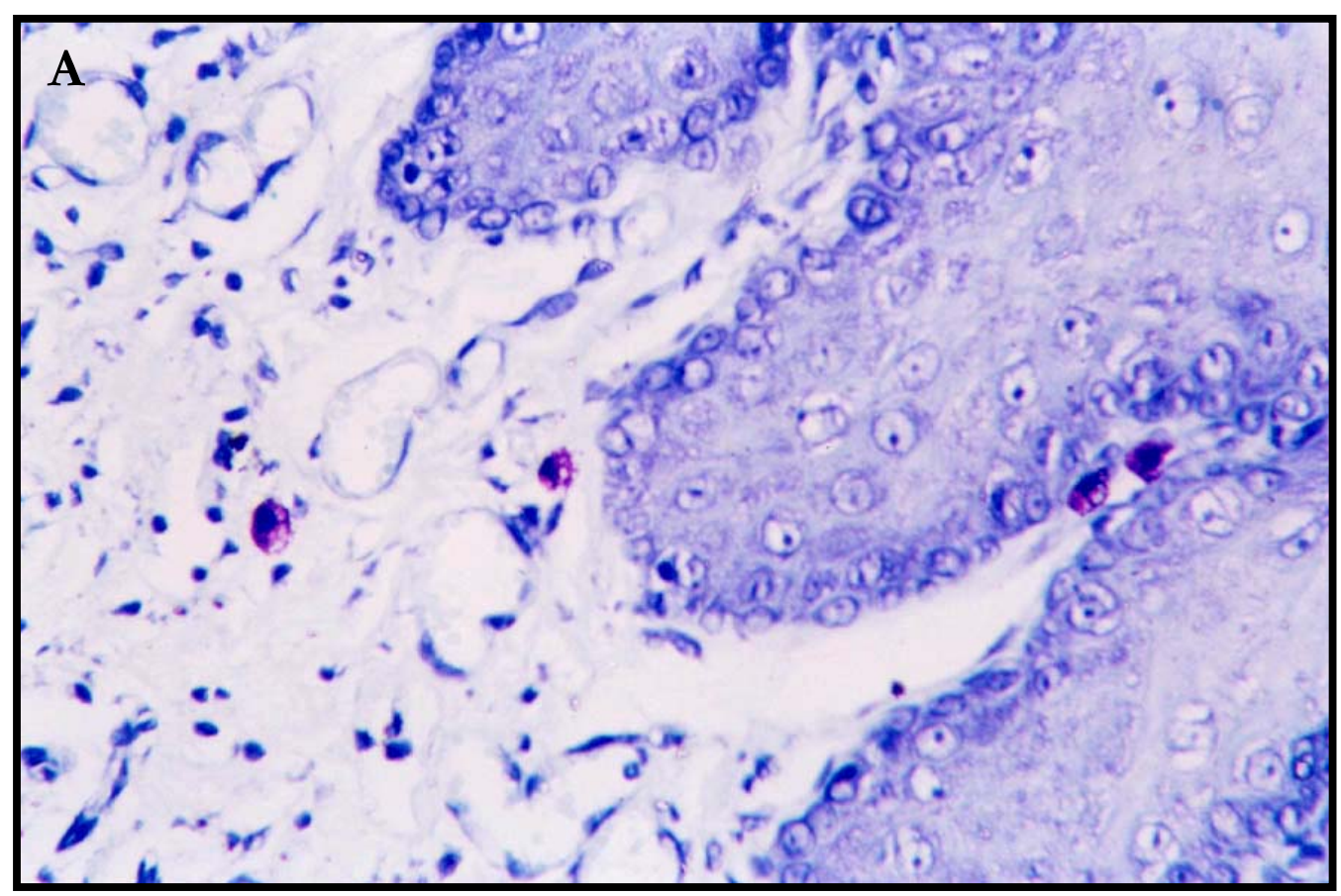

Figura 18: Evidente relação dos mastócitos com os componentes epiteliais da junção dentogengival, logo abaixo dos epitélios gengival (A), sulcular e juncional, inclusive no interior deste (B). (A e B: AT; aumentos originais de 100x; amostras gengivais controle).

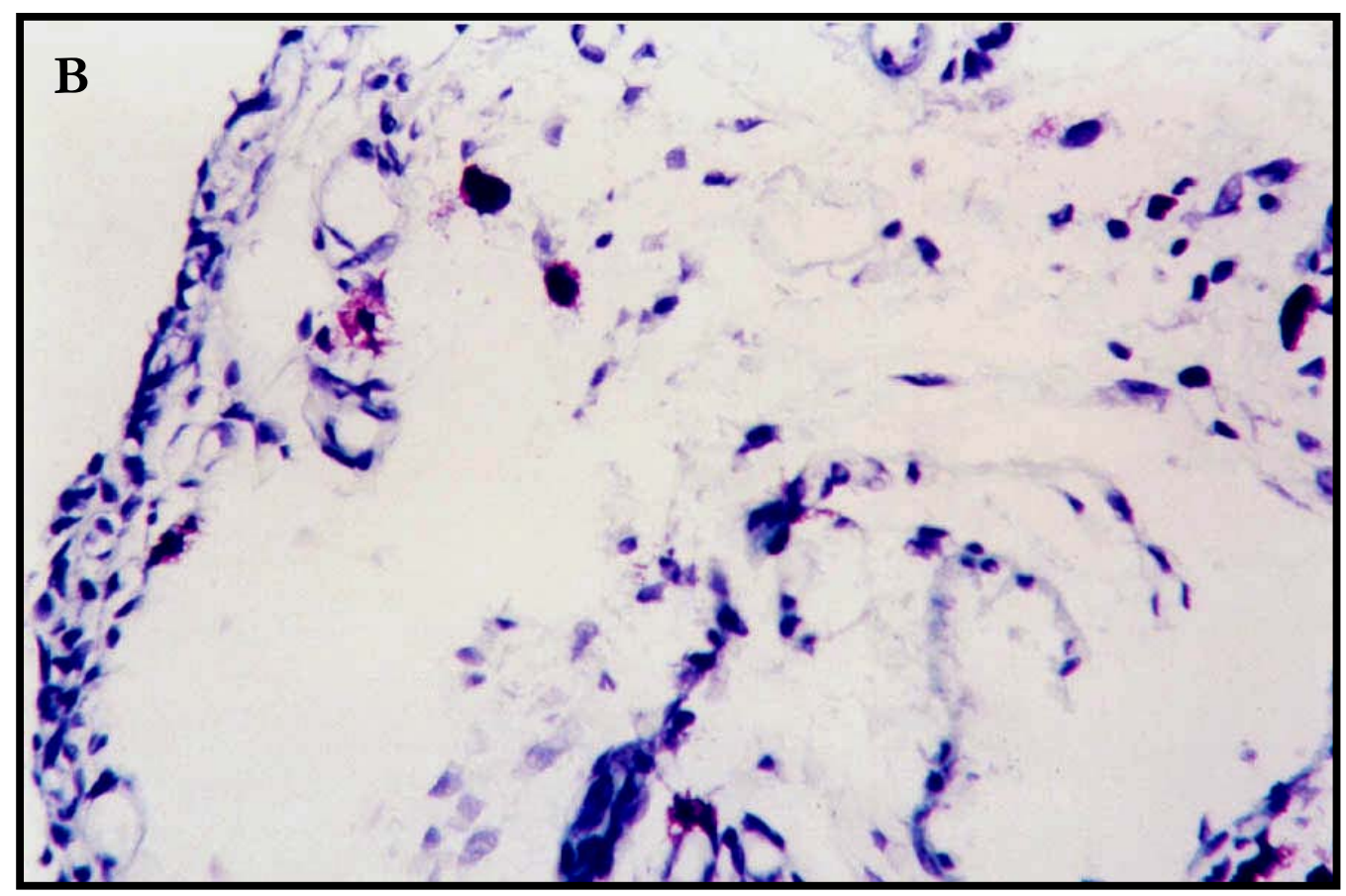




\subsection{2- Tecidos periodontais submetidos ao progressivo acúmulo de placa} dentobacteriana por meio da colocação de ligadura

Nos tecidos doentes, a localização predominantemente perivascular e perineural permaneceu, porém os vasos sangüíneos encontravam-se com grande marginação leucocitária, observando-se proximidade entre os mastócitos e as células MN e PMNs perivasculares (Figura 19). O infiltrado inflamatório composto, principalmente, por PMNs, apresentava-se acompanhado por escassos mastócitos de permeio. A relação dos mastócitos com os epitélios da mucosa gengival, sulcular e juncional, este às vezes já transformado em epitélio de bolsa periodontal, também foi mantida, especialmente na região subjacente ao último. 


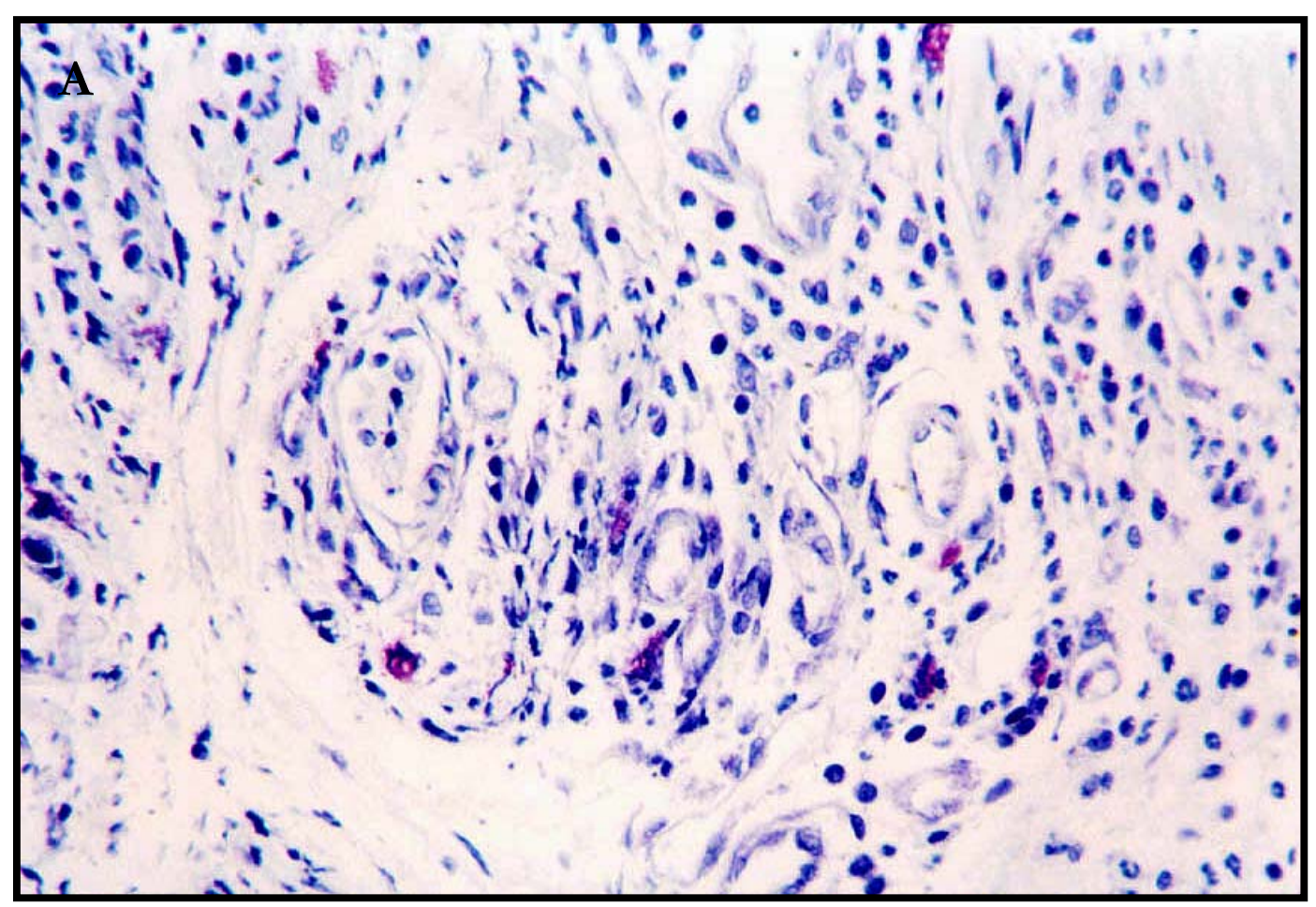

Figura 19: Proximidade entre os mastócitos e as células MN e PMNs presentes no infiltrado inflamatório dos tecidos com doença periodontal inflamatória induzida por 1 dia (A). Em B, observa-se, ainda, a freqüente localização perivascular dos mastócitos no mesmo período de indução. (A e B: AT; aumentos originais 100x e de 250x, respectivamente).

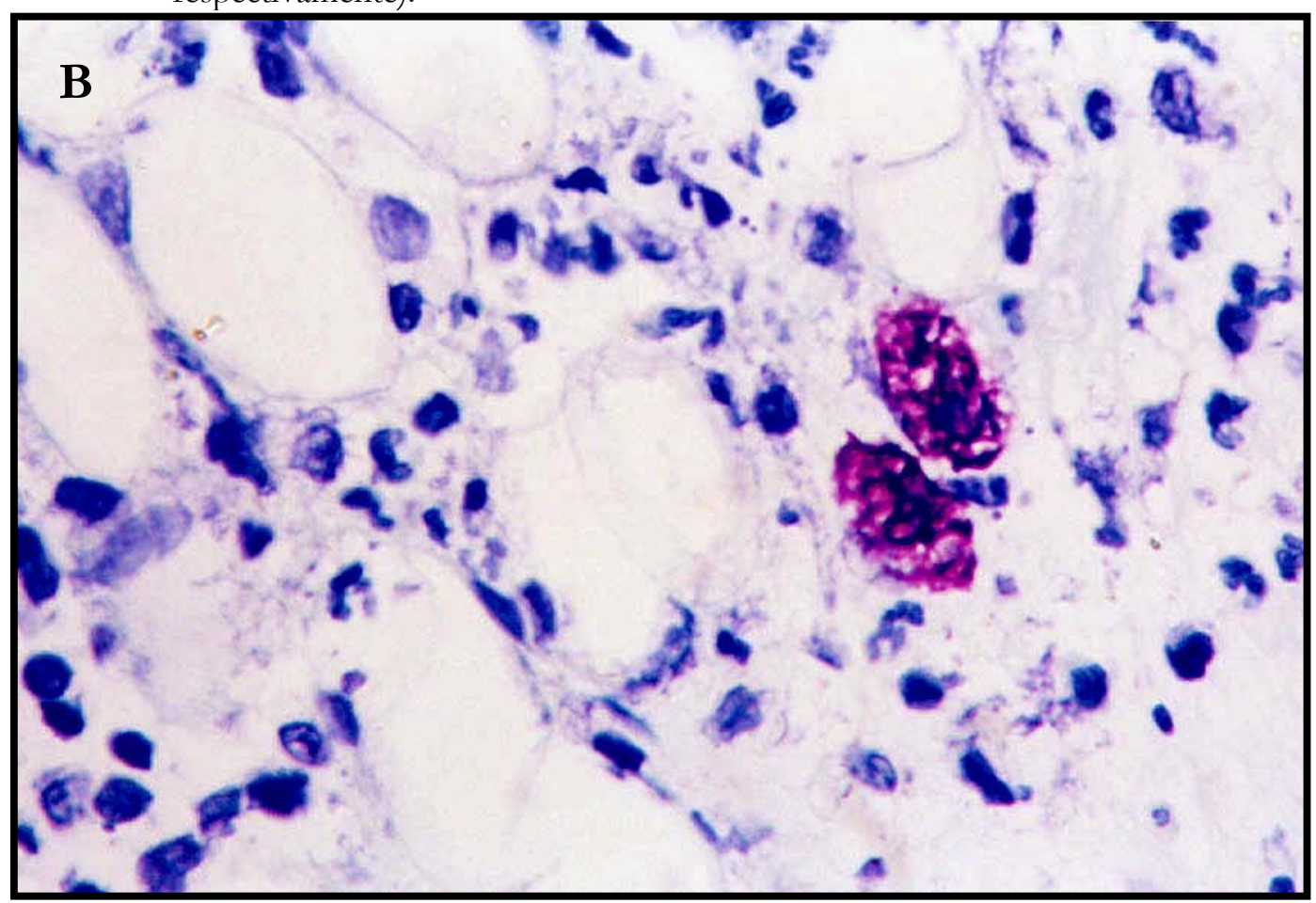




\section{6-Análise molecular}

A partir de uma análise inicial, previamente àquela utilizada para avaliação da intensidade da expressão de $\mathrm{RNA}_{\mathrm{m}}$, não se obteve sinal das reações de PCR para as amostras referentes ao período de 1 dia após a indução experimental tanto para os alvos MMP-2, MMP-9 e iNOS, quanto para os genes de expressão constitutiva, $\beta$-actina e GAPDH. Por se suspeitar de degradação do RNA das referidas amostras, optou-se por remover o período de 1 dia da amostragem.

Ao se comparar a expressão de $\beta$-actina e GAPDH, os valores médios obtidos dos tecidos controle e com doença periodontal não variaram significativamente entre si, para ambos os alvos, confirmando a validade da forma de expressão dos resultados escolhida (Tabela D e Figura 20). Portanto, a presente análise baseou-se somente na relação entre a intensidade das bandas alvo (MMP-2, MMP-9 e iNOS) e a das bandas de $\beta$-actina (Tabela E e Figuras 20 e 21).

O teste de ANOVA relacionou os valores médios entre os níveis de condição periodontal (controle ou doença periodontal) e entre os períodos de indução da doença periodontal, bem como a interação entre condição e estes diferentes períodos. Quando se avaliou a expressão de MMP-2, não se observou diferença estatisticamente significativa com relação a nenhuma das comparações analisadas $(P=0,238, P=0,632$ e $P=0,501$, respectivamente) (Tabela E e Figuras 20 e 21A).

Ao se avaliar a expressão de MMP-9, somente se observou diferença estatisticamente significativa com relação aos valores médios entre os níveis de condição periodontal $(P=0,020)$, sendo negativo para as outras duas comparações $(P=0,130$ e $P=0,275$, respectivamente). Para se especificar entre quais grupos a diferença foi significativa, foi utilizado post hoc de Tukey, que revelou diferença estatisticamente significativa entre os tecidos afetados pela doença periodontal em comparação com o respectivo 
controle nos períodos de 3 e 7 dias $(P=0,007$ e $P=0,014$, respectivamente), revelando uma maior expressão de MMP-9 nos tecidos doentes (Tabela E e Figuras 20 e 21B).

Com relação à iNOS, observou-se diferença estatisticamente significativa com relação aos valores médios entre os níveis de condição periodontal $(P=0,020)$ e entre os períodos de indução da doença periodontal $(P=0,010)$, sendo negativa a interação entre condição periodontal e os diferentes períodos $(P=0,439)$. O post hoc de Tukey revelou diferença estatisticamente significativa entre os tecidos controle e aqueles atingidos pela doença periodontal inflamatória no período de 3 dias $(P=0,036)$, sendo a expressão de iNOS aumentada nos tecidos doentes. O mesmo post hoc também revelou diferença estatisticamente significativa entre tecidos afetados pela doença periodontal inflamatória nos períodos de 3 e 7 dias $(P=$ 0,027), com maior expressão de iNOS aos 3 dias (Tabela E e Figuras 20 e 21C). 
Tabela D: Média e erro padrão da média $(\overline{\mathrm{X}} \pm \mathrm{EPX})$ dos valores de $\beta$-actina e GAPDH obtidos para as condições controle e de doença periodontal nos diferentes períodos.

\begin{tabular}{|c|c|c|c|c|c|}
\hline Período & Condição & $\beta$-actina & $\bar{X}+\mathrm{EPX}$ & GAPDH & $\bar{X}+\mathrm{EPX}$ \\
\hline \multirow{3}{*}{3 dias } & $\mathrm{C}_{1}$ & 1,32 & \multirow{12}{*}{$1,554 \pm 0,074$} & 1,36 & \multirow{12}{*}{$1,510 \pm 0,076$} \\
\hline & $\mathrm{C}_{2}$ & 1,44 & & 1,47 & \\
\hline & $\mathrm{C}_{3}$ & 1,38 & & 2,05 & \\
\hline \multirow{3}{*}{7 dias } & $\mathrm{C}_{1}$ & 1,44 & & 1,54 & \\
\hline & $\mathrm{C}_{2}$ & 1,55 & & 1,97 & \\
\hline & $C_{3}$ & 1,43 & & 1,44 & \\
\hline \multirow{3}{*}{14 dias } & $\mathrm{C}_{1}$ & 2,30 & & 1,55 & \\
\hline & $\mathrm{C}_{2}$ & 1,55 & & 1,35 & \\
\hline & $\mathrm{C}_{3}$ & 1,59 & & 1,32 & \\
\hline \multirow{3}{*}{30 dias } & $\mathrm{C}_{1}$ & 1,43 & & 1,58 & \\
\hline & $\mathrm{C}_{2}$ & 1,50 & & 1,16 & \\
\hline & $\mathrm{C}_{3}$ & 1,72 & & 1,33 & \\
\hline \multirow{3}{*}{3 dias } & $\mathrm{DP}_{1}$ & 1,59 & \multirow{12}{*}{$1,537 \pm 0,079$} & 1,94 & \multirow{12}{*}{$1,440 \pm 0,051$} \\
\hline & $\mathrm{DP}_{2}$ & 1,34 & & 1,45 & \\
\hline & $\mathrm{DP}_{3}$ & 1,19 & & 1,29 & \\
\hline \multirow{4}{*}{7 dias } & $\mathrm{DP}_{1}$ & 1,56 & & 1,32 & \\
\hline & $\mathrm{DP}_{2}$ & 1,12 & & 1,54 & \\
\hline & $\mathrm{DP}_{3}$ & 1,50 & & 1,39 & \\
\hline & $\mathrm{DP}_{1}$ & 2,15 & & 1,44 & \\
\hline \multirow[t]{3}{*}{14 dias } & $\mathrm{DP}_{2}$ & 1,84 & & 1,48 & \\
\hline & $\mathrm{DP}_{3}$ & 1,60 & & 1,45 & \\
\hline & $\mathrm{DP}_{1}$ & 1,61 & & 1,35 & \\
\hline \multirow[t]{2}{*}{30 dias } & $\mathrm{DP}_{2}$ & 1,50 & & 1,27 & \\
\hline & $\mathrm{DP}_{3}$ & 1,44 & & 1,36 & \\
\hline
\end{tabular}

$\mathrm{DP}=$ lado com doença periodontal induzida

$\mathrm{C}=$ lado controle

1,2 e $3=$ amostra 
Tabela E: Relação entre os valores obtidos para os alvos e $\beta$-actina, nas condições controle e de doença periodontal, nos diferentes períodos, com suas respectivas médias e erros padrão da média $\overline{(\mathrm{X}} \pm \mathrm{EPX})$.

\begin{tabular}{|c|c|c|c|c|c|c|c|}
\hline Períodos & Condição & MMP-2 & $\bar{X}+E P X$ & MMP-9 & $\bar{X}+E P \bar{X}$ & iNOS & $\bar{X}+E P \bar{X}$ \\
\hline \multirow{6}{*}{3 dias } & $\overline{C_{1}}$ & 0,62 & 0,520 & 0,36 & 0,340 & 0,89 & 0,930 \\
\hline & $\mathrm{C}_{2}$ & 0,51 & \pm & 0,49 & \pm & 0,74 & \pm \\
\hline & $\mathrm{C}_{3}$ & 0,43 & 0,055 & 0,17 & 0,093 & 1,16 & 0,123 \\
\hline & $\mathrm{DP}_{1}$ & 0,84 & 0,657 & 0,70 & 0,667 & 1,15 & 1,250 \\
\hline & $\mathrm{DP}_{2}$ & 0,84 & \pm & 0,63 & \pm & 1,21 & \pm \\
\hline & $\mathrm{DP}_{3}$ & 0,29 & 0,183 & 0,67 & $0,020^{*}$ & 1,39 & $0,072^{*}$ \\
\hline \multirow{6}{*}{7 dias } & $\mathrm{C}_{1}$ & 0,81 & 0,637 & 0,48 & 0,487 & 0,60 & 0,667 \\
\hline & $\mathrm{C}_{2}$ & 0,49 & \pm & 0,46 & \pm & 0,57 & \pm \\
\hline & $C_{3}$ & 0,61 & 0,093 & 0,52 & 0,018 & 0,83 & 0,082 \\
\hline & $\mathrm{DP}_{1}$ & 0,97 & 0,823 & 0,93 & 0,773 & 0,86 & 0,733 \\
\hline & $\mathrm{DP}_{2}$ & 0,84 & \pm & 0,65 & \pm & 0,73 & \pm \\
\hline & $\mathrm{DP}_{3}$ & 0,66 & 0,090 & 0,74 & $0,083^{*}$ & 0,61 & $0,072^{\#}$ \\
\hline \multirow{6}{*}{14 dias } & $\mathrm{C}_{1}$ & 0,61 & 0,577 & 0,58 & 0,617 & 1,04 & 1,050 \\
\hline & $\mathrm{C}_{2}$ & 0,77 & \pm & 0,75 & \pm & 1,21 & \pm \\
\hline & $C_{3}$ & 0,35 & 0,122 & 0,52 & 0,069 & 0,90 & 0,090 \\
\hline & $\mathrm{DP}_{1}$ & 0,51 & 0,883 & 0,52 & $\overline{0,743}$ & 0,84 & 1,107 \\
\hline & $\mathrm{DP}_{2}$ & 1,11 & \pm & 0,96 & \pm & 1,21 & \pm \\
\hline & $\mathrm{DP}_{3}$ & 1,03 & 0,188 & 0,75 & 0,127 & 1,27 & 0,134 \\
\hline \multirow{6}{*}{30 dias } & $\mathrm{C}_{1}$ & 0,92 & 0,700 & 0,70 & 0,620 & 0,99 & 0,873 \\
\hline & $\mathrm{C}_{2}$ & 0,75 & \pm & 0,70 & \pm & 0,99 & \pm \\
\hline & $C_{3}$ & 0,43 & 0,144 & 0,46 & 0,080 & 0,64 & 0,117 \\
\hline & $\mathrm{DP}_{1}$ & 0,78 & 0,633 & 0,70 & 0,687 & 0,91 & 0,837 \\
\hline & $\mathrm{DP}_{2}$ & 0,55 & \pm & 0,69 & \pm & 0,73 & \pm \\
\hline & $\mathrm{DP}_{3}$ & 0,57 & 0,074 & 0,67 & 0,009 & 0,87 & 0,055 \\
\hline
\end{tabular}

*: diferença estatisticamente significativa em comparação com o respectivo controle.

\#:diferença estatisticamente significativa entre tecidos afetados pela doença periodontal inflamatória, com relação ao grupo de 3 dias.

Legenda:

$\mathrm{DP}=$ lado com doença periodontal induzida

$\mathrm{C}=$ lado controle

1,2 e $3=$ amostra 
Figura 20: Géis de agarose corados com brometo de etídio para observação dos produtos amplificados por RT-PCR a partir de RNA total de tecido gengival de rato obtido após indução da doença periodontal em diferentes períodos. Os cDNAs foram amplificados por PCR com primers específicos para $\beta$-actina, GAPDH, iNOS, MMP-2 e MMP-9.
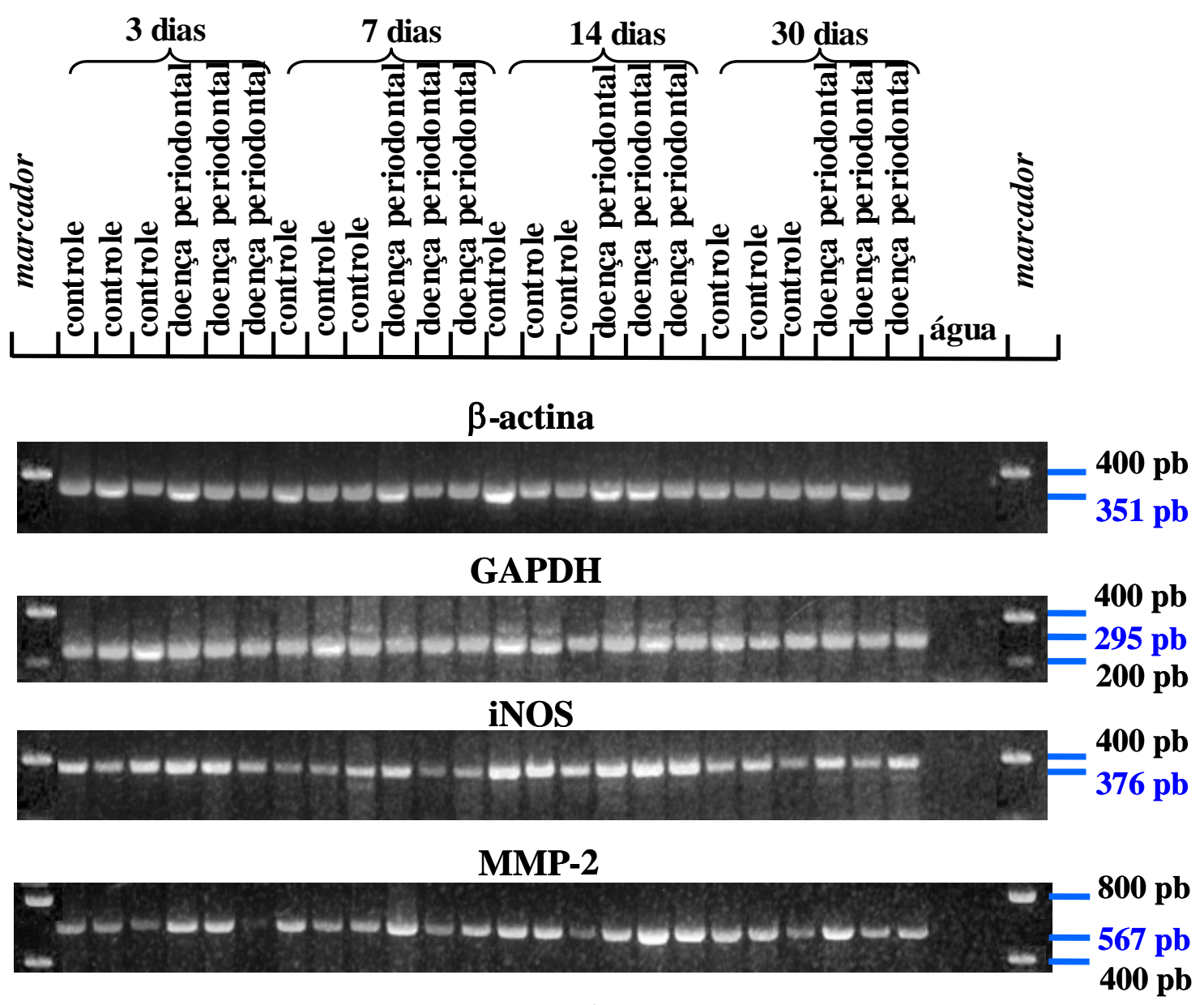

MMP-9

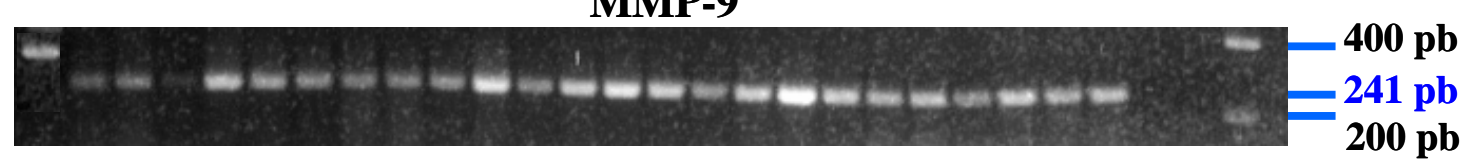

No-RT (GAPDH)

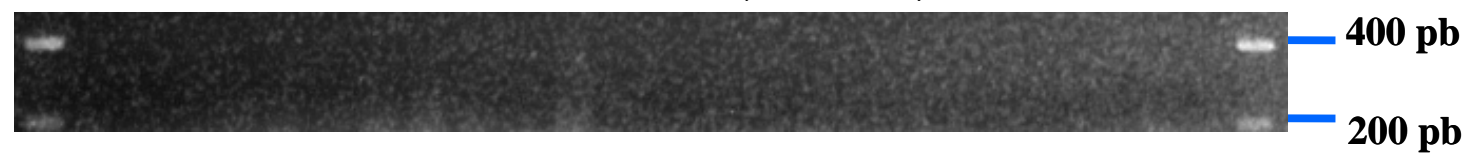


Figura 21: Representação gráfica da expressão relativa de RNAm para MMPs-2 e -9 e iNOS em comparação com $\beta$-actina entre os tecidos afetados pela doença periodontal e seus respectivos controle, bem como os tecidos afetados pela doença periodontal inflamatória entre si.

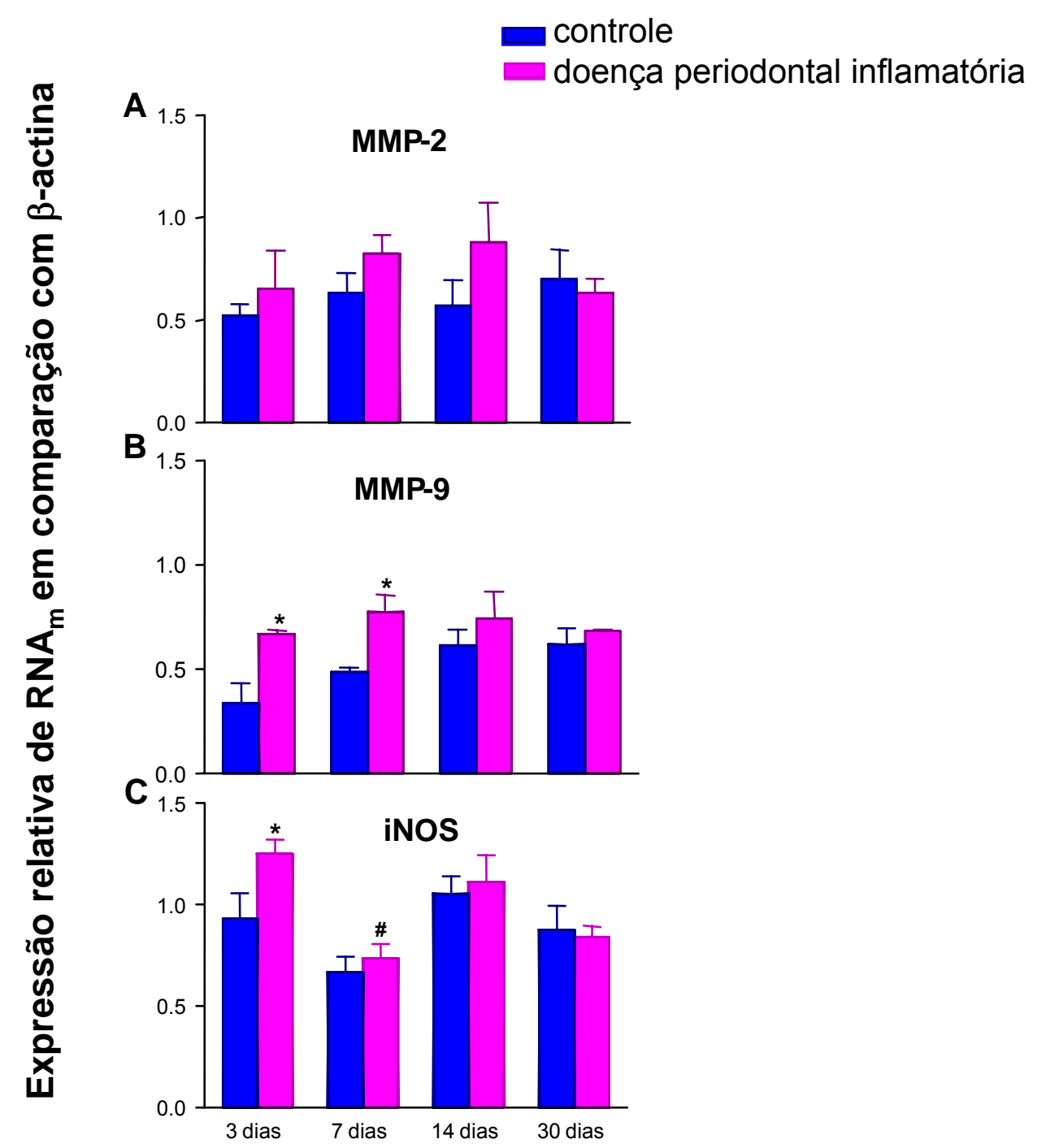

Tempo de indução da doença periodontal

*(B): diferença estatisticamente significativa em comparação com o respectivo controle.

\#(C): diferença estatisticamente significativa entre tecidos afetados pela doença periodontal inflamatória, com relação ao grupo de 3 dias. 


\section{5- DISCUSSÃO}

\section{1- Indução experimental da doença periodontal inflamatória em ratos, por meio de ligadura}

No presente estudo, utilizou-se um modelo experimental de indução da doença periodontal inflamatória bem estabelecido em ratos, que envolve a colocação de uma ligadura ao redor da região cervical do primeiro molar inferior. $\mathrm{O}$ termo ligadura significa faixa, ligamento, por meio de fios de natureza variável, para fins curativo, cirúrgico ou experimental ${ }^{11}$. Modelos experimentais semelhantes já foram utilizados em várias espécies ${ }^{186,}$ 191, 196. Neste modelo, a ligadura age tanto como um fator promotor da formação de placa dentobacteriana quanto como um trauma mecânico na área dentogengival, provocando achatamento e deslocamento dos tecidos gengivais mesial e distal, bem como reduzindo a integridade tecidual pela ulceração ocasional do epitélio sulcular, o que permite uma intensa interação hospedeiro-placa dentobacteriana. A iniciação da doença periodontal inflamatória experimental por bactérias é bem documentada e o resultado final, que envolve destruição do osso alveolar e de outros tecidos conjuntivos, é prontamente observado ${ }^{130}$.

Após a erupção dos molares dos ratos, aos 19, 22 e 35 dias de vida do animal para primeiro, segundo e terceiro molares respectivamente, a função oclusal só é estabelecida aos 25, 28 e 40 dias para primeiro, segundo e terceiro molares respectivamente ${ }^{57}$. Por isso, em nosso trabalho, optou-se pela utilização de animais com idade de 60 ou 120 dias, de acordo com a etapa experimental, quando o ponto de contato já se encontrava bem estabelecido. No entanto, com a idade, conforme a atrição interproximal ocorre, os molares inclinam-se distalmente e, concomitantemente, o osso interdental é estreitado ${ }^{20,85}$, resultando em uma constante remodelação do osso alveolar juntamente com esta migração dentária ${ }^{227}$. Ainda, embora a 
distância entre a junção cemento-esmalte e a crista óssea alveolar permaneça constante nas superfícies vestibulares, um aumento fisiológico dependente da idade pode ser observado em algumas regiões linguais e palatinas ${ }^{5}$.

Esta perda óssea fisiológica resultante dos processos de crescimento e remodelação ósseos que ocorrem nos maxilares, adicionalmente ao rápido atrito oclusal causado pela mastigação, pode constituir, no entanto, uma desvantagem deste modelo animal para a indução experimental da doença periodontal inflamatória, visto que há uma conseqüente movimentação natural dos molares dos ratos $92,202$.

A limitação metodológica devido à reabsorção fisiológica presente nos maxilares de ratos é especialmente crítica quando se propõe a realização de medições da perda óssea utilizando-se como parâmetro a variação da distância entre a junção cemento-esmalte e a crista óssea alveolar em casos de doença inflamatória. No presente trabalho, a presença de reabsorção óssea foi uma constatação microscópica, não havendo qualquer tipo de mensuração, e, ao contrário, o estudo foi baseado na comparação com amostras controle, ou seja, sem colocação da ligadura e oriundas do mesmo animal.

Ainda, com relação à técnica de colocação subgengival da ligadura, alguns autores afirmam que a alteração tecidual resultante é uma reação inflamatória aguda e rápida, ao invés de uma lesão crônica gradualmente progressiva 88,196 . De fato, nossos resultados demonstraram intenso infiltrado inflamatório PMN adjacente aos biofilmes microbianos associados à ligadura desde as primeiras 24 horas de indução, que se manteve até o período de 56 dias.

A possível ulceração da barreira epitelial causada pela inserção da ligadura possibilita a migração de bactérias em direção aos tecidos mais profundos. Entretanto, é possível que o efeito da ligadura, quanto ao acúmulo de placa dentobacteriana, seja perdido através da remodelação óssea que leva à disposição mais coronal da ligadura ao longo do tempo, em 
relação aos tecidos periodontais adjacentes, a partir de períodos maiores que 15 dias da sua colocação ${ }^{117}$. Realmente, em nosso trabalho, foi observada uma diminuição gradativa da inflamação e estagnação da perda óssea alveolar a partir do período de 42 dias de indução da doença periodontal inflamatória.

Neste referido modelo experimental, quanto mais subgengivalmente colocada a ligadura, maior o dano causado nos tecidos periodontais, podendo-se comprometer o papel real do acúmulo de placa dentobacteriana na iniciação e progressão da doença periodontal inflamatória. No entanto, um único episódio de trauma severo parece não influenciar a progressão da doença, seja com relação à perda de adesão entre o tecido conjuntivo e a superfície radicular, ou à perda óssea alveolar ${ }^{172,173}$. Estudos em macacos comprovam que a formação de defeitos ósseos e bolsas periodontais infra-ósseas não está associada com este tipo isolado de trauma, mas com o acúmulo localizado de placa dentobacteriana induzido puramente pela colocação da ligadura143. Assim, a inserção da ligadura com menor trauma possível e sua manutenção subgengival, porém sem destruir completamente a adesão propiciada pela junção dentogengival, possibilita o acúmulo progressivo e espontâneo de placa dentobacteriana composta por bactérias presentes na própria microbiota bucal do animal e causada por sua dieta habitual (ração), sem qualquer manipulação adicional. Apesar de não ser uma doença espontânea, a manipulação do animal para sua indução é feita uma única vez e, a partir de então, a doença periodontal inflamatória progride naturalmente.

Sendo assim, embora conscientes das limitações aqui discutidas, optamos por este modelo experimental, utilizando ligadura, para estudar mais profundamente os achados microscópicos da doença periodontal inflamatória experimental e a presença de algumas moléculas específicas, tomando-se o cuidado de evitar um trauma importante nos tecidos próximos durante a realização da indução. Em seguida, comparamos os aspectos microscópicos apresentados nas amostras de nosso estudo com 
aqueles já conhecidos da doença periodontal inflamatória humana, possibilitando julgar a referida metodologia experimental como vantajosa ou não.

\section{2- Correlações entre Doença Periodontal inflamatória humana e a experimental}

Uma vez bem estabelecida a eficácia da ligadura como fator local de acúmulo de placa dentobacteriana para a indução experimental da doença periodontal inflamatória, é importante definir, então, se os resultados referentes ao modelo são, pelo menos em parte, transponíveis para a doença periodontal humana.

Inicialmente, já podemos ressaltar uma diferença quanto às manifestações clínicas observadas nos diferentes períodos após a indução da doença periodontal inflamatória. Se, em humanos, o edema e o sangramento gengival ao toque associados à presença de placa dentobacteriana são altamente indicativos de doença, em ratos estas alterações não foram tão evidentes, mesmo na presença de acúmulos visivelmente exuberantes de placa dentobacteriana.

Microscopicamente, a doença periodontal inflamatória humana também difere em algumas características daquela induzida em ratos, principalmente com relação à população celular predominante e à distribuição do infiltrado inflamatório. Em humanos, este se caracteriza pela presença predominante de células MNs linfoplasmocitárias com distribuição focal, porém com eventuais macrófagos e focos de PMNs. Esta abundância de linfócitos e plasmócitos, especialmente, está associada com os fenômenos imunopatológicos específicos que direcionam a evolução da doença ${ }^{59}, 69$. Entretanto, no presente trabalho, o que mais se destacou microscopicamente foi a distribuição difusa de células $\mathrm{MN}$ em todos os períodos de indução experimental analisados, em contraste com a abundância de PMNs logo no 
início da doença induzida, com gradativa redução até os períodos mais tardios, distribuídos difusa e predominantemente nas regiões subepiteliais. A intensidade do infiltrado inflamatório, no entanto, decresceu a partir do 420 dia após a colocação da ligadura. Outros autores já haviam descrito que o desenvolvimento da doença periodontal inflamatória em ratos ocorre sem a presença de grandes quantidades de linfócitos e plasmócitos ${ }^{89}$, 189. De acordo com GARANT et al.68, em 1983, o aparecimento de plasmócitos é uma característica predominante nas lesões periodontais avançadas presentes naturalmente em ratos convencionais, paralelamente ao que acontece em humanos, porém muitos meses (20 a 27 meses) são necessários para que estas células se tornem componentes significantes do infiltrado inflamatório da doença em ratos.

Para WEINBERG \& BRAL ${ }^{230}$, em 1999, a diferença observada no padrão do infiltrado inflamatório entre a doença periodontal inflamatória humana e a induzida em ratos é uma limitação da utilização destes animais para se estudar a patogênese da doença.

Provavelmente, o referido modelo experimental não permite o estabelecimento e a progressão do processo inflamatório crônico, uma vez que o fio associado com a placa dentobacteriana acumulada permanece em uma posição estável na região cervical do dente, enquanto os tecidos gengivais migram apicalmente. Conseqüentemente, o fator causal, ou seja, o biofilme microbiano, torna-se cada vez mais distante dos tecidos gengivais, levando ao estabelecimento de um infiltrado inflamatório discreto preferencialmente compatível com um processo de reparo do que com um processo imunopatológico característico das lesões humanas de doença periodontal inflamatória estabelecida e/ou avançada. Associado a isso, em função da anatomia do rato, um processo inflamatório nos tecidos gengivais quase que imediatamente leva à perda óssea, como observamos já no período de 7 dias de nossas amostras acondicionadas previamente em EDTA, seguida de total perda do periodonto de sustentação com desproteção do dente, o 
que não permite tempo suficiente para o estabelecimento de um infiltrado linfoplasmocitário.

Acreditamos que estes aspectos realmente representam uma diferença importante entre a doença periodontal inflamatória em humanos e a experimentalmente induzida em ratos, visto que as principais interações imunopatológicas conhecidamente estudadas na doença humana requerem o envolvimento de linfócitos e plasmócitos. Realmente, a predominância de PMNs na doença periodontal inflamatória em ratos, aliada à ausência de um infiltrado linfoplasmocitário organizado focalmente, não permite a extrapolação perfeita dos resultados obtidos no presente trabalho para o que ocorre em humanos. Por outro lado, alguns autores, utilizando injeção local de periodontopatógenos, observaram grande semelhança entre o infiltrado inflamatório presente no tecido conjuntivo de lesões periodontais experimentalmente induzidas em ratos e aquele das lesões humanas, contendo linfócitos T e B, macrófagos e PMNs neutrófilos 97, 108, 219.

Em nosso estudo, com relação à reabsorção óssea, esta começou a ser observada microscopicamente a partir do período de 1 dia, parecendo atingir seu pico aos 14 dias após a indução da doença periodontal inflamatória. Entretanto, a partir do período de 42 dias, notou-se desaceleração no processo de perda óssea alveolar, provavelmente devido ao distanciamento da fonte agressora (fio e placa dentobacteriana) com relação aos tecidos periodontais do rato, especialmente o epitélio da bolsa periodontal, hiperplásico e migrado apicalmente. Nossos resultados estão de acordo com vários outros trabalhos envolvendo a mesma metodologia de indução da doença periodontal inflamatória em ratos, macacos e beagles, que relataram maior exuberância da inflamação e da perda óssea alveolar nas primeiras duas semanas após a colocação da ligadura, com diminuição consistente e gradual até os períodos mais avançados de indução 2, 117, 160 .

WEINBERG \& BRAL230, em 1999, relataram que, ao invés de a lesão periodontal em ratos se estender ao longo da raiz dentária, como ocorre 
em humanos, sua extensão mais apical localiza-se na altura dos tecidos interdentais. HEIJEL et al. ${ }^{89}$, em 1980, observaram ainda, que a perda óssea observada em ratos pode ocorrer mesmo sem a migração apical do epitélio juncional. No entanto, em nossas amostras, a reabsorção óssea alveolar foi evidente, atingindo as faces mesial, inter-radicular e distal do primeiro molar inferior direito, e evoluiu gradativamente para as regiões mais apicais, aparentemente comprometendo o suporte dentário já no período de 28 dias após a indução da doença. Além disso, foram observadas, em todas as lâminas de tecidos doentes, a migração apical do epitélio da bolsa periodontal. Acreditamos, porém, que talvez uma análise comparativa entre amostras humanas e de ratos possa revelar algumas diferenças com relação ao padrão, velocidade e intensidade da perda de suporte dentário, bem como à disposição espacial do tecido mole, provavelmente por sutis diferenças na disposição das fibras dos ligamentos gengival e periodontal, e no metabolismo ósseo. Entretanto, as características básicas de acentuada perda óssea alveolar e formação da bolsa periodontal são bem definidas no modelo experimental utilizado, o que não foi observado nas amostras controle, fortalecendo o papel da placa dentobacteriana e do fio de seda como um fator local para o acúmulo da referida placa na iniciação da doença periodontal inflamatória.

No que diz respeito à reabsorção dentária, um fenômeno incomum tanto em dentes humanos saudáveis quanto suportados por um periodonto doente, é freqüentemente observada em dentes de rato, sendo até denominada de reabsorção fisiológica. Esta se inicia tão cedo o dente entre em oclusão, ao redor de 4 semanas de idade, e pode ser provocada por qualquer trauma dentário, incluindo atrição oclusal ${ }^{20}$. Entretanto, não é rampante, o que sugere que deve existir um mecanismo protetor no ligamento periodontal, que pode estar relacionado com o sistema formado pelos restos epiteliais de Malassez. De fato, em nossas amostras tanto 
controle como com doença periodontal inflamatória, embora a superfície cementária se apresentasse, em sua maioria, uniforme e regular, revestida por cementoblastos, foram observadas freqüentes áreas de reabsorção dentária paralisada e/ou de superfície irregular, bem como reparada, em especial nas regiões mais cervicais. Também distribuídas especialmente no terço cervical, das regiões interproximal e inter-radicular do hemiarco submetido à colocação de ligadura, observaram-se ilhotas de epitélio odontogênico de variados tamanhos no ligamento periodontal, compatíveis com restos epiteliais de Malassez.

Se por um lado há diferenças entre homem e rato com relação à doença periodontal inflamatória, por outro há muitas semelhanças. Em ambos, a primeira barreira contra a instalação da doença periodontal inflamatória é a presença do epitélio juncional. Sua composição por populações celulares distintas em diferentes regiões anatômicas, todas com fenótipo responsivo, permite-lhes exibir funções específicas na defesa periodontal, assim como adquirir ou perder papel ativo durante a progressão da doença periodontal inflamatória. Desta forma, suas células e funções antimicrobianas formam, juntas, a primeira linha de defesa contra a invasão tecidual microbiana. Além da barreira seletiva formada pelas lâminas basais gengivais, os componentes inflamatórios e imunológicos de defesa atravessam facilmente a membrana basal e o epitélio em direção ao sulco gengival. Neste local, estes componentes têm papel importante na restrição do acesso bacteriano aos tecidos subgengivais ${ }^{112}$. Leucócitos, especialmente PMNs neutrófilos, que migram pelo epitélio juncional, constituem, provavelmente, o mecanismo de defesa mais importante da margem gengival $^{167}$. Este evento pôde ser claramente observado em nosso trabalho, cujas amostras de doença periodontal inflamatória revelaram intensa exocitose por PMNs neutrófilos em direção aos exuberantes biofilmes microbianos localizados na superfície dentária, inclusive freqüentemente circundando-os. 
Modelos animais têm sido largamente utilizados em benefício da compreensão da patogênese da doença periodontal inflamatória e na avaliação de suas variadas modalidades terapêuticas. Embora não se possam esperar respostas idênticas a agressões semelhantes entre as diferentes espécies, modelos animais podem funcionar como modelos de tendências biológicas e fornecer informações impossíveis de se obter em humanos. Neste sentido, os ratos geralmente são alvo de estudos experimentais da doença periodontal inflamatória, devido às grandes semelhanças com os humanos em relação à arquitetura da região de molares, inclusive da junção dentogengival, baixo custo da pesquisa, fácil manuseio e disponibilidade de utilização de várias raças com diferentes estados microbiológicos e imunológicos 108 , 124, 230. Além disso, estudos longitudinais da doença periodontal inflamatória em humanos levantam vários problemas como a determinação do nível da atividade da doença, riscos individuais e suscetibilidade à progressão da doença. Então, é importante escolher um modelo animal experimental que compartilhe características semelhantes com relação à anatomia e à doença periodontal inflamatória humana ${ }^{230}$.

Embora várias diferenças clínicas e microscópicas possam ser citadas entre a doença periodontal inflamatória humana e aquela induzida em ratos, a anatomia periodontal semelhante entre ambos bem como a analogia quanto ao desenvolvimento e composição da placa dentobacteriana e, em parte, quanto aos aspectos histopatológicos tornam a indução experimental da doença periodontal inflamatória em ratos um modelo aceitável para se extrapolar os resultados obtidos com relação à mesma doença em humanos ${ }^{108}$, porém somente quanto aos seus fenômenos iniciais. Entre as inúmeras vantagens de se estudar uma doença experimentalmente induzida é poder observar, desde por meio da mais tradicional metodologia (como por exemplo a coloração por HE) até aquelas mais variadas e modernas, seu curso ao longo do tempo, a fim de se compreender sua patogênese e definir a melhor forma de tratá-la. 


\section{3- Comparação entre as diferentes amostras obtidas}

Um dos objetivos do presente trabalho foi caracterizar o modelo experimental da doença periodontal inflamatória induzida por ligadura em ratos. Para isso, foram analisados cortes microscópicos dos tecidos duro e mole, previamente mantidos em EDTA, e de amostras gengivais, como se fossem material de biópsia. Comparando-se as imagens obtidas em HE, podemos destacar a riqueza de detalhes fornecida pela observação microscópica dos tecidos submetidos ao tratamento com EDTA, principalmente com relação à preservação da integridade dos epitélios juncional e da bolsa periodontal. Mesmo no lado controle já se observou um achado microscópico interessante. Enquanto em dentes humanos saudáveis sabemos que o epitélio juncional termina na junção cemento-esmalte, em ratos, observamos uma discreta localização apical do epitélio juncional com relação à junção cemento-esmalte na região mesial do primeiro molar inferior.

Os cortes obtidos a partir do tratamento com EDTA possibilitaram uma visão global da relação entre primeiro e segundo molares inferiores, revelaram a íntima associação do fio com a junção dentogengival do primeiro molar inferior direito, evidenciaram o conseqüente acúmulo de agregados e biofilmes microbianos no fio e na própria superfície dentária, revelaram a disposição do infiltrado inflamatório, inclusive nas proximidades do tecido ósseo, bem como proporcionaram a análise do dente com ligadura em suas faces mesial, inter-radicular e distal, e o estudo do tecido ósseo. Portanto, embora a utilização de EDTA prolongue o tempo para obtenção dos resultados, a análise dos tecidos submetidos a este tratamento é extremamente válida, permitindo uma análise mais detalhada da relação entre os vários tecidos. Ainda, pudemos definir os períodos iniciais como os mais representativos da indução da doença em ratos, quando já se observam alterações significativas na junção dentogengival e estabelecimento do 
processo de reabsorção óssea. Após os 14 dias de indução experimental, as características microscópicas não apresentaram alterações importantes, talvez devido ao distanciamento da fonte agressora com relação aos tecidos gengivais. Além disso, o elevado metabolismo destes animais acelera a cinética de evolução da doença, o que acaba permitindo um estudo longitudinal em menor tempo, ao se comparar com outras espécies. Contudo, não se pode descartar a possibilidade de, no período de 1 dia, ocorrer alterações inflamatórias decorrentes do próprio procedimento de colocação da ligadura. Em resumo, podemos sugerir que, para trabalhos futuros utilizando a metodologia apresentada, a indução experimental até o período de 14 dias é suficiente para uma avaliação dos fenômenos inflamatórios em resposta aos biofilmes microbianos aderidos à superfície dentária, simulando a doença periodontal inflamatória, particularmente nas suas fases iniciais, em que se evidencia a resposta imune inata.

As amostras gengivais, por sua vez, foram isentas do tratamento prévio com EDTA, o que traz vantagens quanto à utilização de determinadas colorações especiais, como por exemplo o AT, bem como de imuno-histoquímica e de técnicas de biologia molecular, o que, exceto a imuno-histoquímica, foi realizado no presente trabalho. 


\section{4- MMPs na doença periodontal inflamatória experimental}

A evidência do papel das MMPs na destruição tecidual presente na doença periodontal inflamatória é forte e tem sido suportada por inúmeros achados, como a detecção de níveis elevados de colagenases em tecidos gengivais doentes in vitro ${ }^{64}$, em fluido de bolsas periodontais e em extratos de tecidos gengivais inflamados, bem como de RNAm para MMP em fibroblastos gengivais e periodontais, queratinócitos, células endoteliais, osteoblastos e até mesmo osteoclastos. Entre as células inflamatórias, os PMNs neutrófilos parecem ter papel particular na produção de MMP, na doença periodontal destrutiva ${ }^{74,75,120,209}$.

A liberação de proteinases pelas células envolvidas na doença periodontal inflamatória ocorre em resposta à bactéria e às citocinas inflamatórias, como IL-1, TNF- $\alpha$, fator transformador do crescimento alfa (TGF- $\alpha$ ), fator de crescimento epidérmico (EGF), FGF-2 e fator de crescimento derivado de plaquetas $(\mathrm{PDGF})^{1}$, 22, 135. A regulação dos mecanismos de ativação das MMPs tem um papel fundamental na progressão da doença periodontal inflamatória136, 210. Estas enzimas contribuem para a destruição tecidual periodontal por meio da degradação da matriz extracelular e de componentes das membranas basais ${ }^{23}$, 209, assim como aceleram a perda óssea alveolar 76,213 . Vários estudos indicam que, durante a doença periodontal inflamatória, ocorre um desequilíbrio entre as proteinases e seus inibidores (TIMPs), a favor das proteinases, resultando em destruição tecidual3, 118, 208. Em modelos experimentais de inibição das MMPs, a doença periodontal inflamatória torna-se menos severa ${ }^{1,179}$. Alguns autores têm extrapolado estes resultados e proposto a inibição das MMPs como terapia coadjuvante na doença humana $158,188$.

No caso das MMPs-2 e -9, a ativação de seus mecanismos de liberação pode ocorrer, preferencialmente, via degranulação de PMNs neutrófilos durante a destruição periodontal, embora vários tipos celulares 
presentes no periodonto, incluindo fibroblastos gengivais e do ligamento periodontal, macrófagos, queratinócitos, células endoteliais, osteoblastos,

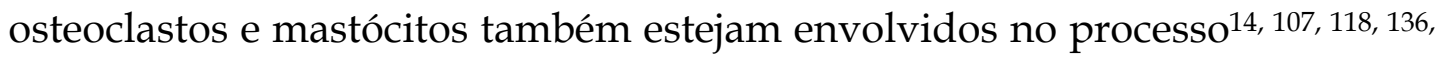
$145,187,210,237$.

O presente estudo permitiu a análise da expressão de RNAm das MMPs -2 e -9 em tecidos gengivais de rato afetados pela doença periodontal inflamatória induzida por ligadura e em seus respectivos controles. Ao se comparar a expressão relativa de RNAm de MMP-9 com relação à expressão de $\beta$-actina, observou-se expressão significativa da enzima nos tecidos afetados pela doença periodontal inflamatória em comparação com o respectivo controle, nos períodos de 3 e 7 dias pósindução ( $P=0,007$ e $P=0,014$, respectivamente). No entanto, com relação à expressão de MMP-2, não se observou diferença estatisticamente significativa com relação a nenhuma das comparações analisadas, ou seja, entre a condição periodontal, entre os períodos de indução da doença periodontal inflamatória e relacionando-se a condição periodontal nos diferentes períodos de indução $(P=0,238, P=0,632$ e $P=0,501$, respectivamente).

Nossos resultados estão de acordo com MAKELA et al. ${ }^{136}$, em 1994, DAHAN et al.44, em 2001 e SMITH et al.205, em 2004, que, embora tenham utilizado metodologias diferentes e suas amostragens consistissem de tecidos gengivais humanos, detectaram a expressão, atividade e a forte imunorreatividade para MMP-9 em amostras de pacientes com doença periodontal inflamatória, sem expressão significante de MMP-2. A imunopositividade para MMP-9 foi encontrada em células epiteliais juncionais e de bolsa gengival, principalmente no interior de queratinócitos, assim como forte imunomarcação ocorreu em PMNs neutrófilos realizando leucodiapedese, e observaram-se ainda dispersos depósitos ao longo do tecido conjuntivo afetado pela doença periodontal inflamatória. Essa imunomarcação em queratinócitos e leucócitos provavelmente relaciona-se 
com migração celular e dissolução das fibras do ligamento periodontal. Por outro lado, em ratos, ACHONG et al. ${ }^{1}$, em 2003, observaram aumento da presença de MMP-2 latente (pro-MMP-2) e ativa em amostras de doença periodontal inflamatória experimentalmente induzida por ligadura aos 7 e 21 dias.

Considerando-se, ainda, que níveis elevados de alguns periodontopatógenos estejam associados com a doença periodontal inflamatória crônica, um ou grupos destes podem exercer efeito estimulatório direto na produção de RNAm para MMP. Tal efeito estimulatório já foi previamente descrito em sistemas in vitro com relação à produção de MMP-9 e colagenase ${ }^{62,223}$, assim como de MMP-2181. Estes achados suportam a hipótese de uma ação direta dos periodontopatógenos sobre os fibroblastos gengivais, com relação à produção de MMP-9 em nossas amostras, além das citocinas.

A progressão da doença periodontal inflamatória é caracterizada pela alternância entre períodos de destruição tecidual e períodos de remissão. A ativação de pró-formas de enzimas degradativas, como as MMPs, armazenadas nos tecidos, pode induzir um período repentino de atividade da doença, enquanto, no período de remissão, um equilíbrio é readquirido pelo aumento das TIMPs. Quando a resposta inflamatória se ativa novamente, um reservatório de pró-enzimas é gradualmente secretado e armazenado na matriz extracelular e, após ativação, um novo surto de doença ocorre. No entanto, pouco se sabe sobre a atividade e a porcentagem de formas ativas de qualquer enzima nos tecidos, especialmente durante as fases ativas da doença periodontal inflamatória ${ }^{163}$.

A MMP-9 é o membro mais complexo da família das MMPs com relação à estrutura da proteína e regulação de sua atividade e, em contraste com outras gelatinases, como a MMP-2, é produzida por um número limitado de células e de maneira não constitutiva, responsiva a fatores de crescimento e citocinas. O colapso do tecido periodontal tem sido 
associado com a conversão de pró-MMP-9 em sua forma ativada, no próprio fluido gengival222. A ativação da MMP-9 nos estágios mais precoces do colapso periodontal pode ser responsável pela destruição da membrana basal, enquanto que em uma fase destrutiva da doença pode contribuir para parte da reabsorção óssea alveolar e radicular. Após a solubilização da matriz óssea, debaixo da "borda em escova" dos osteoclastos, a exposição da matriz orgânica a torna suscetível à ação das MMPs, especialmente à MMP-9, conhecidamente a mais abundante em osteoclastos. Finalmente, durante a remodelação e a fase de reparo teciduais da lesão periodontal, a MMP-9 ativada pode permitir a migração celular e a reconstrução da matriz extracelular. Portanto, com relação ao tecido ósseo, especificamente, as MMPs não agem somente como solubilizadoras da matriz previamente desmineralizada pela ação dos clastos, mas também como reguladoras da posterior formação do tecido ósseo ${ }^{45}$. Realmente, em nosso trabalho, podemos correlacionar as observações microscópicas com o significativo aumento da expressão de RNAm para MMP-9 no período de 7 dias, pelo tecido gengival afetado pela doença periodontal inflamatória em comparação ao seu respectivo controle. Neste período, notaram-se áreas marcantes de reabsorção óssea tanto nas regiões mais superficiais quanto profundas da face óssea alveolar, onde se observaram inúmeros osteoclastos nas superfícies das regiões mesial, de furca e distal do primeiro molar inferior direito. Essa expressão elevada de MMP-9 sofreu discreto decréscimo gradativo, embora não estatisticamente significativo, nos tecidos afetados pela doença, nos períodos de 14 e 30 dias. Interessantemente, COROTTI ${ }^{42}$, em 2005, a partir da indução experimental de lesões periapicais em ratos, demonstrou intensa expressão imuno-histoquímica de MMP-2 e -9 principalmente nas áreas de infiltrado inflamatório das referidas lesões, nos períodos de 7 a 20 dias, bem como nas células do ligamento periodontal próximas destas lesões. Ainda, com relação ao mesmo trabalho, as células sugestivas de osteoblastos e osteoclastos próximas às lesões apresentaram 
imunomarcação suave para MMP-2 e -9 em todos os períodos analisados. Embora, em nosso trabalho, não se tenha realizado a marcação imunohistoquímica das MMPs-2 e -9 e a etiologia das lesões periapicais e periodontais sejam distintas, podemos sugerir, correlacionando os dois trabalhos, que a MMP-9 pode estar envolvida na indução da osteoclastogênese e conseqüente reabsorção óssea na doença periodontal induzida por ligadura em ratos.

As MMPs podem ser vistas como "escavadeiras” destruidoras da matriz extracelular, envolvidas tanto em processos fisiológicos, como o desenvolvimento, remodelação e reparo teciduais, quanto na destruição tecidual142, 224. Entretanto, a visão de que as MMPs funcionem apenas como "armas de destruição em massa" da matriz extracelular é muito simplista. A matriz extracelular possui muitas outras funções além de seu papel estrutural e de barreira; a membrana basal influencia o crescimento e a sobrevivência das células epiteliais, e a matriz extracelular funciona como um reservatório para uma variedade de moléculas biologicamente ativas ${ }^{28}$. Portanto, a proteólise de componentes da matriz extracelular pelas MMPs pode alterar muitas funções, assim como resultar na liberação de fragmentos com atividades biológicas distintas ${ }^{232}$.

Sabe-se que as MMPs também desempenham papel importante na regulação da comunicação intercelular e funções imunes por meio do processamento de moléculas bioativas, incluindo receptores celulares de superfície, citocinas, hormônios, moléculas de adesão e fatores de crescimento $^{214}$. Assim, as MMPs podem regular a biodisponibilidade e/ou atividade de fatores de crescimento tanto pela clivagem de substratos, visto que muitos fatores de crescimento (FGF, TGF) têm forte afinidade pelos componentes da matriz e que a proteólise de suas moléculas específicas resulta na solubilização dos fatores associados, quanto pela mediação do turnover de receptores ${ }^{142}$. 
$\mathrm{Na}$ doença periodontal inflamatória, embora a expressão de MMPs por células epiteliais gengivais tenha sido freqüentemente associada com migração celular, estudos recentes em camundongos deficientes de MMP-9 têm proposto uma discreta participação desta enzima na inibição da taxa de regeneração epitelial, exercendo um controle negativo sobre a taxa de migração de células epiteliais, bem como na regulação da resposta inflamatória durante o reparo tecidual ${ }^{148}$.

Em resumo, os eventos de clivagem das MMPs estão associados tanto com a estimulação quanto com a repressão da proliferação celular, aumento ou inibição da apoptose e aumento ou inibição da quimiotaxia e migração celulares. O conseqüente envolvimento das MMPs na comunicação intercelular durante a resposta inflamatória pode tanto estimular quanto deprimir o sistema imune. A compreensão das conseqüências biológicas da atividade das MMPs é crítica na instituição de uma possível terapia por meio de seus inibidores, já que em certos casos a atividade das MMPs pode agravar a condição patológica, enquanto que em outros pode beneficiar o hospedeiro.

Embora nossos achados com relação ao aumento significativo da expressão de MMP-9 nos períodos iniciais da doença periodontal inflamatória induzida sejam importantes e corroborem aqueles descritos na literatura, estes devem ser interpretados com cuidado. A utilização da RTPCR, no presente estudo, nos forneceu a informação de que naquele ambiente estudado havia mensagem para a produção de determinada proteína, e esta mensagem pôde ser semi-quantitativamente avaliada. Entretanto, como as MMPs são uma grande família de enzimas proteolíticas sintetizadas e secretadas em uma forma inativa (proMMPs), ou seja, ligadas a um pequeno peptídeo de $10 \mathrm{kDa}$ que bloqueia sua função, as mesmas necessitam ser clivadas, expondo seu sítio ativo ligado ao zinco para ativação, que ocorre na presença de citocinas. A regulação de sua ação enzimática reside na conversão de seus precursores latentes (pró-MMPs) em 
suas formas ativas ${ }^{156}$. Por isso, a real participação destas enzimas no curso da doença só pode ser avaliada por meio da detecção de sua ativação, o que implicaria na utilização de metodologias complementares. A zimografia, por exemplo, é um teste utilizado com a finalidade de se estabelecer a atividade de uma determinada enzima contida em uma amostra, a partir de uma simples reação enzima-substrato em um gel de eletroforese. Quando a enzima estudada está ativa, ela se concentra em uma banda, de acordo com seu peso molecular específico, e degrada a gelatina presente nesta região do gel. Então, a partir da coloração do gel, esta banda pode ser quantificada. Portanto, o ideal seria a utilização de técnicas de RT-PCR, para detectar a mensagem para a codificação das enzimas, de imuno-histoquímica, que localizaria as células e/ou tecidos expressando as proteínas em questão e, por fim a zimografia, que revelaria se a proteína está ou não ativa. Além disso, as proteínas produzidas no ambiente inflamatório podem ser inativadas por várias proteases abundantes no fluido e nos tecidos gengivais, sendo que a detecção de seus RNAm podem fornecer informações imparciais com relação às MMPs e seus inibidores presentes in vivo ${ }^{116}$.

O reconhecimento da necessidade de se restaurar o equilíbrio natural entre as enzimas destruidoras do tecido conjuntivo e seus inibidores levam ao desenvolvimento de estratégias de tratamento focadas, principalmente, na modulação das MMPs envolvidas na resposta do hospedeiro. Desta forma, a administração de inibidores sintéticos de MMPs restauraria o equilíbrio enzima-inibidor em casos de doença periodontal inflamatória179, 188. A relativa abundância das pró-formas latentes de MMPs comparadas com suas formas ativas na doença periodontal inflamatória precisa ser determinada, assim como o caminho pelo qual as bactérias modulam as interações entre células do hospedeiro e sua matriz extracelular a fim de facilitar sua invasão. 


\section{5- iNOS na doença periodontal inflamatória experimental}

Muitos outros fatores também podem contribuir para a destruição tecidual presente na doença periodontal inflamatória; entre eles, o NO tem se destacado. Até o presente, há muita controvérsia sobre as funções e atividades biológicas deste gás. Por um lado, considerando-se o NO como um radical altamente reativo, ele participa dos mecanismos de defesa inespecíficos naturais da cavidade bucal, prevenindo o crescimento exagerado de bactérias, ou ainda tem papel na manutenção da integridade da mucosa bucal e da homeostase, devido ao seu potencial protetor contra carcinógenos, com quem forma complexos não tóxicos ${ }^{26,27}$. Por outro lado, o NO apresenta citotoxicidade contra várias células, além de atuar como um mediador inflamatório, interagindo com citocinas pró-inflamatórias ${ }^{84,}$ 104, 155, 177.

Enquanto alguns autores relatam o aumento da síntese de NO na doença periodontal inflamatória, outros afirmam o contrário. LOHINAI et al. ${ }^{130}$, em 1998, por meio de imuno-histoquímica, observou, em ratos, imunopositividade para iNOS principalmente em macrófagos, mastócitos, plasmócitos, linfócitos e PMNs, bem como na camada basal do revestimento epitelial gengival. MATEJKA et al. ${ }^{141}$, em 1998, mostraram um aumento das concentrações de L-arginina e L-citrulina em tecidos gengivais de pacientes com doença periodontal inflamatória, sugerindo um aumento da síntese de NO, assim como KENDALL et al. ${ }^{102}$, em 2000, que foram os primeiros a demonstrar a presença de iNOS em doença periodontal inflamatória humana. Em concordância, DI PAOLA et al. ${ }^{49}$, em 2004, observaram um aumento significativo da presença e atividade de iNOS em doença periodontal inflamatória causada por ligadura em ratos. Por outro lado, existem estudos que sugerem a supressão da produção e bioatividade do NO por PMNs neutrófilos presentes em bolsas periodontais de pacientes com doença periodontal inflamatória, especialmente em casos mais severos, assim 
como a maior síntese de NO por PMNs na saliva de pacientes saudáveis comparados com aqueles com gengivite ou periodontite. Isto sugere que um aumento na inflamação ou na destruição tecidual leva a mecanismos incompletamente compreendidos que resultam em aberrações no metabolismo de $\mathrm{NO}^{12}$.

$\mathrm{Na}$ tentativa de se identificar a presença da iNOS na doença periodontal inflamatória induzida propusemo-nos a analisar, a partir de um modelo bem estabelecido de indução da doença em ratos, a expressão de RNAm codificador de iNOS em diferentes períodos de sua evolução. No presente trabalho, ao se comparar a expressão relativa de RNAm de iNOS com relação à expressão de $\beta$-actina, observou-se diferença estatisticamente significativa entre os tecidos gengivais controle e aqueles atingidos pela doença periodontal no período de 3 dias $(P=0,036)$, assim como entre tecidos afetados pela doença periodontal nos períodos de 3 e 7 dias $(P=$ 0,027), indicando a importante expressão desta enzima aos 3 dias após a indução experimental da doença periodontal. Nossos resultados estão de acordo com outros autores que também encontraram um sugestivo aumento na produção de NO nos períodos iniciais da doença periodontal inflamatória experimental, especialmente ao redor do 8o dia após a indução49, 130 .

Apesar de não ter sido possível a análise das concentrações de $\mathrm{NO}$, bem como dos tipos celulares produtores deste gás, acreditamos que a expressão de iNOS encontrada em nosso trabalho possa refletir um importante papel do NO na regulação e, possivelmente, ativação da reabsorção óssea alveolar, já que no período de 3 dias de indução observamos grande perda óssea caracterizada pela presença de inúmeros clastos sobre a superfície óssea, especialmente das regiões mesial e de furca. Ainda, o equilíbrio de citocinas presentes em cada fase da doença periodontal inflamatória, seja ela mais ou menos destrutiva, pode direcionar o papel do NO para uma função imunorreguladora, antimicrobiana ou destrutiva ${ }^{17}$. 
Segundo BATISTA et al.18, em 2002, o aumento do número de células iNOS $^{+}$na doença periodontal inflamatória humana com relação a tecidos saudáveis, aliado ao fato de que estas células eram predominantemente PMNs, sugerem que os PMNs não sejam apenas componentes imunes de defesa inatos e específicos, por meio da produção de enzimas, citocinas e fatores de crescimento, mas que provavelmente estejam envolvidos na patogênese da doença periodontal via produção de NO. Extrapolando esses achados para aqueles encontrados no presente trabalho, sugerimos que a exuberante presença de PMNs nos tecidos afetados pela doença periodontal inflamatória, especialmente nos períodos inicias, possa estar relacionada com a importante expressão de RNAm para iNOS e MMP-9 encontrado no período de 3 dias após a indução. Assim, os neutrófilos podem ter grande participação na ativação da síntese de MMPs via produção de iNOS. Sabe-se que a produção de iNOS potencializa a atividade das MMPs em condrócitos 151 , 216, 220, apesar de o NO possuir efeito modulador da expressão e atividade de MMP-2 e -9 induzidas por citocinas ${ }^{53,54}$, e que a citotoxicidade mediada por NO provavelmente ocorre em associação com sua capacidade de ativar MMPs liberadas principalmente por macrófagos, PMNs e fibroblastos residentes ativados ${ }^{103,114}$.

Em ambientes de intensa e duradoura inflamação, como a doença periodontal inflamatória, há diversas citocinas capazes de estimular a reabsorção óssea ${ }^{8,233}$ e simultaneamente induzir o aumento da produção de NO que, por sua vez, em altas concentrações, é capaz de inibir a reabsorção óssea in vitro ${ }^{36}, 134,178$. Ao estudar a aplicação local de isosorbida, uma substância doadora de NO, na doença periodontal inflamatória experimentalmente induzida por ligadura em ratos, LEITÃO et al. ${ }^{122}$, em 2004, verificaram uma diminuição da reabsorção óssea no grupo de animais submetido a este tratamento, sugerindo um possível efeito anti-inflamatório da isosorbida, ou ainda a capacidade de indução de apoptose de osteoclastos pelo NO. Infelizmente, não é a inibição da reabsorção óssea que observamos 
durante a progressão da doença periodontal inflamatória, embora a doença apresente fases de remissão alternadas por períodos de intensa destruição tecidual. De qualquer forma, sabe-se que o efeito do NO é dependente de sua concentração e isso constitui um paradoxo no estudo da biologia do tecido ósseo, permanecendo, até o presente, sem resposta. Talvez, o NO participe de um mecanismo de feedback negativo nos processos de reabsorção óssea, ao atingir altas concentrações. Ainda, deve-se considerar a capacidade do NO em se difundir de suas células de origem bem como sua breve meia-vida de apenas segundos e rápida reação com o oxigênio, que impedem que altas concentrações sejam atingidas in vivo nas adjacências do sítio de produção. Isto é o que parece ocorrer na doença periodontal inflamatória, com difusão de NO pelo periodonto e fluido sulcular, resultando, preferencialmente, na ativação de células clásticas à sua inibição, ou ainda na alternância de ambos os fenômenos de acordo com uma maior ou menor concentração de NO produzido $^{17}$.

Os efeitos do excesso de NO no tecido mucogengival podem, ainda, contribuir para o desenvolvimento dos sinais clínicos mais freqüentemente encontrados na doença periodontal inflamatória humana. A vermelhidão gengival pode ser explicada, em parte, pelo efeito vasodilatador do NO, assim como o inchaço pelo seu efeito no aumento da permeabilidade vascular. O efeito inibidor do NO na agregação e adesão plaquetárias pode, ainda, colaborar para a crescente tendência dos tecidos moles ao sangramento durante leve sondagem ${ }^{130,149}$. 


\section{6- Presença de mastócitos na doença periodontal inflamatória experimental}

Em nosso estudo, observamos um elevado erro casual interexaminadores durante as comparações estatísticas quanto à contagem de mastócitos. Vários fatores podem ter interferido para este erro. Primeiramente, com relação à técnica de identificação de mastócitos, tanto a utilização de AT quanto de imuno-histoquímica são confiáveis, porém esta é sabidamente mais específica do que a primeira, resultando em contagens facilitadas, mais rápidas e precisas ${ }^{87}$. Infelizmente, não existem no mercado anticorpos anti-triptase de mastócitos para tecidos murinos. Em nossas amostras, a coloração púrpura dos grânulos marcados pelo AT apresentou-se ora condensada no interior dos mastócitos ora dispersa no interior e ao redor das células, dificultando a análise e conferindo-lhe relativa subjetividade, visto que o mastócito é uma célula que possui morfologia bastante variável. O procedimento padrão de coloração metacromática pode, ainda, marcar outras células, como macrófagos e fibroblastos, devido à fagocitose dos grânulos liberados pelos mastócitos, bem como pode deixar de evidenciar mastócitos imaturos 9 .

Um segundo fator que pode ter contribuído para a falta de concordância inter-examinadores foi a realização de contagens em regiões diferentes (1, 2 e 3 ) de um mesmo tecido, de tamanho pequeno, a fim de detalhar a localização dos mastócitos, resultando em contagens discrepantes. Por esta razão, utilizamos os valores médios entre os três examinadores para a análise estatística descritiva, que se resumiu a uma comparação geral entre tecidos controle e doentes, utilizando-se as médias dos valores obtidos para cada região (1, 2 e 3; lados vestibular e lingual) independente do período de indução da doença, seguida pelo teste não paramétrico de Wilcoxon, quando se constatou diferença estatisticamente significativa entre os tecidos controle 
e doentes somente com relação à região 1 , tanto do lado vestibular quanto lingual.

De acordo com nossos resultados, o número de mastócitos $/ \mathrm{mm}^{2}$ na região adjacente aos epitélios sulcular e juncional, bem como na área de inserção conjuntiva (região 1), está diminuído na doença periodontal inflamatória experimentalmente induzida em ratos, com relação aos tecidos gengivais saudáveis, tanto no lado vestibular $(9,85 \pm 9,09$ e 24,07 \pm $24,21$, respectivamente; $P=0,019)$ quanto no lingual $(5,10 \pm 5,17$ e $15,20 \pm$ $14,76$, respectivamente; $P=0,004)$.

Os mastócitos são células residentes do tecido conjuntivo que aumentam numericamente em processos inflamatórios crônicos da cavidade bucal ${ }^{19,} 185$ e contêm uma variedade de moléculas com potencial de mediar a destruição da matriz extracelular característico da doença periodontal inflamatória. Suas proteases (triptase e quimase) clivam fibrinogênio, ativam colagenases latentes, MMP-2129, MMP-380 e MMP-956, degradam a membrana basal $^{147}$, atraem quimicamente PMNs ${ }^{86}$ e estimulam a proliferação celular epitelial ${ }^{31}$. Ainda, em condições inflamatórias os mastócitos residem próximos às células $\mathrm{T}^{144}$, fagocitam e processam antígenos, são capazes de iniciar respostas imunes adquiridas através da apresentação antigênica para células $\mathrm{T}^{60,137}$, e ainda são fonte de citocinas indutoras da resposta imune Th1 e Th2 $140,170,204$.

Tendo em vista esta grande variedade de mediadores oriundos dos mastócitos, a íntima associação funcional entre mastócitos e linfócitos ativados ${ }^{21}, 144$ e a riqueza destes no infiltrado inflamatório da doença periodontal inflamatória humana, acreditávamos que, na doença experimentalmente induzida por ligadura em ratos, a quantidade de mastócitos aumentasse conforme sua evolução, relacionando-se com a gravidade da doença. Além do mais, em estudo recente ${ }^{19}$, encontramos um aumento do número de mastócitos em casos de doença periodontal inflamatória humana com relação a tecidos gengivais clinicamente saudáveis. 
Neste estudo, os mastócitos foram intensamente imunomarcados pela triptase e encontravam-se difusamente distribuídos em íntima proximidade com células semelhantes a plasmócitos e linfócitos. Em concordância, MYINT et al. ${ }^{152}$, em 2002, encontraram números elevados de mastócitos em lesões periodontais humanas. A partir de então, este aumento in vivo do número de mastócitos nos chamou atenção com relação à possível participação destas células nos mecanismos de defesa e nos eventos destrutivos, tanto como células efetoras e responsivas durante a inflamação crônica, quanto uma possível relação funcional entre mastócitos e populações celulares imunocompetentes nas lesões periodontais.

Mais recentemente, NAESSE et al. ${ }^{153}$, em 2003, encontraram mastócitos gengivais humanos expressando fortemente MMPs-1, -2 e -8. STEINSVOLL et al.217, em 2004, sugerem ainda que os mastócitos são importantes em todas as fases evolutivas da doença periodontal inflamatória, desde sua participação como barreira contra a entrada de microrganismos, especialmente pela sua localização intra e subepitelial, bem como na imunorregulação, participando na ativação de linfócitos, na cronificação da lesão ou ainda no processo de reparo tecidual. No entanto, no presente estudo experimental, observamos uma diminuição do número de mastócitos na lesão periodontal de ratos. Além disso, os mastócitos presentes na lesão induzida não se encontravam predominantemente nas áreas ricas em infiltrado inflamatório, sugerindo que, pelo menos em ratos, os mastócitos não parecem ser fonte importante de mediadores ativadores das células inflamatórias, e que possuem uma participação restrita ou ainda ausente nos eventos inflamatórios da doença periodontal. Todavia, como já discutido anteriormente, a metodologia experimental utilizada no presente estudo não nos permitiu a verificação de um infiltrado inflamatório crônico organizado focalmente. Sendo assim, só podemos inferir, quanto à ausência ou limitação da participação dos mastócitos, em relação ao processo inicial agudo da doença periodontal inflamatória induzida em ratos. 
Apesar de contrários à nossa idéia inicial, os resultados do presente estudo estão de acordo com GEMMELL et al.70, em 2004, que encontraram número menor de mastócitos triptase-positivos em tecidos humanos com doença periodontal inflamatória comparados com tecidos saudáveis ou lesões de gengivite. A partir destes resultados, os autores sugeriram que os mastócitos não são fonte de citocinas Th2, predominantes em lesões periodontais.

Alguns autores citam o NO como um modulador endógeno negativo da reatividade dos mastócitos, ao observar sua ativação após inibição da síntese de $\mathrm{NO}^{115,180}$. De acordo com nossos resultados, a presença de uma expressão significativa de iNOS no período de 3 dias após a indução experimental da doença periodontal inflamatória, pode ter colaborado para a pequena quantidade de mastócitos encontrada nos tecidos doentes. Ainda, podemos sugerir que provavelmente os produtos da degranulação dos mastócitos não foram importantes no recrutamento dos inúmeros PMNs observados, e que também não são fonte significante de iNOS e MMP-9, principalmente presentes nos períodos iniciais da doença, indicando que outros mecanismos e tipos celulares estejam envolvidos na migração dos PMNs e na produção de NO e MMP-9 na doença periodontal inflamatória experimentalmente induzida em ratos.

A dúvida sobre a real participação dos mastócitos na iniciação e evolução da doença periodontal inflamatória permanece e, atualmente, muitos trabalhos envolvendo estas células sugerem que suas funções nas doenças inflamatórias crônicas devam ser repensadas. 


\section{6- CONCLUSÕES}

$\sqrt{ } \mathrm{O}$ presente trabalho apresentou uma metodologia bem documentada e plenamente reprodutível de indução experimental da doença periodontal inflamatória em ratos, produzindo lesões inflamatórias com predomínio de PMNs e áreas de reabsorção óssea alveolar desde as primeiras 24 horas após a indução, porém sem progressão para um infiltrado inflamatório linfoplasmocitário organizado focalmente que caracteriza a doença humana;

$\sqrt{ }$ A exuberante presença de PMNs nos tecidos afetados pela doença periodontal inflamatória induzida, especialmente nos períodos inicias, pode estar relacionada com a expressão significativa de RNAm para iNOS e MMP-9 encontrada no período de 3 dias de indução. Assim, os neutrófilos podem ter grande participação na ativação da síntese de MMPs via produção de iNOS, nos períodos iniciais após a indução experimental. Ambas as enzimas podem, então, ter participação importante na destruição tecidual e perda óssea alveolar observadas, tanto direta quanto indiretamente, através da modulação da produção de outros mediadores pró-inflamatórios;

$\sqrt{ }$ Com relação aos mastócitos, os produtos de sua degranulação parecem não ter sido importantes no recrutamento dos inúmeros PMNs observados. Ainda, provavelmente os mastócitos também não sejam fonte significativa de iNOS e MMP-9, presentes nos períodos iniciais da doença, indicando que outros mecanismos e tipos celulares estejam envolvidos na migração dos PMNs e na produção de NO e MMP-9 na doença periodontal inflamatória experimentalmente induzida em ratos. 


\section{7- ANEXOS}




\section{8- REFERÊNCIAS BIBLIOGRÁFICAS}

1. ACHONG, R. et al. Membrane type (MT) 1-matrix metalloproteinase (MMP) and MMP-2 expression in ligature-induced periodontitis in the rat. $\mathbf{J}$ Periodontol, v.74, n.4, p.494-500, Apr. 2003.

2. ADAMS, R.A.; ZANDER, H.A.; POLSON, A.M. Cell populations in transseptal fiber region before, during and after experimental periodontitis in squirrel monkeys. J Periodontol, v.49, n.1, p.7-12, Jan. 1979.

3. ALEXANDER, M.B.; DAMOULIS, P.D. The role of cytokines in the pathogenesis of periodontal disease. Curr Opin Periodontol, v.1, p.39-53, 1994.

4. AMERICAN ACADEMY OF PERIODONTOLOGY. 1999 International Workshop for a classification of periodontal diseases and conditions. Annals Periodontol, v.4, n.1, p.7-37, Dec. 1999.

5. AMSTAD-JOSSI, M.; SCHROEDER, H.E. Age-related alterations of periodontal structures around the cemento-enamel junction and of the gingival connective tissue composition in germ-free rats. J Periodontal Res, v.13, n.1, p.76-90, Jan. 1978.

6. ARMITAGE, G.C. Development of a classification system for periodontal disease and conditions. Ann Periodontol, v.4, n.1, p.1-19, Dec. 1999.

7. ASARO, J.P. et al. Experimental periodontal disease. Immediate Hypersensitivity. J Periodontol, v.54, n.1, p.23-8, Jan. 1983.

8. ASSUMA, R. et al. IL-1 e TNF antagonists inhibit the inflammatory response and bone loss in experimental periodontitis. J Immunol, v.160, n.1, p.403-9, Jan. 1998.

9. ATKINS, F.M. et al. Interactions between mast cells, fibroblasts and connective tissue components. Int Arch Allergy App1 Immunol, v.77, n. 1-2, p.96-102, 1985.

**Normas recomendadas para uso no âmbito da Universidade de São Paulo, com base no documento "Referências Bibliográficas: exemplos", emanados do Conselho Supervisor do Sistema Integrado de Bibliotecas da USP, em reunião de 20 de setembro de 1990. 
10. ATTSTRON, R. Studies on neutrophil polymorphonuclear leukocytes at the dentogingival junction in gingival health and disease. J Periodont Res, v.8, p.1-15, xxx 1971. Supplement 8.

11. AURÉlio, A.B.H. Novo Dicionário da Língua Portuguesa. 2.ed. Rio de Janeiro, Nova Fronteira, 1986.

12. AURER, A. et al. Nitric oxide is decreased in periodontitis. J Clin Periodontol, v.28, n.6, p.565-8, June 2001.

13. BAER, P.N.; LIEBERMAN, J.E. Periodontal disease in six stains of inbred mice. J Dent Res, v.39, n.2, p.215-25, Mar. - Apr. 1960.

14. BARAM, D. et al. Human mast cells release metalloproteinase-9 on contact with activated T cells: juxtacrine regulation by TNF- $\alpha$. J Immunol, v.167, n.7, p.4008-19, Oct. 2001.

15. BARNETT, M.L. The fine structure of human epithelial mast cells in periodontal disease. J Periodont Res, v.8, n.6, p.371-80, Nov. - Dec. 1973.

16. BARNETT, M.L. The fine structure of human connective tissue mast cells in periodontal disease. J Periodont Res, v.9, n.2, p.84-91, Mar.-Apr. 1974.

17. BATISTA, A.C. Avaliação da expressão da enzima óxido nítrico-sintase induzível (iNOS) em gengivites associadas à placa dentobacteriana e periodontites crônicas localizadas. Bauru, 2001. 90p. Dissertação (Mestrado) - Faculdade de Odontologia de Bauru, Universidade de São Paulo.

18. BATISTA, AC. et al. Nitric oxide synthesis and severity of human periodontal disease. Oral Dis, v.8, n.5, p.254-60, Sept. 2002.

19. BATISTA, A.C.; RODINI, C.O.; LARA, V.S. Quantification of mast cells in different stages of human periodontal disease. Oral Dis, 2005. / no prelo/

20. BELTING, C.M. et al. Age changes in the periodontal tissues of the rat molar. J Dent Res, v.32, n.3, p.332-53, June 1953.

21. BHATTACHARYYA, S.P. et al. Activated T lymphocytes induce degranulation and cytokine production by human mast cells following cell-to-cell contact. J Leukoc Biol, v.63, n.3, p.337-41, Mar. 1998.

22. BIRKEDAL-HANSEN, H. et al. Activation of keratinocyte-mediated collagen (type I) breakdown by suspect human periodontopathogen: evidence for a 
novel mechanism of connective tissue breakdown. J Periodont Res, v.19, n.6, p.645-50, Nov. 1984.

23. BIRKEDAL-HANSEN, H. Role of matrix metalloproteinases in human periodontal diseases. J Periodontol, v.64, n.5, p.474-84, May 1993. Supplement.

24. BIRKEDAL-HANSEN, H. Role of cytokines and inflammatory mediators in tissue destruction. J Periodont Res, v.28, n.6, p.500-10, Nov. 1993.

25. BJÖRNSSON, M.J. et al. Influence of the matrix metalloproteinase inhibitor batimastat (BB-94) on periodontal bone destruction in Sprague-Dawley rats. J Periodont Res, v.39, n.4, p.269-74, Aug. 2004.

26. BODIS, S.; HAREGEWOIN, A. Evidence for the release and possible neural regulation of nitric oxide in human saliva. Biochem Biophys Res Comm, v.194, n.1, p.347-50, July 1993.

27. BODIS, S.; HAREGEWOIN, S. Significantly reduced salivary nitric oxide levels in smokers. Ann Oncol, v.5, n.4, p.371-2, Apr. 1994.

28. BOUDREAU, N.; BISSEL, M.J. Extracellular matrix signaling: integration of form and function in normal and malignant cells. Curr Opin Cell Biol, v.10, n.5, p.640-6, Oct. 1998.

29. BRANDTZAEG, P.; KRAUS, F.W. Autoimmunity and periodontal disease. Odontol Tidskr, v.73, p.285-393, June 1965.

30. BRENNAN, P.A.; THOMAS, G.J.; LANGDON, J.D. The role of nitric oxide in oral diseases. Archs Oral Biol, v.48, n.2, p.93-100, Feb. 2003.

31. CAIRNS, J.A..; WALLS, A.F. Mast cell tryptase is a mitogen for epithelial cells. Stimulation of IL-8 production and intercellular adhesion molecule-1 expression. J Immunol, v.156, n.1, p.275-83, Jan. 1996.

32. CAROSSA, S. et al. Oral nitric oxide during plaque deposition. Eur J Clin Invest, v.31, n.10, p.876-9, Oct. 2001.

33. CARRANZA, F.A.J.; CABRINI, R.L. Mast cells in human gingiva. Oral Surg, v.8, n.10, p.1093-9, Oct. 1955.

34. CAWSON, R.A.; BINNIE, W.H.; EVESON, J.W. Atlas Colorido de enfermidades da boca. Correlações clínicas e patológicas. 2.ed. Artes Médicas, São Paulo, 1997. 
35. CESAR NETO, J.B. et al. Matrix metalloproteinase-2 may be involved with increased bone loss associated with experimental periodontitis and smoking: a study in rats. J Periodontol, v. 75, n.7, p. 995-1000, Jul 2004.

36. CHAE, H.J. et al. Nitric Oxide is a regulator of bone remodelling. J Pharm Pharmacol, v.49, n.9, p.897- 902, Sept. 1997.

37. CHANG, Y.C. et al. Regulation of matrix metalloproteinase production by cytokines, pharmacological agents and periodontal pathogens in human periodontal ligament fibroblast cultures. J Periodont Res, v.37, n.3, p.196203, June 2002.

38. CHO, M.; GARANT, P.R. Development and general structure of the periodontium. Periodontol 2000, v.24, n.1, p.9-27, Oct. 2000.

39. CHOMCZYNSKI, P.; SACCHI, N. Single-step method of RNA isolation by acid guanidinium thiocyanate-phenol-chloroform extraction. Anal Biochem, v.162, n.1, p.156-9, Apr. 1987.

40. COESTERTON, J.W. et al. Bacterial biofilms in nature and disease. Annu Rev Microbiol, v.41, p.435-64, Oct. 1987.

41. COLE, K.C.; SEYMOUR, G.J.; POWELL, R.N. Phenotypic and functional analysis of $\mathrm{T}$ cells extracted from chronically inflamed human periodontal tissues. J Periodontol, n.58, n.8, p.569-73, Aug. 1987.

42. COROTTI, M. V. Avaliação imuno-histoquímica das MMPs $-\mathbf{2}$ e $\mathbf{- 9}$ na evolução de lesões periapicais induzidas em dentes molares de ratos. Bauru, 2005. 63p. Dissertação (Mestrado) - Faculdade de Odontologia de Bauru, Universidade de São Paulo.

43. DAGHIGH, F. et al. Human gingival fibroblasts produce nitric oxide in response to proinflammatory cytokines. J Periodontol, v.73, n.4, p.392-400, Apr. 2002.

44. DAHAN, M. et al. Expression of matrix metalloproteinases in healthy and diseased human gingiva. J Clin Periodontol, v.28, n.2, p.128-36, Feb. 2001.

45. DALAISSÉ, J-M. et al. Proteinases in bone resorption: obvious and less obvious roles. Clin Chim Acta, v.291, n.2, p.223-34, Feb. 2000.

46. DE PATER-HUIJSEN, F.L. et al. Products from mast cells influence $\mathrm{T}$ lymphocyte proliferation and cytokine production- relevant to allergic 
asthma? Immunol Lett, v.57, n.1-3, p.47-51, June 1997.

47. DE PATER-HUIJSEN, F.L. et al. Products from human mast cell line cells enhance the production of interferon-gamma by $\mathrm{CD}^{+}$and $\mathrm{CD}^{+} \mathrm{T}$ cells. Immunol, v.106, n.1, p.11-9, May 2002.

48. DE SOUZA, A.P. et al. Analysis of the MMP-9 (C-1562T) and TIMP-2 (G-418C) gene promoter polymorphisms in patients with chronic periodontitis. J Clin Periodontol, v.32, n.2, p.207-11, Feb. 2005.

49. DI PAOLA, R. et al. Effect of aminoguanidine in ligature-induced periodontitis in rats. J Dent Res, v.83, n.4, p.343-8, Apr. 2004.

50. DUMITRESCU, A.L. et al. A model of periodontitis in the rat: effect of lipopolysaccharide on bone resorption, osteoclast activity, and local peptidergic innervation. J Clin Periodontol, v.31, n.8, p.596-603, Aug. 2004.

51. DZINK, J.L. et al. Gram negative associated species with active destructive periodontal lesions. J Clin Periodontol, v.12, n.8, p.648-59, Sept. 1985.

52. DZINK, J.L.; SOCRANSKY, S.S.; HAFFAJEE. The predominant cultivable microbiota of active and inactive periodontal lesions. J Clin Periodontol, v.15, n.5, p.316-23, May 1988.

53. EAGLETON, M.J. et al. Nitric oxide inhibition increases aortic wall matrix metalloproteinase-9 expression. J Surg Res, v.104, n.1, p.15-21, May 2002.

54. EBERHARDT, $W$. et al. Nitric oxide modulates expression of matrix metalloproteinase-9 in rat mesangial cells. Kyd Int, v.57, n.1, p.59-69, Jan. 2000.

55. EJEIL, A.L. et al. Expression of matrix metalloproteinases (MMPs) and tissue inhibitors of metalloproteinases (TIMPs) in healthy and diseased human gingiva. J Periodontol, v.74, n.2, p.188-95, Feb. 2003.

56. FANG, K.C. et al. Dog mast cell alpha-chymase activates progelatinase B by cleaving the Phe88-Gln89 and Phe91-Glu92 bonds of the catalytic domain. J Biol Chem, v.272, n.41, p.25628-35, Oct. 1997.

57. FARRIS, E.J. The rat in laboratory investigation. New York, Hafner, 1949.

58. FIEHN, N.E.; KLAUSEN, B.; EVANS, R.T. Periodontal bone loss in Porphyromonas gingivalis-infected specific pathogen-free rats after preinoculation with endogenous Streptococcus sanguis. J Periodont Res, v. 
27, n.6, p.609-14, Nov. 1992.

59. FLEMMIG, T.F. Periodontitis. Ann Periodontol, v.4, n.1, p.32-7, Dec. 1999.

60. FOX, C.C.; JEWEL, S.D.; WHITACRE, C.C. Rat peritoneal mast cells present antigen to a PPD-specific T cell line. Cell Immunol, v.158, n.1, p.253-8, Oct. 1994.

61. FRAME, B.; NIXON, R.K. Bone-marrow mast cells in osteoporosis of aging. $\mathbf{N}$ Engl J Med, v.279, n.12, p.626-30, Sept. 1968.

62. FRAVALO, P.; MÉNARD, C.; BONNAURE-MALLET, M. Effect of Porphyromonas gingivalis on epithelial cell MMP-9 type-IV collagenase production. Infect Immun, v.64, n.12, p.4940-5, Dec. 1996.

63. FREEMAN, E. Periodonto. In: TEN CATE, A.R. Histologia Bucal: Desenvolvimento, Estrutura e Função. 5.ed. Rio de Janeiro, Guanabara Koogan S.A., 2001. Cap.13, p.238-71.

64. FULLMER, H.; GIBSON, W. Collagenolytic activity of gingivae of man. Nature, v.209, n.24, p.728-9, Feb. 1966.

65. GALBRAITH, G.M. et al. Tumor necrosis factor alpha production by oral leucocytes: influence of tumor necrosis factor genotype. J Periodontol, v.69, n.4, p.428-33, Apr. 1998.

66. GALLI, S.J. New concepts about the mast cell. N. Engl J Med, v.328, n.4, p.25765, Jan. 1993.

67. GARANT, P.R.; CHO, M.I. Histopathogenesis of spontaneous periodontal disease in conventional rats. I. Histometric and histologic study. J Periodont Res, v.14, n.4, p.297-309, July 1979.

68. GARANT, P.R.; PAIK, K-S.; CHO, M-I. The distribution of plasma cells in naturally occurring periodontitis lesions in rats. A light and electron microscopy study. J Periodontol, v.54, n.4, p.227-35, Apr. 1983.

69. GEMMEL, E.; YAMAZAKI, K.; SEYMOUR, G.J. Destructive periodontitis lesions are determined by the nature of the lymphocyte response. Crit Rev Oral Biol Med, v.13, n.1, p.17-34, Jan. 2002.

70. GEMMELL, E.; CARTER, C.L.; SEYMOUR, G.J. Mast cells in human periodontal disease. J Dent Res, v.83, n.5, p.387-7, May 2004.

71. GENCO, R.J. Host response in periodontal diseases: current concepts. J 
Periodontol, v.63, n.4, p.338-55, Apr. 1992. Supplement.

72. GILHUUS-MÖE, O.; KVAM, E. Behaviour of epithelial remnants of Malassez following experimental movement of rat molars. Acta Odontol Scand, v.30, n.2, p.139-49, May 1972.

73. GOLDHABER, P. Heparin enhancement of factors stimulating bone resorption in tissue culture. Science v.147, n.3656, p. 407-8, Jan. 1965.

74. GOLUB, L. et al. Further evidence that tetracyclines inhibit collagenase activity in human crevicular fluid and from other mammalian sources. J Periodont Res, v.20, n.1, p.12-23, Jan. 1985.

75. GOLUB, L.M. et al. Low dose doxycycline therapy: effect on gingival and crevicular fluid collagenase activity in humans. J Periodont Res, v.25, n.6, p.321-30, Nov. 1990.

76. GOLUB, L. et al. A non-antimicrobial tetracycline inhibits gingival matrix metalloproteinases and bone loss in Porphyromonas gingivalis-induced periodontitis in rats. Ann N Y Acad Sci, v.732, p.96-111, Sept. 1994.

77. GOLUB, L.M. et al. Doxycycline inhibits neutrophil (PMN)-type matrix metalloproteinases in human adult periodontitis gingiva. J Clin Periodontol, v.22, n.2, p.100-9, Feb. 1995.

78. GORDON, J.R.; BURD, P.R.; GALLI, S.J. Mast cells as a source of multifunctional cytokines. Immunol Today, v.11, p.458-64, 1990.

79. GORE, E.A. et al. Interleukin-1beta+3953 allele 2: association with disease status in adult periodontitis. J Clin Periodontol, v.25, n.10, p.781-85, Oct. 1998.

80. GRUBER, B.L. et al. Synovial procollagenase activation by human mast cell tryptase dependence upon matrix metalloproteinase 3 activation. J Clin Invest, v.84, n.5, p.1657-62, Nov. 1989.

81. GÜNHAN, M. et al. Mast cells in periodontal disease. Ann Dent, v.50, n.1, p.25-9, Summer, 1991.

82. GYÖRFI, A. et al. Neurogenic component in ligature-induced periodontitis in the rat. J Clin Periodontol, v.21, n.9, p.601-5, Oct. 1994.

83. HAFFAJEE, A.D., SOCRANSKY, S.S. Microbial etiological agents of destructive periodontal diseases. Periodontol 2000, v.5, p.78-111, June 1994. 
84. HAMID, Q. et al. Induction of nitric oxide synthase in asthma. Lancet, v.342, n. 8886-7, p.1510-3, Dec. 1993.

85. HARDT, A.B. Bisphosphonate effects on alveolar bone during rat molar drifting. J Dent Res, V.67, N.11, P.1430-3, Nov. 1988.

86. HE, S.; PENG, Q.; WALLS, A.F.Potent induction of a neutrophil and eosinophil-roch infiltrate in vivo by human mast cell tryptase: selective enhancement of eosinophil recruitment by histamine. J Immunol, v.159, p.6216-25, 1997.

87. HEANEY, L.G. et al. A comparison of three standard methods of identifying mast cells in endobronchial biopsies in normal and asthmatic subjects. Allergy, v.52, n.8, p.836-43, Aug. 1997.

88. HEIJL, L.; RIFKIN, B.R.; ZANDER, H.A. Conversion of chronic gingivitis to periodontitis in squirrel monkeys. J Periodontol, v.47, n.12, p.710-6, Dec. 1976.

89. HEIJL, L. et al. Periodontal disease in gnotobiotic rats. J Periodont Res, v.15, n.4, p.405-19, July 1980.

90. HEINO, J. Biology of tumor cell invasion: interplay of cell adhesion and matrix degradation. Int J Cancer, v.65, n.6, p.717-22, Mar. 1996.

91. HIROSE, M. et al. Expression of cytokines and inducible nitric oxide synthase in inflamed gingival tissue. J Periodontol, v.72, n.5, p.590-7, May 2001.

92. HOFFMAN, MM.; SCHOUR, I. Quantitative studies in the development of the rat molar. II. Alveolar bone, cementum and eruption. Am J Orthod, v.26, p.854-74, 1940.

93. HOGG, N. et al. Production of hydroxyl radicals from the simultaneous generation of superoxide and nitric oxide. Biochem J, v.281, pt2, p.419-24, Jan. 1992.

94. HORTON, J.E.; OPPENHEIN, J.J.; MERGENHAGEN, S.E. A role of cell mediated immunity in the pathogenesis of periodontal disease. J Periodontol, v.45, n.5, p.351-60, May 1974.

95. HOUSTON, W.J.B. The analysis of errors in orthodontic measurements. Am J Orthod, v.83, n.5, p.382-90, May 1983.

96. HUTTENLOCHER, A.; SANDBORG, R.R.; HORWITZ, A.F. Adhesion in cell 
migration. Curr Opin Cell Biol, v.7, n.5, p.697-706, Oct. 1995.

97. IRVING, J.T.; SOCRANSKY, S.S.; TANNER, A.C.R. Histological changes in experimental periodontal disease in rats monoinfected with Gram-negative organisms. J Periodont Res, v.13, n.4, p.326-32, July 1978.

98. JEFFCOAT, M.K. et al. Treatment of periodontal disease in beagles with lodoxamide ethyl, an inhibitor of mast cell release. J Periodont Res, v.20, n.5, p.532-41, Sept. 1985.

99. JEFFCOAT, M.K.; REDDY, M.S. Progression of probing attachment loss in adult periodontitis. J Periodontol, n.62, n.3, p.185-9, Mar. 1991.

100. JOTWANI, R.; CUTLER, C.W. Adult periodontitis: specific bacterial infection or chronic inflammation? J Med Microbiol, v.43, n.3, p.187-8, Mar. 1998.

101. KAT, P.S.P. et al. Distribution of the epithelial rests of Malassez and their relationship to blood vessels of the periodontal ligament during rat tooth development. Aut Orthod, v.19, n.2, p.77-86, Nov. 2003.

102. KENDALL, H.K. et al. Nitric oxide synthase type-II is synthesized by human gingival tissue and cultured human gingival fibroblasts. J Periodontal Res, v.35, n.4, p.194-200, Aug. 2000.

103. KENDALL, H.K.; MARSHALL, R.I.; BARTOLD, P.M. Nitric oxide and tissue destruction. Oral Dis, v.7, n.1, p.2-10, Jan. 2001.

104. KHARITONOV, S.A. et al. Increased nitric oxide in exhaled air of asthmatic patients. Lancet, v.343, n.8890, p.133-5, Jan. 1994.

105. KHARITONOV, S.A. et al. Acute and chronic effects of cigarette smoking on exhaled nitric oxide. Am J Resp Crit Care, v.152, n.2, p.609-12, Aug. 1995.

106. KIMURA, S. et al. Induction of experimental periodontitis in mice with Porphyromonas gingivalis-adhered ligatures. J Periodontol, v.71, n.7, p.116773, July 2000.

107. KINANE, D.F. Metalloproteinases in the pathogenesis of periodontal diseases. Curr Opin Dent, v.2, p.25-32, Mar. 1992.

108. KLAUSEN, B. Microbiological and immunological aspects of experimental periodontal disease in rats: a review article. J Periodontol, v.62, n.1, p.59-73, Jan. 1991.

109. KODA, W. et al. Evidence of the participation of peribiliary mast cells in 
regulation of the peribiliary vascular plexus along the intrahepatic biliary tree. Lab Invest, v.80, n.7, p.1007-17, July 2000.

110. KOLENBRANDER, P.E.; LONDON, J. Adhere today, here tomorrow: oral bacterial adherence. J Bacteriol, v.175, n.11, p.3247-52, June 1993.

111. KORNMAN, K.S. et al. The interleukin-1 genotype as a severity factor in adult periodontal disease. J Clin Periodontol, v.24, n.1, p.72-7, Jan. 1997.

112. KORNMAN, K.S.; PAGE, R.C.; TONETTI, M.S. The host response to the microbial challenge in periodontitis: assembling the players. Periodontol 2000, v.14, p.33-53, June 1997.

113. KOROSTOFF, J.M. et al. Analysis of in situ protease activity in chronic adult periodontitis patients: expression of activated MMP-2 and a 40kDa serine protease. J Periodontol, v.71, n.3, p.353-60, Mar. 2000.

114. KRÖNCKE, K.; FEHSEL, K.; KOLB-BACHOFEN, V. Nitric oxide: cytotoxicity versus cytoprotection- how, why, when, and where? Nitric Oxide, v.1, n.2, p.107-20, Jan. 1997

115. KRUBES, P.; GRANGER, D.N. Leukocyte-endothelial cell interactions evoked by mast cells. Cardiovasc Res, v.32, n.4, p.699-708, Oct. 1996.

116. KUBOTA, T. et al. Expression of mRNA for matrix metalloproteinases and tissue inhibitors of metalloproteinases in periodontitis-affected human gingival tissue. Arch Oral Biol, v.41, n.3, p.253-62, Mar. 1996.

117. KUHR, A. et al. Observations on experimental marginal periodontitis in rats. J Periodont Res, v.39, n.2, p.101-6, Apr. 2004.

118. LARIVEE, J.; SODEK, J.; FERRIER, J.M. Collagenase and collagenase inhibitor activities in crevicular fluid of patients receiving treatment for localized juvenile periodontitis. J Periodont Res, v.21, n.6, p.702-15, Nov. 1986.

119. LAURENT, M.; LEPOIVRE, M.; TENU, J-P. Kinetic modeling of the nitric oxide gradient in vitro by adherent cells expressing inducible nitric oxide synthase. Biochem J, v.314, pt.1, p.109-13, Feb. 1996.

120. LEE W. et al. Evidence of a direct relationship between neutrophil collagenase activity and periodontal tissue destruction in vivo: role of active enzyme in human periodontitis. J Periodont Res, v.30, n.1, p.23-33, Jan. 1995.

121. LEHNER, T. et al. Sequential cell mediated immune responses in experimental 
gingivitis in man. Clin Exp Immunol, v.16, n.3, p.481-92, Mar. 1974.

122. LEITÃO, R.F.C. et al. Locally applied isosorbide decreases boné resorption in experimental periodontitis in rats. J Periodontol, v.75, n.9, p.1227-32, Sept. 2004.

123. LINDHE, J.; KARRING, T. Anatomia do periodonto. In: LINDHE, J. Tratado de periodontia clínica e implantologia oral. 3.ed. Rio de Janeiro, Guanabara Koogan, 1999. Cap.1, p.3-42.

124. LISTGARTEN, M.A. Similarity of epithelial relationships in the gingival of rat and man. J Periodontol, v.46, n.11, p.677-80, Nov. 1975.

125. LISTGARTEN, M.A. Pathogenesis of periodontitis. J Clin Periodontol, v.13, n.5, p.418-30, May 1986.

126. LISTGARTEN, M.A. The structure of dental plaque. Periodontol 2000, v.5, p.52-65, June 1994.

127. LIU, F. et al. Expression of inflammatory cytokines and beta-defensin 1 mRNAs in porcine epithelial rests of Malassez in vitro. Med Electron Microsc, v.34, n.3, p.174-8, Sept. 2001

128. LÖE, H.; WAERHAUG, J. Experimental replantation of teeth in dogs and monkeys. Arch Oral Biol, v.3, n.3, p,176-84, Apr. 1961.

129. LOHI, J.; HARVIMA, I.; KESKI-OJA, J. Pericellular substrates of human mast cell tryptase: 72000 dalton gelatinase and fibronectin. J Cell Biochem, v.50, n.4, p.337-49, Dec. 1992.

130. LOHINAI, Z. et al. Protective effects of mercaptoethylguanidine, a selective inhibitor of inducible nitric oxide synthase, in ligature-induced periodontitis in the rat. Brit J Pharmacol, v.123, n.3, p.353-60, Feb. 1998.

131. LOHINAI, Z. et al. Evidence for reactive nitrogen species formation in the gingivomucosal tissue. J Dent Res, v.80, n.2, p.470-5, Feb. 2001.

132. LORSBACH, R.B.; RUSSELL, S.W. A specific sequence of stimulation is required to induce synthesis of the anti-microbial molecule nitric oxide by mouse macrophages. Infect Immun, v.60, n.5, p.2133-5, May 1992.

133. LOVE, K.S. et al. IFN- $\gamma$-stimulated enhancement of MHC class II antigen expression by the human mast cell line HMC-1. Cell Immunol, v.170, n.1, p.85-90, May 1996. 
134. LÖWIK, C.W.G.M. et al. Inducible production of nitric oxide in osteoblast-like cells and in fetal mouse bone explants is associated with suppression of osteoclastic bone resorption. J Clin Invest, v.93, n.4, p.1465-72, Apr. 1994.

135. MACNAUL, K.L. et al. Discoordinate expresion of stromelysin, collagenase, and tissue inhibitor of metalloproteinases-1 in rheumatoid human synovial fibroblast. Synergistic effects of interleukin-1 and tumor necrosis factoralpha on stromelysin expression. J Biol Chem, v.265, n.28, p.17238-45, Oct. 1990.

136. MAKELA, M. et al. Matrix metalloproteinases (MMP-2 and MMP-9) of the oral cavity: cellular origin and relationship to periodontal status. J Dent Res, v.73, n.8, p.1397-406, Aug. 1994.

137. MALAVIYA, R. et al. Mast cells process bacterial Ags through a phagocytic route for class I MHC presentation to T cells. J Immunol, v.156, n.4, p.14906, Feb. 1996.

138. MANCINELLI, R.L.; McKAY, C.P. Effects of nitric oxide and nitrogen on bacterial growth. Appl Environ Microb, v.46, n.1, p.198-202, July 1983.

139. MARCET-PALACIOS, M. et al. Nitric oxide and cyclic GMP increase the expression of matrix metalloproteinase-9 in vascular smooth muscle. $\mathbf{J}$ Pharmacol Exp Ther, v.307, n.1, p.429-36, Oct. 2003.

140. MARIETTA, E.V.; CHEN, Y.; WEIS, J.H. Modulation of expression of the antiinflammatory cytokines interleukin-13 and interleukin-10 by interleukin-3. Eur J Immunol, v.26, n.1, p.49-56, Jan. 1996.

141. MATEJKA, M. et al. Nitric oxide synthesis is increased in periodontal disease. J Periodontol Res, v.33, n.8, p.517-8, Nov. 1998.

142. McCAWLEY, L.J.; MATRISIAN, L.M. Matrix metalloproteinases: they're not just for matrix anymore! Curr Opin Cell Biol, v.13, n.5, p.534-40, Oct. 2001.

143. MEITNER, S. Co-destructive factors of marginal periodontitis and repetitive mechanical injury. J Dent Res, v.54, p.C78-85, Oct. 1975, Special issue C.

144. MEKORI, Y.A.; METCALFE, D.D. Mast cell-T cell interactions. J Allergy Clin Immunol, v.104, n.3, p.517-23, Sept. 1999.

145. METCALFE, D.D.; BARAM, D.; MEKORI, Y.A. Mast cells. Physiol Rev, v.77, n.4, p.1033-79, Oct. 1997. 
146. MILJKOVIC, D.J. et al. Mycophenolic acid inhibits activation of inducible nitric oxide synthase in rodent fibroblasts. Clin Exp Immunol, v.132, n.2, p.23946, May 2003.

147. MIZUTANI, H. et al. Rapid and specific conversion of precursor interleukin 1 beta (IL-1 beta) to an active IL-1 species by human mast cell chymase. J Exp Med, v.174, n.4, p.821-5, Oct. 1991.

148. MOHAN, R. et al. Matrix metalloproteinase gelatinase B (MMP-9) coordinates and effects epithelial regeneration. J Biol Chem, v.277, n.3, p.2065-72, Jan. 2002.

149. MONCADA, S. et al. Nitric oxide: physiology, pathophysiology and pharmacology. Pharmacol Rev, v.43, n.2, p.109-41, June 1992.

150. MONCADA, S.; HIGGS, A. The L-Arginine-Nitric Oxide Pathway. New Engl J Med, v.329, n.27, p.2002-12, Dec. 1993.

151. MURRELL, G.A.; JANG, D.; WILLIAMS, R.J. Nitric oxide activates metalloprotease enzymes in articular cartilage. Biochem Biophys Res Commun, v.206, n.1, p.15-21, Jan. 1995.

152. MYINT, M. et al. Highly increased numbers of leukocytes in inflamed gingival from patients with HIV infection. AIDS, v.16, n.2, p.235-43, Jan. 2002.

153. NAESSE, E.P. et al. Matrix metalloproteinases and their inhibitors in gingival mast cells in persons with and without HIV-infection. J Periodont Res, v.38, n.6, p.575-82, Dec. 2003.

154. NEIDERS, M.E. et al. Bone reaction in experimental periodontitis induced by delayed hypersensitivity. J Periodontol, v.50, n.3, p.140-5, Mar. 1979.

155. NGUYEN, T. et al. DNA damage and mutation in human cells exposed to nitric oxide in vitro. Proc Natl acad Sci USA, v.89, n.7, p.3030-4, Apr. 1992.

156. NGUYEN, M.; ARKELL, J.; JACKSON, J. Human endothelial gelatinases and angiogenesis. Int J Biochem Cell Biol, v.33, n.10, p.960-70, Oct. 2001.

157. NISENGARD, RJ. The role of immunology in periodontal disease. J Periodontol, v.48, n.9, p.505-16, Sept. 1977.

158. NOVAK, M.J. et al. Adjunctive benefits of subantimicrobial dose doxycycline in the management of severe, generalized, chronic periodontitis. J Periodontol, v.73, n.7, p.762-9, July 2002. 
159. NUKI, K.; FARNOUSH, A. The inhibition of mast cell degranulation in monkey gingiva by disodium cromoglycate. J Periodont Res, v.10, n.5, p.282-7, Nov. 1975.

160. NYMAN, S.; SCHROEDER, H.E.; LINDHE, J. Suppression of inflammation and bone resorption by indomethacin during experimental periodontitis in dogs. J Periodontol, v.50, n.9, p.450-61, Sept. 1979.

161. OKADA, H. et al. The function of gingival lymphocytes on the establishment of human periodontitis. Adv Dent Res, v.2, n.2, p.364-67, Nov. 1988.

162. OKAMOTO, $\mathrm{T}$. et al. Activation of human neutrophil procollagenase by nitrogen dioxide and peroxynitrite: a novel mechanism for procollagenase activation involving nitric oxide. Arch Biochem Biophys, v.342, n.2, p.26174, June 1997.

163. OVERALL, C.M.; WIEBKIN, O.W.; THONARD, J.C. Demonstration of tissue collagenase activity in vivo and its relationship to inflammation severity in human gingiva. J Periodont Res, v.22, n.2, p.81-8, Mar. - Apr. 1987.

164. PAGE, R.C.; SCHROEDER, H.E. Pathogenesis of inflammatory periodontal disease. A summary of current work. Lab Invest, v.34, n.3, p.235-49, Mar. 1976.

165. PAGE, R.C.; SCHROEDER, H.E. Structure and pathogenesis. In: Periodontal disease: basic phenomena, clinical management, and occlusal and restorative interrelationships. 2.ed. Philadelphia, Lea \& Febiger, c1990. Cap.7, p.183-220.

166. PAGE, R.C. The role of inflammatory mediators in the pathogenesis of periodontal disease. J Periodontal Res, v.26, n.3, p.230-42, May 1991.

167. PAGE, R.C. et al. Advances in the pathogenesis of periodontitis: summary of developments, clinical implication and future directions. Periodontol 2000, v.14, p.216-48, June 1997.

168. PAGE, R.C. Periodontal diseases: a new paradigm. J Dent Educ, v.62, n.10, p.812-21, Oct. 1998.

169. PAQUETTE, D.W.; WILLIAMS, R.C. Modulation of host inflammatory mediators as a treatment strategy for periodontal diseases. Periodontol, v.24, n.1, p.239-52, Oct. 2000. 
170. PLAUT, M. et al. Mast cell lines produce lymphokines in response to crosslinkage of FC epsilon RI or to calcium ionophores. Nature, v.339, n.6219, p.64-7, May 1989.

171. PÖLLÄNEN, M.T.; SALONEN, J.I.; UITTO, V. Structure and function of the tooth-epithelial interface in health and disease. Periodontol 2000, v.31, n.1, p.12-31, Feb. 2003.

172. POLSON, A.M.; KENNEDY, J.E.; ZANDER, H.A. Trauma and progression of marginal periodontitis in squirrel monkeys: I. Co-destructive factors of periodontitis and thermally-produced injury. J Periodont Res, v.9, n.2, p.100-7, Mar. - Apr. 1974.

173. POLSON, A.M. Trauma and progression of marginal periodontitis in squirrel monkeys: II. Co-destructive factors of periodontitis and mechanicallyproduced injury. J Periodont Res, v.9, n.2, p.108-13, Mar. - Apr. 1974.

174. QU, Z. et al. Mast cells are a major source of basic fibroblastic growth factor in chronic inflammation and cutaneous hemangioma. Am J Pathol, v.147, n.3, p.564-73, Sept. 1995.

175. QU, Z. et al. Synthesis of basic fibroblastic growth factor in murine mast cells. Regulation by transforming growth factor beta, tumor necrosis factor alpha, and stem cell factor. Int Arch Allergy Immunol, v. 115, n.1, p.47-54, Jan. 1998.

176. QU, Z. et al. Ultrastructural immunolocalization of basic fibroblast growth factor in mast cell secretory granules: morphological evidence for bFGF release through degranulation. J Histochem Cytochem, v.46, n.10, p.111928, Oct. 1998.

177. RADOMSKI, M.W.; PALMER, R.M.J.; MONCADA, S. Glucocorticoids inhibit the expression of an inducible, but not the constitutive, nitric oxide synthase in vascular endothelial cells. Proc Natl Acad Sci USA, v.87, n.24, p.10043-7, Dec. 1990.

178. RALSTON, S.H. Nitric oxide and bone: what a gas! Br J Rheumatol, v.36, n.8, p.831-8, Aug. 1997.

179. RAMAMURTHY, N.S. et al. Inhibition of matrix metalloproteinase-mediated periodontal bone loss in rats: a comparison of 6 chemically modified 
tetracyclines. J Periodontol, v.73, n.7, p.726-34, July 2002.

180. RAMOS, C.D. et al. Neutrophil migration induced by IL-8-activated mast cells is mediated by CINC-1. Cytokine, v.21, n.5, p.214-23, Mar. 2003.

181. REDDI, K. et al. Comparison of the osteolytic activity of surface-associated proteins of bacteria implicated in periodontal disease. Oral Dis, v.1, n.1, p.26-31, Mar. 1995.

182. RNase FREE DNase SET. Disponível em : http://www1.qiagen.com/literature/handbooks/PDF/RNAStabilization AndPurification/FromAnimalAndPlantTissuesBacteriaYeastAndFungi/R NY_Rnase_Free_Dnase/1024108_RNYDNASEProt_0403WW.pdf. $\quad$ Acesso em 25 mar. 2005.

183. ROBINSON, L.P.; DE MARCO, T.J. Alteration of mast cell densities in experimentally inflamed human gingivae. J Periodontol, v.43, n.10, p.61422, Oct. 1972.

184. ROBINSON, M.; HART, D.; PIGOTT, G.H. The effects of diet on the incidence of periodontitis in rats. Lab Anim, v.25, n.3, p.247-53, July 1991.

185. RODINI, C.O.; BATISTA A.C.; LARA V.S. Comparative immunohistochemical study of the presence of mast cells in apical granulomas and periapical cysts: possible role of mast cells in the course of human periapical lesions. Oral Surg Oral Med Oral Pathol, v.97, n.1, p.59-63, Jan. 2004.

186. ROVIN, S. et al. The influence of bacteria and irritation in the initiation of periodontal disease in germfree and conventional rats. J Periodont Res, v.1, n.3, p.193-203, May - June 1966.

187. RYAN, M.E.; RAMAMURTHY, N.S.; GOLUB, L.M. Matrix metalloproteinases and their inhibition in periodontal treatment. Curr Opin Periodontol, v.3, p.85-96, 1996.

188. RYAN, M.E.; GOLUB, L.M. Modulation of matrix metalloproteinase activities in periodontitis as a treatment strategy. Periodontol 2000, v.24, n.1, p.22638, Oct. 2000.

189. RYDER, M.I. Histological and ultrastructural characteristics of the periodontal syndrome in the rice rat. I. General light microscopic observations and ultrastructural observations of initial inflammatory changes. J Periodont 
Res, v.15, n.5, p.502-15, Sept. 1980.

190. SALLAY, K. et al. Bacterial invasion of oral tissues of immunosuppressed rats. Infect Immun, v.43, n.3, p.1091-4, Mar. 1984.

191. SAMEJIMA, Y.; EBISU, S.; OKADA, H. Effect of infection with Eikenella corrodens on the progression of ligature-induced periodontitis in rats. $\mathbf{J}$ Periodont Res, v.25, n.5, p.308-15, Sept. 1990.

192. SANDERS, L.A. et al. Human immunoglobulin G (IgG) Fc receptor IIA (CD32) polymorphism and IgG2-mediated bacterial phagocytosis by neutrophils. Infect Immun, v.63, n.1, p.73-81, Jan. 1995.

193. SANTOS, J.M. Mastócitos nas gengivites crônicas do homem. Belo Horizonte, 1961. 58p. Tese (Livre Docência) - Faculdade de Odontologia e Farmácia, Universidade de Minas Gerais.

194. SANTOS, C.F. et al. Molecular cloning and sequencing of the cDNA for rat mesenteric arterial bed elastase-2, an angiotensin II-forming enzyme. J Cardiovasc Pharmacol, v.39, n.5, p.628-35, May 2002.

195. SCAREL-CAMINAGA, R.M. et al. Interleukin 10 gene promoter polymorphisms are associated with chronic periodontitis. J Clin Periodontol, v.31, n.6, p.443-48, June 2004.

196. SCHROEDER, H.E.; LINDHE, J. Conversion of stable established gingivitis in the dog into destructive periodontitis. Archs Oral Biol, v.20, n.12, p.775-82, Dec. 1975.

197. SCHROEDER, H. The junctional epithelium. Origin, structure and significance. Acta Med Dent Helv, v.1, p.155-67, 1996.

198. SEYMOUR, G.J.; POWELL, R.N.; DAVIES, W.I. Conversion of a stable T-cell lesion to a progressive B-cell lesion in the pathogenesis of chronic inflammatory periodontal disease: an hypothesis. J Clin Periodontol, v.6, n.5, p.267-77, Oct. 1979.

199. SHAPIRA, L. et al. Experimental stress suppresses recruitment of macrophages but enhanced their P. gingivalis LPS- stimulated secretion of nitric oxide. J Periodont, v.71, n.3, p.476-479, Mar. 2000.

200. SHAPIRO, S.; ULMANSKY, M.; SCHEUER, M. Mast cell population in gingiva affected by chronic destructive periodontal disease. J Periodontol, v.40, n.5, 
p.276-8, May 1969.

201. SHIMADA, Y. et al. Association of tumor necrosis factor receptor type $2+587$ gene polymorphism with severe chronic periodontitis. J Clin Periodontol, v.31, n.6, p. 463-9, June 2004.

202. SICHER, H.; WEINMANN, J.P. Bone growth and physiologic tooth movement. Am J Orthod, v.46, p.109-32, 1944.

203. SKOKOS, D. et al. Mast cell-dependent B and T lymphocyte activation is mediated by the secretion of immunologically active exosomes. J Immunol, v.166, n.2, p.868-76,Jan. 2001.

204. SMITH, T.J.; DUCHARME, L.A.; WEIS, J.H. Preferential expression of interleukin-12 or interleukin-4 by murine bone marrow mast cells derived in mast cell growth factor or interleukin-3. Eur J Immunol, v.24, n.4, p.8226, Apr. 1994.

205. SMITH, P.C. et al. In situ detection of matrix metalloproteinase-9 (MMP-9) in gingival epithelium in human periodontal disease. J Periodont Res, v.39, n.2, p.87-92, Apr. 2004.

206. SOCRANSKY, S.S. et al. New concepts of destructive periodontal disease. J Clin Periodontol, v.11, n.1, p.21-32, Jan. 1984.

207. SODEK, J. OVERALL, C. Matrix metalloproteinases in periodontal tissue remodeling. Matrix, v.8, p.352-62, 1992. Supplement.

208. SOELL, M.; ELKAIM, R.; TENEBAUM, H. Cathepsin C, matrix metalloproteinases, and their tissue inhibitors in gingiva and gingival crevicular fluid from periodontitis-affected patients. J Dent Res, v.81, n.3, p.174-8, Mar. 2002.

209. SORSA, T. et al. Comparison of interstitial collagenases from human gingival, sulcular fluid and polymorphonuclear leukocytes. J Periodont Res, v.23, n.6, p.386-93, Nov. 1988.

210. SORSA, T. et al. Identification of proteases from potent periodontopathogenic bacteria as activators of latent human neutrophil and fibroblast-type intersticial collagenases. Infect Immun, v.60, n.11, p.4491-5, Nov. 1992.

211. SORSA, T. et al. Effects of tetracyclines on neutrophil, gingival and salivary collagenases. Ann NY Acad Sci, v.732, p.112-31, Sept. 1994. 
212. SORSA, T. et al. Cellular source, activation and inhibition of dental plaque collagenase. J Clin Periodontol, v.22, n.9, p.709-17, Sept. 1995.

213. SORSA, T. et al. Functional sites of chemically modified tetracycline (CMTs): inhibition of the oxidative activation oh human neutrophils and chicken osteoclast pro-matrix metalloproteinases. J Reumathol, v.25, n.5, p.975-82, May 1998.

214. SORSA, T.; TJADERHANE, L.; SALO, T. Matrix metalloproteinases (MMPs) in oral diseases. Oral Dis, v.10, n.6, p.311-8, Nov. 2004.

215. SOUZA, M.A.L. A morphometric and histological study on the development and eruption of the rat mandibular first molar. New castle, 1991. 164p. Dissertação (Mestrado) - University of Newcastle upon Tyne.

216. STEFANIVIC-RACIC, M. et al. The role of nitric oxide in proteoglycan turnover by bovine articular cartilage organ cultures. J Immunol, v.156, n.3, p.121320, Feb. 1996.

217. STEINSVOLL, S.; HELGELAND, K.; SCHENCK, K. Mast cells - a role in periodontal diseases? J Clin Peridontol, v.31, n.6, p.413-9, June 2004.

218. STOUFI, E.D. et al. Phenotypic analyses of mononuclear cells recovered from healthy and diseased human periodontal tissues. J Clin Immunol, v.7, n.3, p.235-45, May 1987.

219. SUZUMURA, Y. et al. Long junctional epithelium produced by application of bacterial protease in rats. J Periodont Res, v.24, n.3, p.217-21, May 1989.

220. TASKIRAN, D. et al. Nitric oxide mediates suppression of cartilage proteoglycan synthesis by interleukin-1. Biochem Biophys Res Commun, v.200, n.1, p.142-8, Apr. 1994.

221. TAUBMAN, M.A. et al. Phenotypic studies of cells from periodontal disease tissue. J Periodont Res, v.19, n.6, p.537-90, Nov. - Dec. 1984.

222. TENG, Y.T.; SODEK, J.; McCULLOCH, C.A.G. Gingival crevicular fluid gelatinase and its relationship to periodontal disease in human subjects. J Periodont Res, v.27, n.5, p.544-52, Sept. 1992.

223. UITTO, V.J. et al. A protease of Bacteriodes gingivalis degrades cell surface and matrix glycoproteins of cultured gingival fibroblasts and induces secretion of collagenase and plasminogen activator. Infect Immun, v.57, n.1, p.213-8, 
Jan. 1989.

224. UITTO, V.J.; OVERALL, C.M.; McCULLOCH, C. Proteolytic host cell enzymes in gingival crevice fluid. Periodontol 2000, v.31, n.1, p.77-104, Feb. 2003.

225. VALDERHAUG, J.; ZANDER, HA. Relationship of "epithelial rests of Malassez" to other periodontal structures. Periodontics, v.5, n.5, p.254-8, Sept. - Oct. 1967.

226. VAN DER ZEE, E.; EVERTS, V.; BEERTSEN W. Cytokine modulate routes of collagen breakdown. Review with special emphasis on mechanisms of collagen degradation in the periodontium and the burst hypothesis of periodontal disease progression. J Clin Periodontol, v.24, n.5, p.297-305, May 1997.

227. VIGNERY, A.; BARON, R. Dynamic histomorphometry of alveolar bone remodeling in the adult rat. Anat Rec, v.196, n.2, p.191-200, Feb. 1980.

228. VILLA, I. et al. Capacity of mouse mast cells to prime $\mathrm{T}$ cells and to induce specific antibody responses in vivo. Immunol, v.102, n.2, p.165-72, Feb. 2001.

229. WALSH, L.J. et al. Relationship between mast cell degranulation and inflammation in the oral cavity. J Oral Pathol Med, v.24, n.6, p.266-72, July 1995.

230. WEINBERG, M.A.; BRAL, M. Laboratory animal models in periodontology. J Clin Periodontol, v.26, n.6, p.335-40, June 1999.

231. WELLE, M. Development, significance, and heterogeneity of mast cells with particular regard to the mast cell-specific proteases chymase and tryptase. $\mathbf{J}$ Leukoc Biol, v.61, n.3, p.233-45, Mar. 1997.

232. WERB, Z. ECM and cell surface proteolysis: regulating cellular ecology. Cell, v.91, n.4, p.439-42, Nov. 1997.

233. WIEBE, S.H. et al. Osteoclast activation in inflammatory periodontal diseases. Oral Dis, v.2, n.2, p.167-80, June 1996.

234. WILliAMS, R.C. Periodontal disease. N Engl J Med, v.322, n.6, p.373-82, Feb. 1990.

235. WILSON, M.; REDDI, K.; HENDERSON, B. Cytokine-inducing components of periodontopathogenic bacteria. J Periodont Res, v.31, n.6, p.393-407, Aug. 1996. 
236. ZACHRISSON, B.U.; SCHULZ-HAUDT, S.D. Biologically active substances of the mast cell. J Periodont Res, v.2, p.21-35, 1967.

237. ZACHRISSON, B.U. Mast cells of the human gingiva. II. Methacromatic cells at low $\mathrm{pH}$ in healthy and inflamed tissue. J Periodont Res, v.2, p. 87-89, 1967.

238. ZADEH, H.H.; NICHOLS, F.C.; MIYASAKI, K.T. The role of cell-mediated immune response to Actinobacillus actinomycetemcomitans and Porphyromonas gingivalis in periodontitis. Periodontol 2000, v.20, p.239-88, June 1999.

239. ZHAO Z.Z. et al. Mast cell/T cell interactions in oral lichen planus. J Oral Pathol Med, v.31, n.4, p.189-95, Apr. 2002. 


\begin{abstract}
Inflammatory periodontal disease envolves imunopathological and inflammatory mechanisms against bacterial dental plaque, including the participation of host resident as well as inflammatory cells and chemical mediators. The present work characterized a ligature-induced model of experimental inflammatory periodontal disease, emphasysing clinical and microscopic valuation as well as quantitative study of the number of mast cells and the presence of expression of mesanger RNA (mRNA) of inducible nitric oxide (iNOS) and metalloproteinases (MMPs) -2 and -9. Samples were obtained from different periods and microscopically analysed trough hematoxylin-eonin and toluidin blue stainings, and quantitatively estimated through Reverse Transcriptase Polimerase Chain Reaction (RT-PCR). The results revealed the presence of numerous polymorphonuclear (PMN) cells on tissues affected by inflammatory periodontal disease, mainly on initial periods. Significant expression of MMP-9 was still detected on tissues affected by inflammatory periodontal disease on day 3 and 7, with no significant difference on the expression of MMP-2. iNOs expression was also higher on diseased tissues compared to controls on day 3 and between days 3 and 7 diseased tissues themselves. Mast cells numbers were reduced on the dentogengival area of diseased tissues compared to controle ones, on buccal and ligual sides. Our results suggest that experimentally induced inflammatory periodontal disease are characterized by inflammatory lesions with the predominance of PMNs and bone resorption areas since the first day of induction, although without a progression to a lymphocyte / plasma cells inflammatory infiltrate characteristic of human disease. Probably, MMP-9 and iNOS participate on the evolution and pathogenesis of ligature-induced periodontal disease, including tissue destruction and alveolar bone resorption. On the other hand, mast cells seem no to be a significant source of iNOS and MMP-9.
\end{abstract}

